\title{
MASTER
}

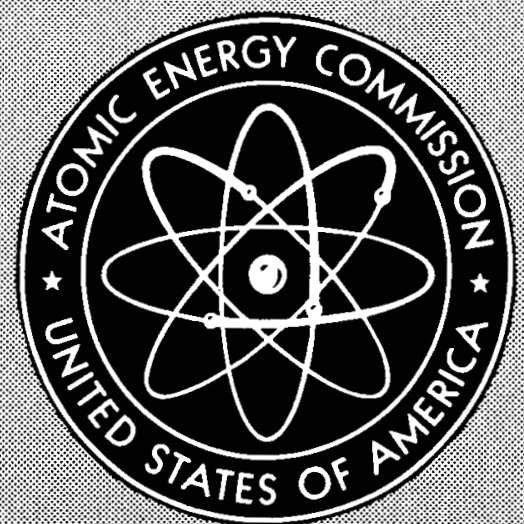

GA-2289

\section{THE DEVELOPMENT AND EVALUATION OF GRAPHITE- MATRIX FUEL COMPACTS FOR THE HTGR}

By

Walter V. Goeddel

August 8, 1961

General Atomic Division

General Dynamics Corporation

San Diego, California 


\section{DISCLAIMER}

This report was prepared as an account of work sponsored by an agency of the United States Government. Neither the United States Government nor any agency Thereof, nor any of their employees, makes any warranty, express or implied, or assumes any legal liability or responsibility for the accuracy, completeness, or usefulness of any information, apparatus, product, or process disclosed, or represents that its use would not infringe privately owned rights. Reference herein to any specific commercial product, process, or service by trade name, trademark, manufacturer, or otherwise does not necessarily constitute or imply its endorsement, recommendation, or favoring by the United States Government or any agency thereof. The views and opinions of authors expressed herein do not necessarily state or reflect those of the United States Government or any agency thereof. 


\section{DISCLAIMER}

Portions of this document may be illegible in electronic image products. Images are produced from the best available original document. 


\section{LEGAL NOTICE}

This report was prepared as an account of Government sponsored work. Neither the United States, nor the Commission, nor any person acting on behalf of the Commission:

A. Makes any warranty or representation, expressed or implied, with respect to the accuracy, completeness, or usefulness of the information contained in this report, or that the use of any information, apparatus, method, or process disclosed in this report may not infringe privately owned rights; or

B. Assumes any liabilities with respect to the use of, or for damages resulting from the use of any information, apparatus, method, or process disclosed in this report.

As used in the above, "person acting on behalf of the Commission" includes any employee or contractor of the Commission, or employee of such contractor, to the extent that such employee or contractor of the Commission, or employee of such contractor prepares, disseminates, or provides access to, any information pursuant to his employment or contract with the Commission, or his employment with such contractor.

This report has been reproduced directly from the best available copy.

Printed in USA. Price $\$ 2.25$. Available from the Office of Technical Services, Department of Commerce, Washington 25, D. C. 


\section{GENERAL ATOMIC}

DIVISION OF

\section{GENERAL DYNAMICS}

JOHN JAY HOPKINS LABORATORY FOR PURE AND APPLIED SCIENCE

P.O. BOX 6O8. SAN DIEGO 12. CALIFORNIA

GA-2289

METALS, CERAMICS, AND MATERIALS

THE DEVELOPMENT AND EVALUATION OF GRAPHITE-MATRIX

FUEL COMPACTS FOR THE HTGR

Work done by:

F. Carpenter

G. Engle

W. Goeddel

W. Godsin

J. Pontelandolfo

R. Pyle

J. Shoffner
Report written by:

Walter V. Goeddel

U. S. Atomic Energy Commission

Contract $\operatorname{AT}(04-3)-314$

August 8, 1961 
A summary of the development and evaluation of graphite-matrix fuel compacts for the High-temperature Gas-cooled Reactor (HTGR)is presented. These fuel compacts consist of thorium-uranium dicarbide particles dispersed in a high-density graphite matrix and are produced by a hot-pressing process. Detailed experimental studies of fuel-compact properties with relation to method of preparation, starting fuel materials, and fuel concentration showed that satisfactory fuel compacts containing up to $40 \mathrm{wt}-\%$ fuel $(\mathrm{Th}+\mathrm{U})$ could be prepared. Compacts prepared from thorium-uranium oxide, thorium-uranium silicide, and thorium-uranium dicarbide coated with pyrolytic carbon were subjected to radiation and fission-productretention testing and other evaluations.

Typical properties of these graphite-matrix, dispersion-fuel compacts include graphite density, 1.90 to $1.95 \mathrm{~g} / \mathrm{cm}^{3}$; crushing strength, $8500 \mathrm{psi}$; the rmal conductivity at $2000^{\circ} \mathrm{C}, 0.07 \mathrm{cal} / \mathrm{cm}^{2}-\mathrm{sec} /{ }^{\circ} \mathrm{C} / \mathrm{cm}$; and permeability, $2 \times 10^{-3} \mathrm{~cm}^{2} / \mathrm{sec}$. Extensive radiation testing showed these compacts to be dimensionally and structurally stable after burnups of $6.9 \times 10^{19}$ fissions $/ \mathrm{cm}^{3}\left(60 \%\right.$ of HTGR design) at $1100^{\circ}$ to $1500^{\circ} \mathrm{C}$. Compacts containing thorium-uranium dicarbide particles coated with pyrolytic carbon showed continuing fission-product holdup times of several hundred hours after a burnup of $5.4 \times 10^{19}$ fissions $/ \mathrm{cm}^{3}$ at $1500^{\circ}$ to $1900^{\circ} \mathrm{C}$. Results of the radiation and fission-product-retention testing of compacts and fuel materials are discussed in detail. 
CONTENTS

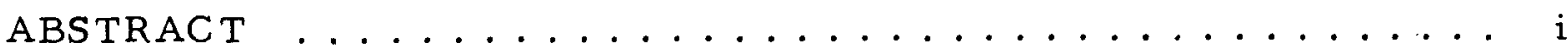

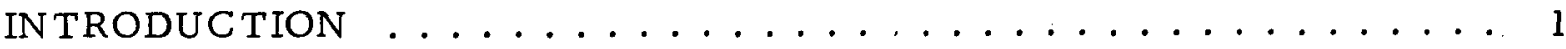

FUEL-COMPACT DESIGN AND DEVELOPMENT . . . . . . . . . 5

Fuel-compact Development .................. 6

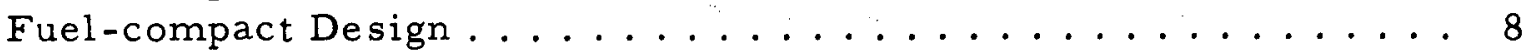

PREPARATION OF COMPACTS BY HOT-PRESSING TECHNIQUES . . 11

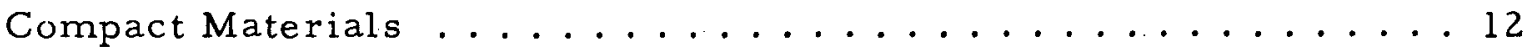

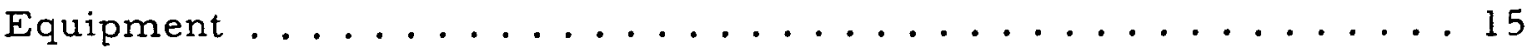

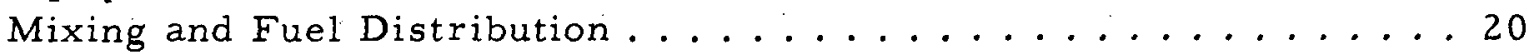

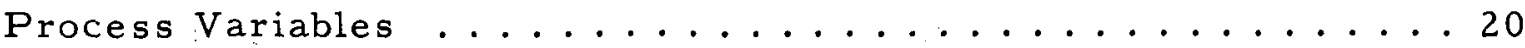

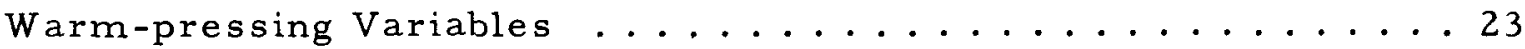

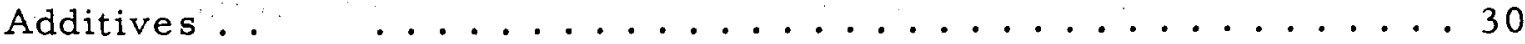

SUMMARY OF HOT-PRESSING TECHNIQUES . . . . . . . . . . . 30

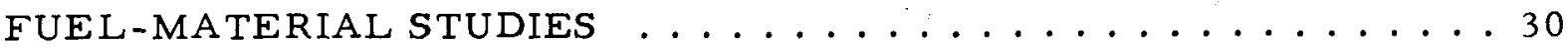

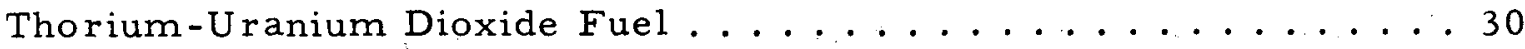

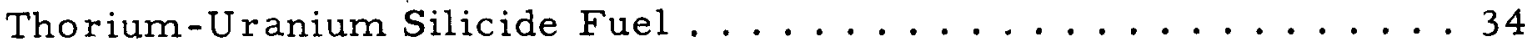

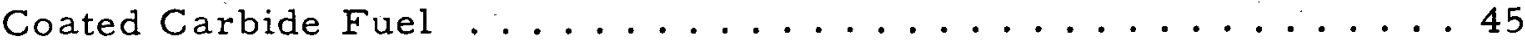

PROPERTIES OF W ARM-PRESSED AND SINTERED GRAPHITE -

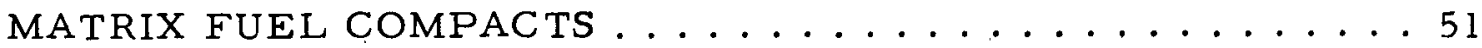

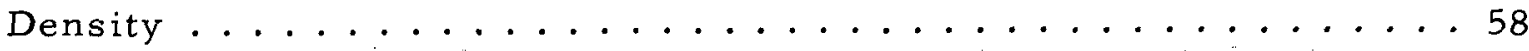

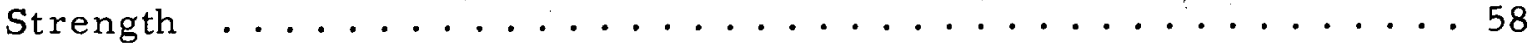

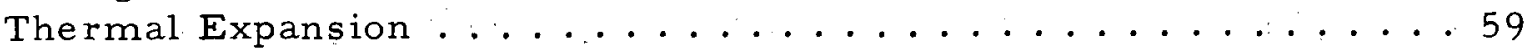

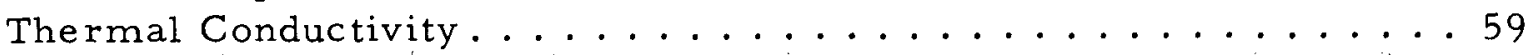

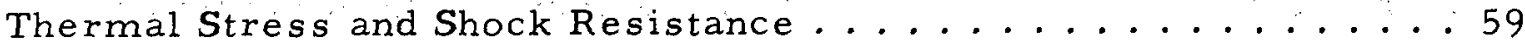

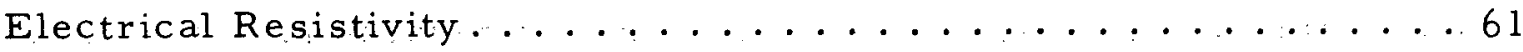

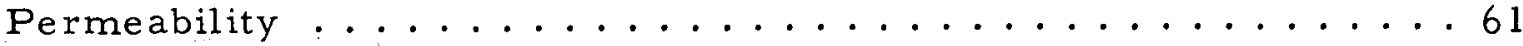

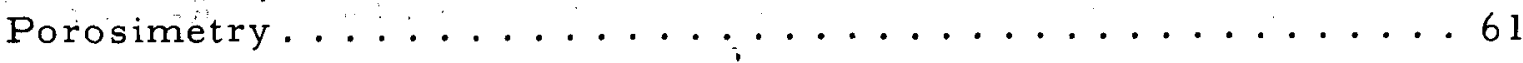

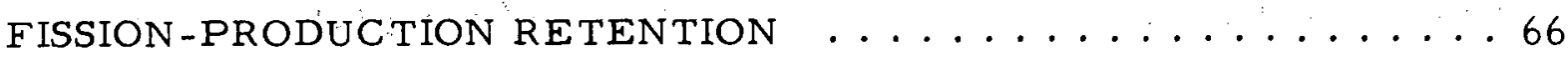

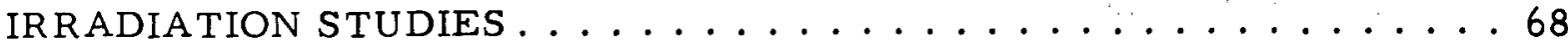

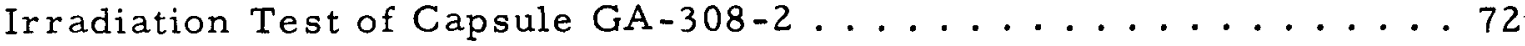

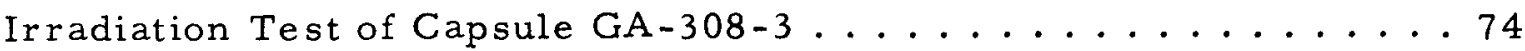

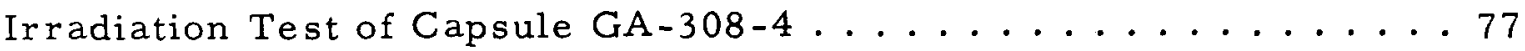

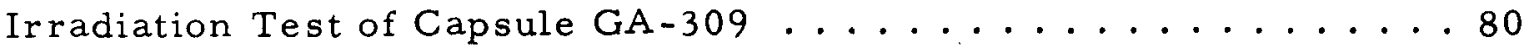

High-burnup Irradiation Test of Capsule GA-113.........884 


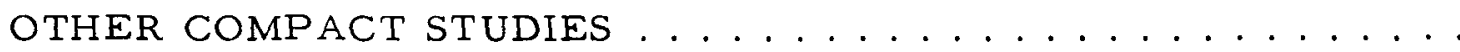

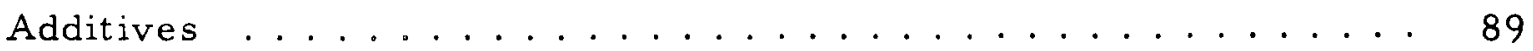

Graphite-matrix Control-rod Bodies .............. 91

ACKNOWLEDGMENTS . . . . . . . . . . . . . . . . . . . 92

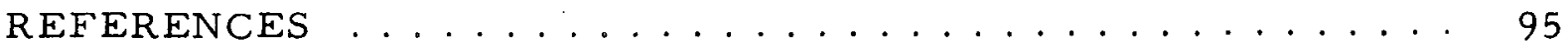

Figures

1. Isometric view of the high-temperature, gas-cooled,

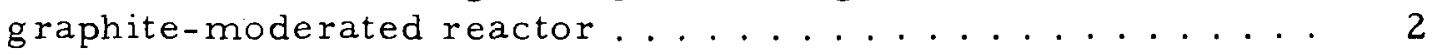

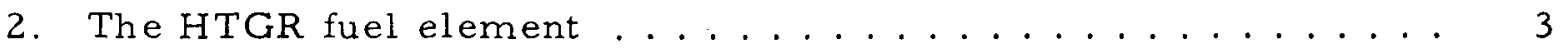

3. Variation of Matrix volume subject to fission-fragment damage with $\mathrm{ThC}_{2}-\mathrm{UC}_{2}$ concentration for various fuel-particle sizes. 7

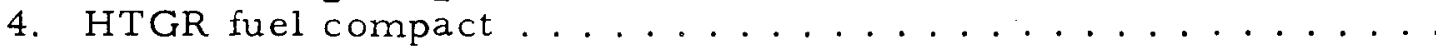

5. Compacts prepared by coated carbide process: (a) 3/8-in. - thick annulus, (b) $5 / 8$-in. -thick annulus ............... 10

6. Cold-press die and punches used for making annular compacts . 16

7. Warm press used in making solid fuel compacts ......... 17

8. Warm press used in making annular fuel compacts ....... 18

9. High-temperature sintering furnace ............. 19

10. Radiographs of slices from fuel compacts showing uniform

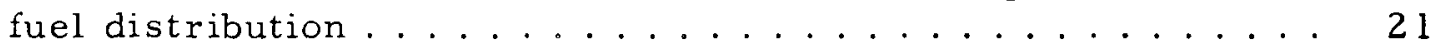

11. Variation of compact density and crushing strength with size

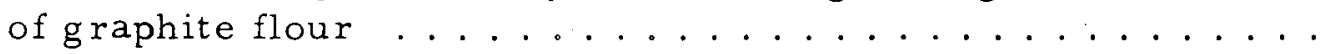

12. Variation of density and crushing strength of compacts prepared from AGOT graphite flour with pitch content . . . . 24

13. Variation of density and crushing strength of compacts prepared from GP-38 graphite flour with pitch content . . . . .

14. Variation of density and crushing strength of compacts prepared from AGOT graphite flour with warm-pressing

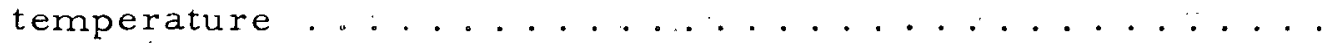

15. Variation of density and crushing strength of compacts prepared from GP-38 graphite flour with warm-pressing

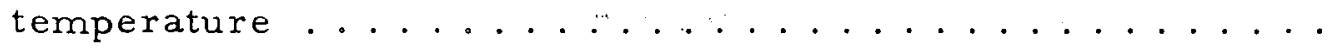

16. Variation of compact density with cold- and warm-compacting

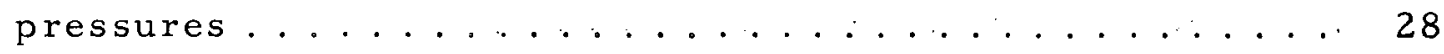

17. Density of compacts-versus cold-compacting pressure and

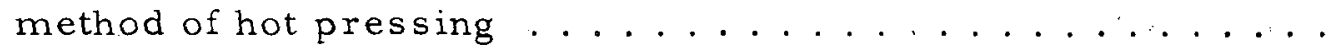

18. Variation of compact density and crushing strength with ethyl cellulose content ... $\therefore . \ldots . . . \ldots \ldots$

19. Variation of compact density and crushing strength with

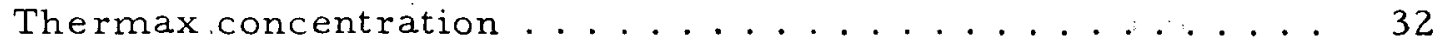

20. Photomic rograph of (Th; U) $\mathrm{O}_{2}$ fuel particles .......... 35

21. Photomicrograph of $(\mathrm{Th}, \mathrm{U}) \mathrm{C}_{2}$ fuel particles formed by in situ conversion of $(\mathrm{Th}, \mathrm{U}) \mathrm{O}_{2}$ particles during fuel-compact fabrication 
22. Variation of fuel-compact density with metal ( $T h+U)$ content for compacts prepared from $(\mathrm{Th}, \mathrm{U}) \mathrm{O}_{2} \ldots \ldots . \ldots 36$

23. Drawing of fuel compact prepared by converted-oxide process . 37

24. Fuel-compact density versus metal $(\mathrm{Th}+U)$ content for compacts prepared from Th-U-Si ............. 41

25. Photomicrograph of Th-U-Si (7. 4\% Si, Th: U $=5: 2)$ arc

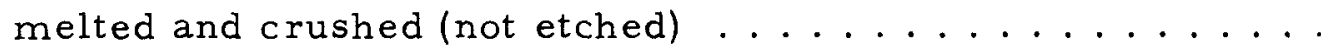

26. Photomicrographs of Th-U-Si (7.4\% Si, Th:U = 5:2) prepared by arc melting (etched with $\mathrm{HNO}_{3}, \mathrm{HF}, \mathrm{H}_{2} \mathrm{O}$ ) ..........

27. Photomicrographs of $\mathrm{ThC}_{2}-\mathrm{UC}_{2}-\mathrm{SiC}$ fuel particles in a graphite-matrix fuel compact formed by in situ conversion of Th-U-Si particles (7. $4 \% \mathrm{Si}$, Th: $\mathrm{U}=5: 2$ )

28. Vapor pressure of silicon, uranium, zirconium, thorium,

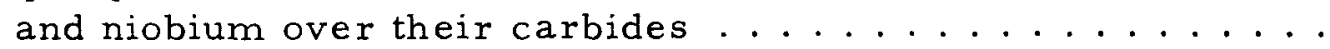

29. Weight losses from arc-melted and crushed $\mathrm{ThC}_{2}-\mathrm{UC}_{2}-\mathrm{SiC}$ fuel after heating at $2000^{\circ} \mathrm{C}$ in vacuo as a function of the addition of various amounts of $\mathrm{ZrC}$ and $\mathrm{NbC} \ldots \ldots$

30. Schematic diagram of apparatus for the preparation of carbon-coated $\mathrm{UC}_{2} \ldots \ldots \ldots \ldots$

31. Photomicrographs of pyrolytic-carbon-coated (Th, $U) \mathrm{C}_{2}$ fuel particles; coating deposited from acetylene at $1400^{\circ} \mathrm{C} . .50$

32. Fuel-compact fabrication processes .............. 52

33. Weight and dimensional changes resulting from sintering of warm-pressed, annular fuel compacts at various tempera-

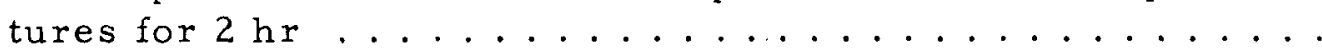

34. Sectioned fuel compact containing carbon-coated ( Th, $U) \mathrm{C}_{2}$

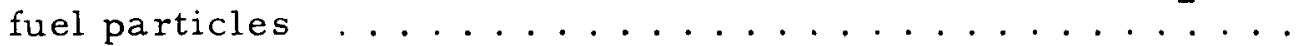

35. Pyrolytic-carbon-coated ( $\mathrm{Th}, \mathrm{U}) \mathrm{C}_{2}$ particle in graphite matrix.

36. Annular fuel compacts containing carbon-coated ( $\mathrm{Th}, \mathrm{U}) \mathrm{C}_{2}$

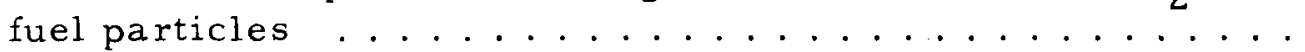

37. Annular fuel compact containing carbon-coated ( $\mathrm{Th}, \mathrm{U}) \mathrm{C}_{2}$

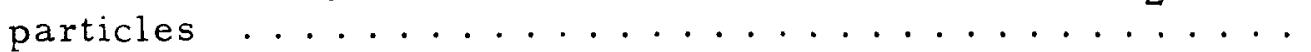

38. Electric (resistance) heating apparatus for measuring thermal conductivity of graphite specimens .............

39. Permeability versus density of graphite-matrix material for the HTGR fuel compacts ................

40. Pore spectrum of warm-pressed and sintered graphite

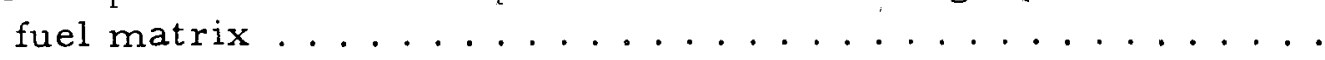

41. Pore spectrum of warm-pressed and sintered graphite fuel

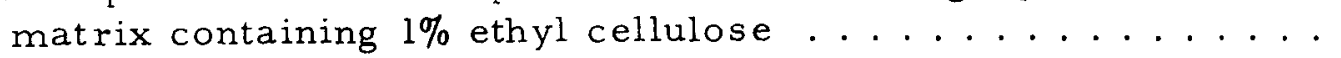

42. Photomicrograph of warm-pressed and sintered graphite

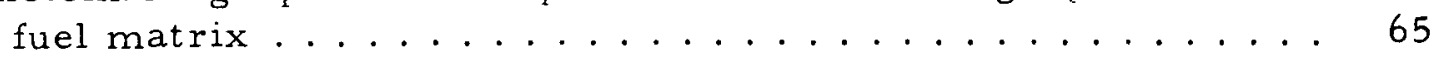

43. Release of $\mathrm{Xe}^{133}$ from compacts with coated and uncoated fuel particles at indicated test temperatures ......... 69

44. Irradiation capsule GA-308 ... . . . . . . . . . . . . 70

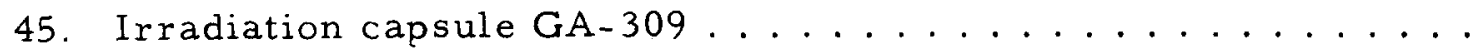


46. Compacts from capsule GA-308-2 after irradiation to $4.25 \times 10^{19}$ fissions $/ \mathrm{cm}^{3}$ at $1050^{\circ}$ to $1200^{\circ} \mathrm{C} \ldots \ldots$

47. Fuel compact of the type prepared for the irradiation

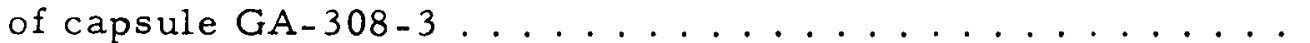

48. Fuel compacts from capsule GA-308-3 after irradiation to $6.9 \times 10^{19}$ fissions $/ \mathrm{cm}^{3}$ at $1150^{\circ}$ to $1480^{\circ} \mathrm{C} \ldots \ldots$

49. Fuel compacts from capsule GA-308-4 after irradiation to $6 \times 10^{19}$ fissions $/ \mathrm{cm}^{3}$ at $1090^{\circ}$ to $1480^{\circ} \mathrm{C} \ldots \ldots \ldots$

50. Pyrolytic-carbon-coated $(\mathrm{Th}, \mathrm{U}) \mathrm{C}_{2}$ fuel particles prepared for GA-309-4, -5 , and -6 capsule irradiations; coatings deposited from acetylene at $1400^{\circ} \mathrm{C} \ldots \ldots \ldots$

51. Fuel compacts containing pyrolytic-carbon-coated ( $\mathrm{Th}, \mathrm{U}) \mathrm{C}_{2}$ fuel particles typical of those prepared for the GA-309-4, -5 , and -6 and GA-309-7, -8 , and -9 capsule irradiations ..

52. Pyrolytic-carbon-coated ( $\mathrm{Th}, \mathrm{U}) \mathrm{C}_{2}$ fuel particles prepared for irradiation of capsule GA-309-9; coating was deposited from acetylene at $1400^{\circ} \mathrm{C} \ldots \ldots \ldots$

53. Pyrolytic-carbon-coated ( $T h, U) C_{2}$ fuel particle typical of those prepared for irradiation of capsule GA-309-8;

coating was deposited from methane at $1400^{\circ} \mathrm{C}$

54. Thinly coated ( Th, $\mathrm{U}) \mathrm{C}_{2}$ fuel particles prepared for irradiation of capsule GA-309-7; 10- $\mu$ coating deposited from acetylene at $1400^{\circ} \mathrm{C}$

55. Variation of compact density with concentration of metallic additive

56. Density versus boron content for $\mathrm{B}_{4} \mathrm{C}$-graphite control-rod compacts prepared by the warm-press and sinter process . .

57. Crushing strength versus boron content for $\mathrm{B}_{4} \mathrm{C}-\mathrm{g}$ raphite control-rod compacts prepared by the warm-press and sinter process

Tables

1. HTGR Fuel-compact Parameters ................ 6

2. Properties of Pitch Samples Evaluated for HTGR Fuel Compacts .......................... 13

3. Properties of Compacts Prepared from Various Pitch Samples . 14

4. Result of Ignition Analysis, for Fuel Distribution . . . . . . . . 23

5. X-ray Diffraction Analysis of Mixtures of (Th, U) $\mathrm{O}_{2}-(\mathrm{Th}, \mathrm{U}) \mathrm{C}_{2} \quad{ } \quad 33$

6. X-ray Analyses of Thorium-Uranium Silicides .......... 39

7. Vapor Pressures of Silicon over Various Carbide Mixtures at $2000^{\circ} \mathrm{C} \ldots \ldots \ldots \ldots . \ldots \ldots$

8. Typical Properties of Graphite-matrix Fuel Compacts . . . . . 58

9. Xe ${ }^{133}$ Loss from Fuel Compacts with Uncoated Fuel Particles . 67

10. Fuel-compact Compositions and Dimensions for GA-308

Capsule Irradiations ................... 71

11. Burnups and Temperatures of Irradiation for GA-308 and

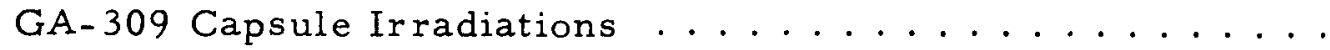


12. Dimensional Changes of Fuel Compacts from Irradiation of Capsule GA-308-2 ...................... 74

13. Dimensional Changes of Fuel Compacts from Irradiation of Capsule GA-308-3 ..................... 77

14. Dimensional Changes of Fuel Compacts from Irradiation of Capsule GA-308-4 ..................... 78

15. Fuel Loadings and Compact Dimensions for Capsules GA-309-4, -5 , and $-6 \ldots \ldots$. . . . . . . . . . 1

16. Krypton and Xenon Release Data for Capsule GA-309-4 . . . 85

17. Krypton and Xenon Release Data for Capsule GA-309-5 .... 85

18. Krypton and Xenon Release Data for Capsule GA-309-6 .... 85

19. Properties of Compacts Prepared with Silicon, Niobium, and Zirconium Additives ................ 89

20. Boron Loadings and Atom Ratios of $\mathrm{B}_{4} \mathrm{C}$-Graphite Compacts . . 91 


\section{INTRODUCTION}

The High-temperature Gas-cooled Reactor (HTGR) is a helium-cooled, graphite-moderated, solid-homogeneous fueled type of reactor in which the high-temperature potentialities of gas cooling with high power density are combined with a fuel capable of high burnup. $(1,2,3)^{*}$ The HTGR prototype plant is being designed to produce $1000^{\circ} \mathrm{F}$ steam at $1450 \mathrm{psi}$ and to have a net capacity of $40 \mathrm{Mw}(\mathrm{e})$. Fuel temperatures and gas pressures for this prototype plant will be approximately the same as those required for larger plants.

The general arrangement of the reactor is shown in Fig. 1. The reactor core is made up of 855 cylindrical elements, approximately 40 of which are control rods, arranged in a closely packed equilateral triangular array. The coolant gas passes through the tricusp-shaped passages formed by the cylindrical elements.

The fuel element (see Fig. 2) consists of a low-permeability graphite can containing the fuel compacts and a portion of both the top and bottom reflectors. The fuel element is encased in a concentric sleeve of lowpermeability graphite that is joined to the graphite end reflector sections. The space between the graphite sleeve and the graphite can is purged by helium flowing through it. The helium then flows back down the element through the space between the fuel compacts and the graphite can, through the internal fission-product trap, and then to an external fission-product trapping system. The element is $12 \mathrm{ft}$ long and $3.5 \mathrm{in}$. in diameter. The fuel compacts consist of fuel $\left(\mathrm{U}^{235}\right)$ and fertile material $\left(\mathrm{Th}^{232}\right)$ in the form of carbides dispersed in a graphite matrix. The composition of the fuel compacts is about 1 atom of $U^{235}$ to 10 atoms of thorium to 700 atoms of carbon.

Carbides of uranium and thorium are employed for the fissile-fertile

\footnotetext{
References are listed at the end of this report.
} 


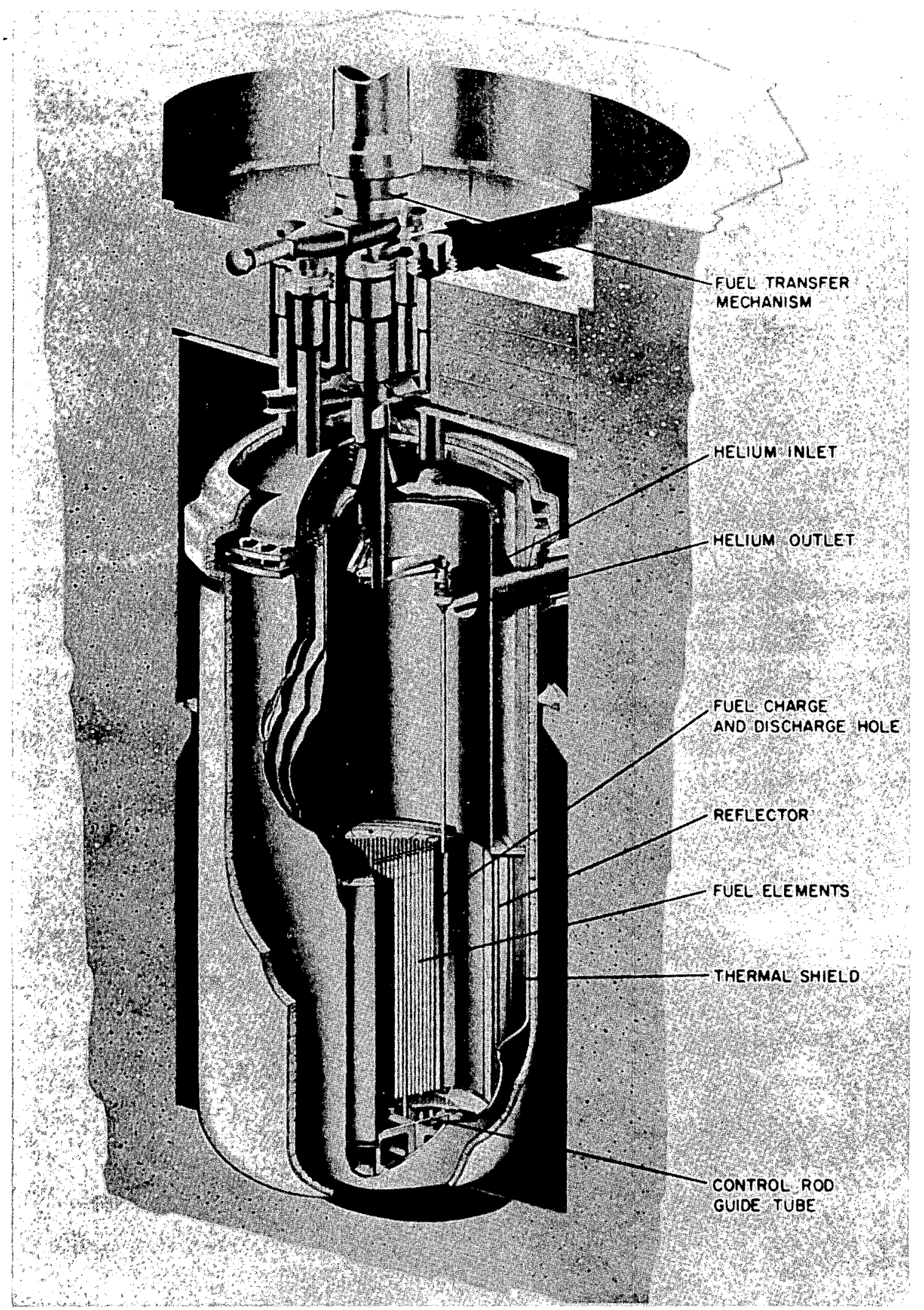

Fig. 1--Isometric view of the high-temperature, gas-cooled, graphite-moderated reactor 

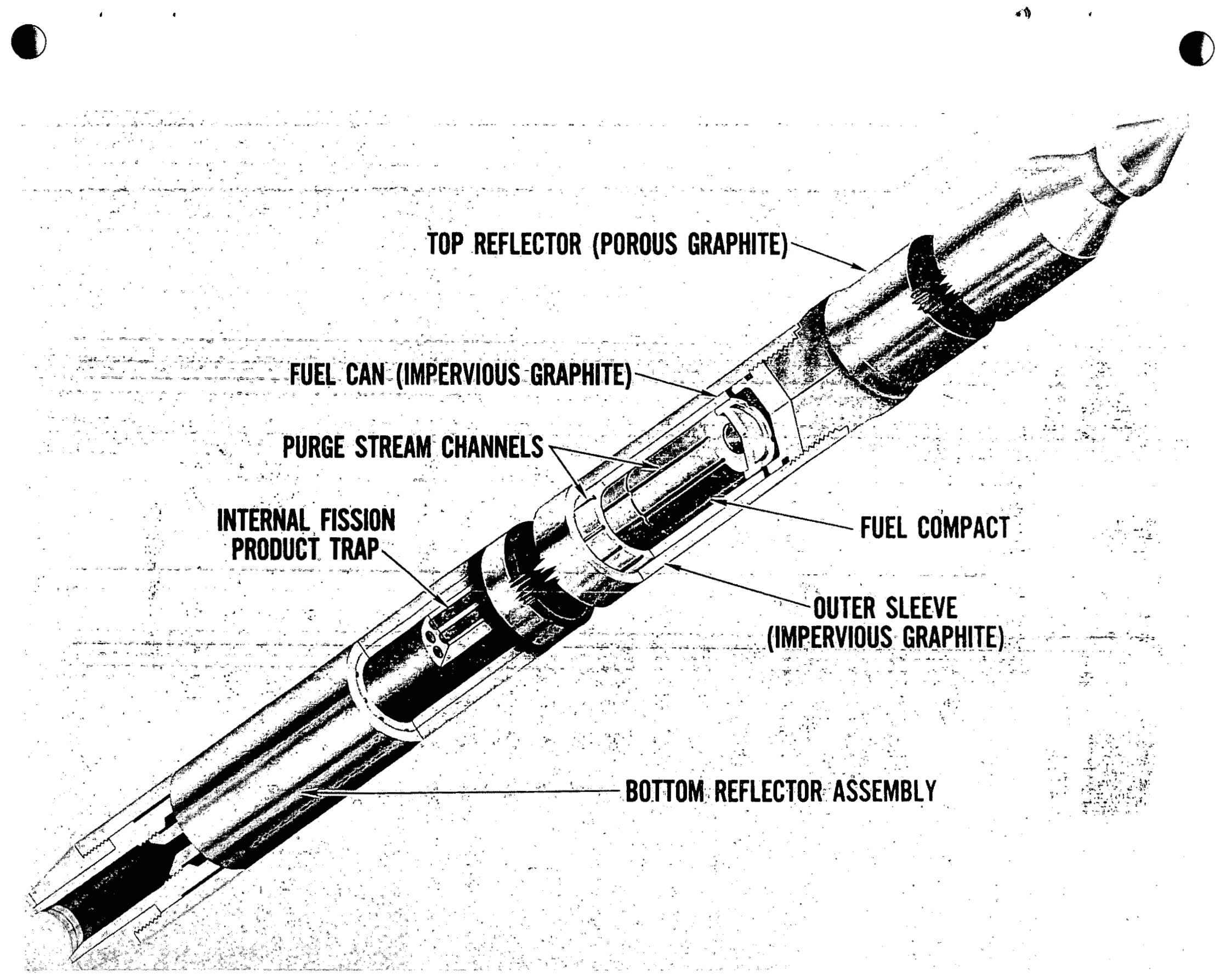
phase because, at the operating temperature of the fuel, they are thermodynamically stable. Because of the high $U^{235}$ burnup expected (approximately 0.6 fission per initial fissile atom for the $40-\mathrm{Mw}(\mathrm{e})$ prototype to about 2 for larger plants), the fuel and fertile material are mixed to avoid a large change in power distribution during core burnout. In addition, mixing of fuel and fertile material results in a useful contribution to the prompt negative temperature coefficient from Doppler broadening of the thorium resonance.

The arrangement of fissile-fertile particles in a graphite matrix is most desirable when the mean distance between the particles is larger than the range of fission-fragment recoil. Most of the graphite matrix of the fuel compact is thus free from fission-fragment damage, and the remaining continuous web of undamaged matrix material retains many of its desirable preir radiation properties.

The HTGR fuel-compact development program, begun in the fall of 1957, is discussed in this report. Initially, the program was a modest effort in which several approaches were investigated. During the past two years, however, there has been a more intensive effort that has culminated in the warm-pressing process for the fabrication of fuel compacts. Detailed experimental studies of fuel-compact properties with relation to methods of preparation, starting fuel materials, and fuel concentration are reported. Also, scale-up studies are described in which full-sized HTGR fuel compacts were produced with pilot-scale equipment.

Fission-product retention, dimensional and structural stability under irradiation, thermal conductivity, and other properties of the fuel compacts have also been studied, and the results are reported herein. Also discussed are the preparation of thorium-uranium dicarbide particles coated with pyrolytic carbon and the incorporation of the se coated particles into graphitematrix fuel compacts. 


\section{FUEL-COMPACT DESIGN AND DEVELOPMENT}

The performance requirements placed on the fuel compacts by the HTGR design are summarized as follows:

1. Spatial Fixation of Fuel. The fissile-fertile phases must remain fixed with in the graphite matrix; i.e., they must not migrate or evaporate at the elevated operating temperature of the HTGR.

2. Transfer of Heat at Desired Temperatures. Good hightemperature thermal conductivity and thermal-stress resistance are required to accommodate the high HTGR power densities and to permit the removal of heat without undue thermal gradients.

3. Mechanical and Dimensional Stability. The fuel compacts must retain their integrity and remain dimensionally stable under prolonged high-temperature irradiation.

4. Retention of Fission Products. Fission products must be retained within the fuel compacts as long as possible to minimize the load on the fission-product trapping system.

5. Low Cost. Low fuel costs, of course, constitute an important requirement for all commercial power-reactor programs.

More specific compositional and operational parameters are summarized in Table 1.

Although graphite, among conventional fuel-element materials, offered the best combination of high-temperature physical, mechanical, thermal, and nuclear properties, it had two serious shortcomings for this application: (1) the porosity of graphite would readily permit the fission products to escape, and (2) there was no satisfactory method for incorporating the necessary thorium and uranium into a graphite fuel body. These were the principal problems to be solved in the HTGR fuel-element development program. 
Table 1

HTGR FUEL-COMPACT PARAMETERS

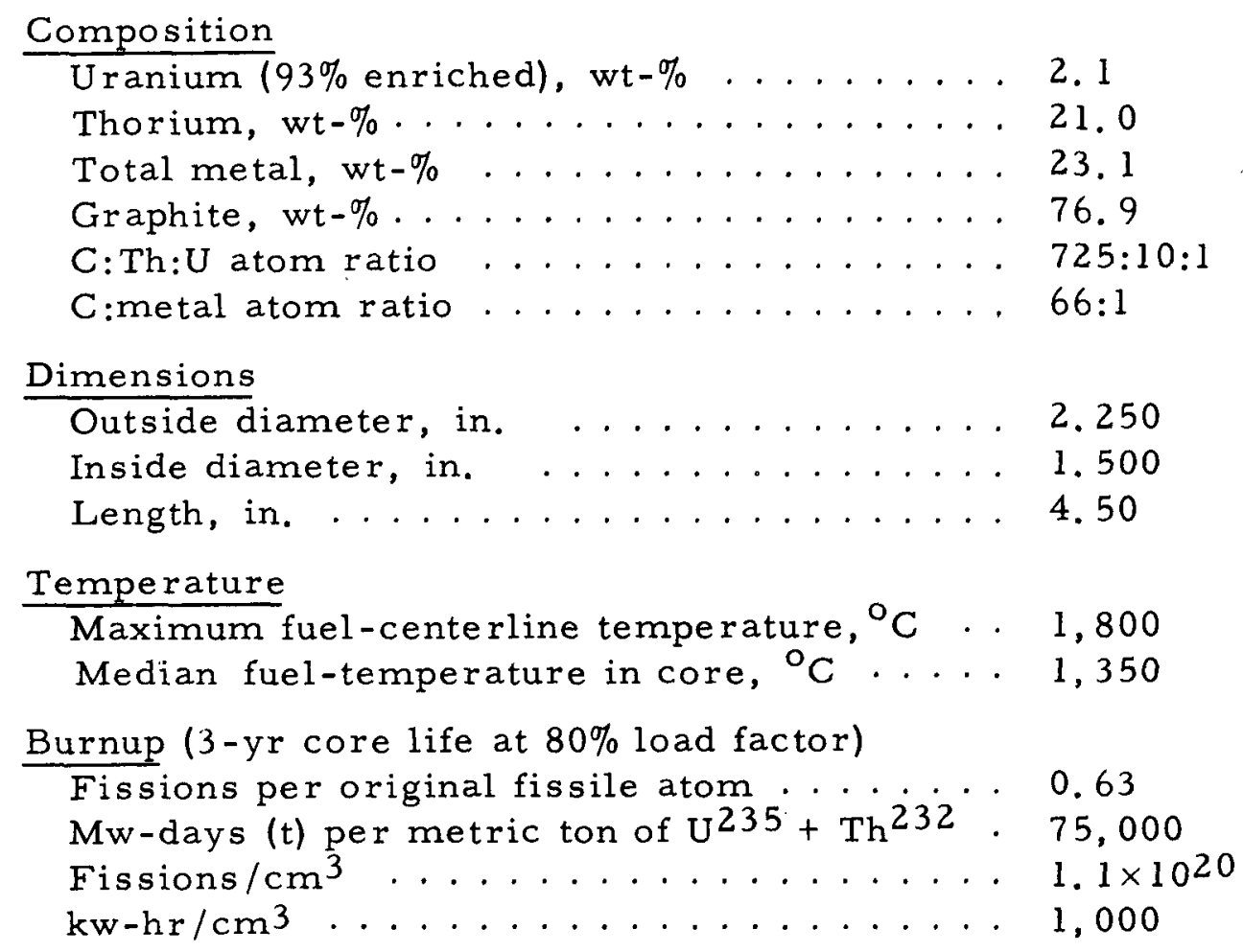

Fuel-compact Development

Incorporation of uranium in graphite by impregnation with aqueous solutions results in uranium carbide particles of such extremely small size that fission-recoil damage to the surrounding graphite and fission-product release are unnecessarily high. The effect of fuel-particle size and fuel loading on the portion of graphite matrix subjected to fission-fragment damage may be seen in Fig. 3 (the curves were calculated for HTGR conditions from Harrison's data ${ }^{(4)}$ ). Matrix damage increases rapidly as the fuel-particle size drops below $100 \mu$.

Since discrete fuel particles of $100 \mu$ or larger were required for the HTGR fuel compacts and since they had to be uniformly dispersed in the graphite matrix, the admixture approach was chosen for this work. Also, the size, dimension, and property requirements imposed on the fuel compacts 


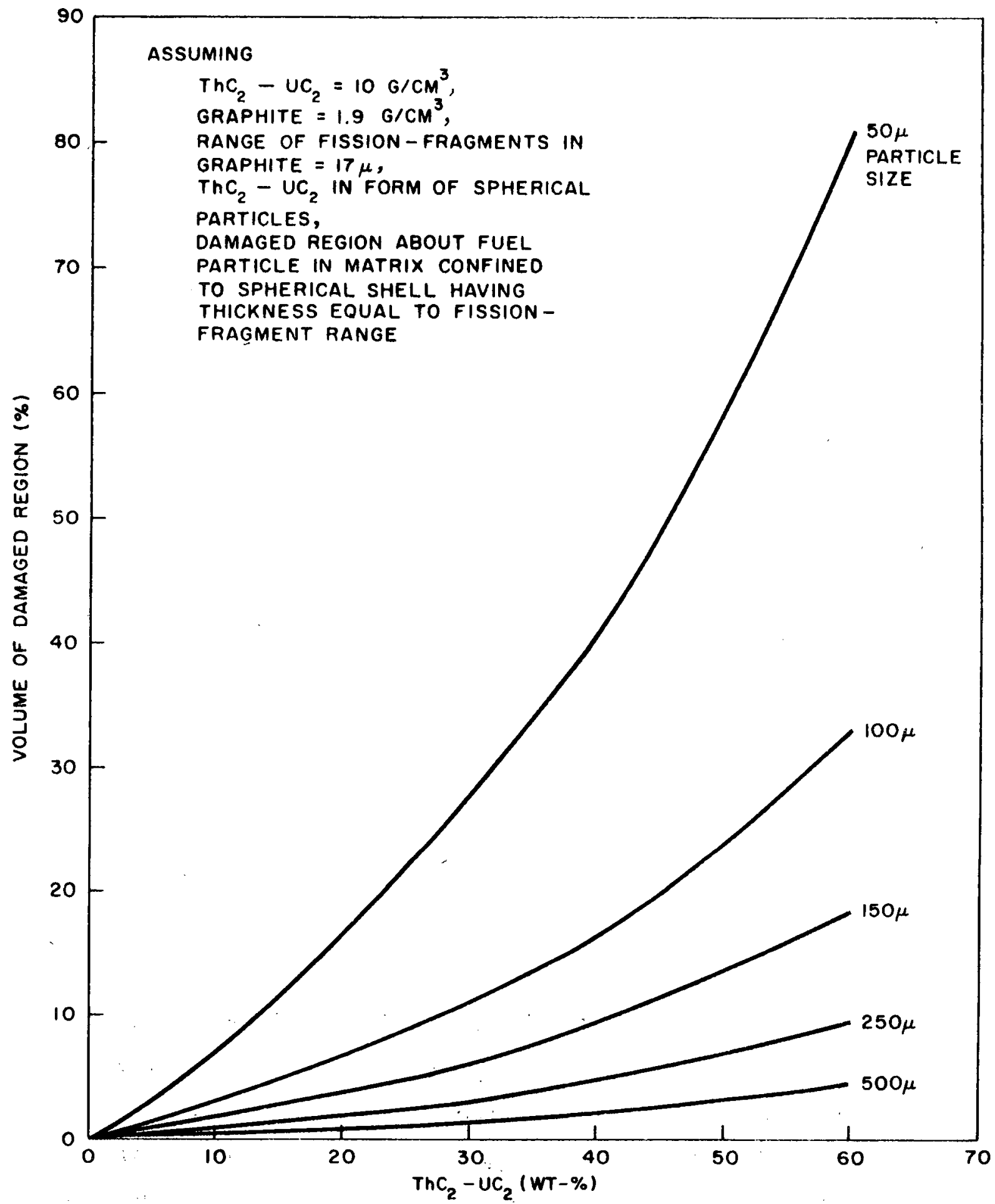

Fig. 3--Variation of matrix volume subject to fission-fragment damage with $\mathrm{ThC}_{2}-\mathrm{UC}_{2}$ concentration for various fuel-particle sizes 
by the HTGR design indicated that a molding process would offer several advantages over an extrusion process--namely, higher density and hence (it was hoped) lower permeability, higher thermal conductivity, and greater strength; closer dimensional control; and better adaptability to short lengths. Solid-solution thorium dioxide-uranium dioxide, ( $T h U) \mathrm{O}_{2}$, fuel particles were selected for the initial work, and it was planned to convert them in situ to solid-solution thorium dicarbide-uranium dicarbide, $(\mathrm{Th}, \mathrm{U}) \mathrm{C}_{2}$, by suitable heat treatment of the molded graphite compacts.

During the first stage of the development program, ( Th, U) $\mathrm{O}_{2}$ particles were mixed with graphite powder and pitch, compacted cold, and sintered at $2100^{\circ} \mathrm{C}$ to convert the oxides to carbides. This conventional ceramic technique did not yield satisfactory compacts; densities and strengths were low, dimensional control was poor, and sintering times had to be prolonged to avoid bubbling of the pitch. Studies with other binders and varying processing conditions yielded no worthwhile improvement, and this approach was abandoned in favor of hot-pressing techniques.

Hot-pressing, wherein the elevated temperature curing and bonding of the pitch takes place while the compact is tightly secured in a die to prevent expansion, not only produces denser and stronger bodies but also produces them more rapidly and with less binder. Furthermore, compaction in the die prevents distortion during carbonization of the binder and thereby permits the attainment of very close dimensional tolerances.

Fuel-compact Design

Previously, the fuel-compact design for the HTGR was similar to that shown in Fig. 4, a composite annular design wherein the fuel was dispersed in the ring and the burnable poison in the center rod. Recently, the process has been shifted toward ring compacts, as shown in Fig. 5. These rings, which are approximately $1-1 / 8$ in. long, contain the fuel; they are slipped over a central rod, or spine, of graphite in the fuel element. Such an arrangement offers several advantages from a production viewpoint: speed and uniformity of production are improved; dimensional tolerances 

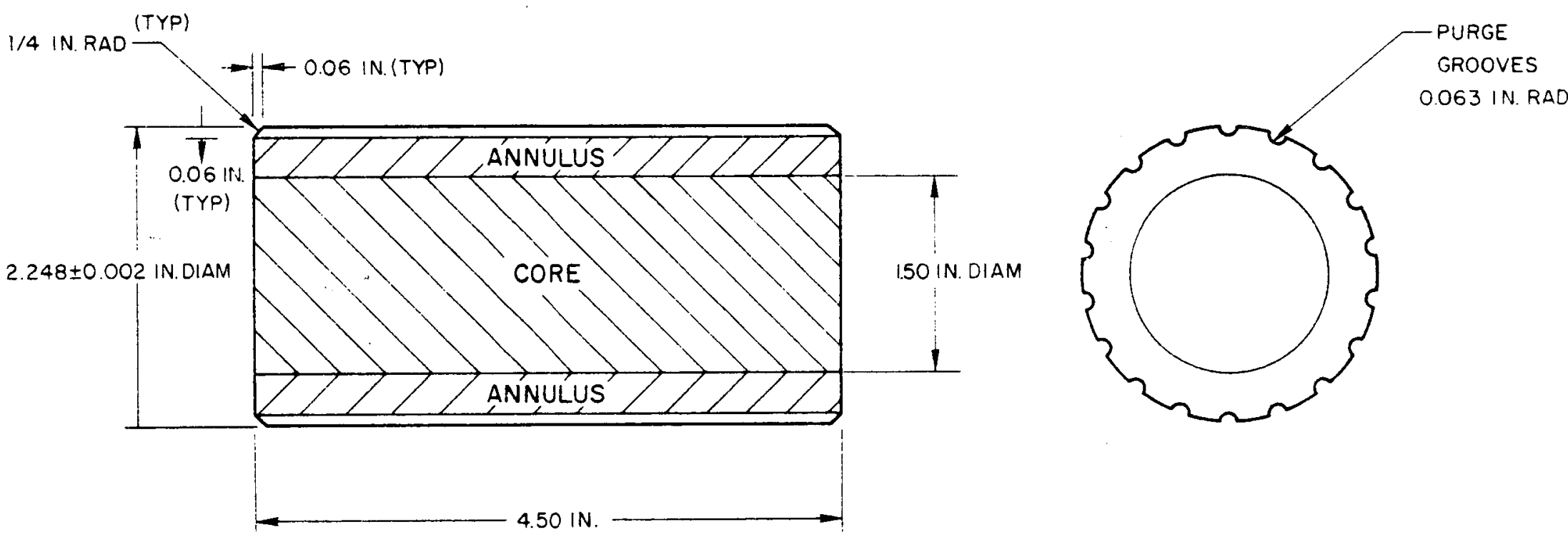

Fig. 4--HTGR cylindrical fuel compact 

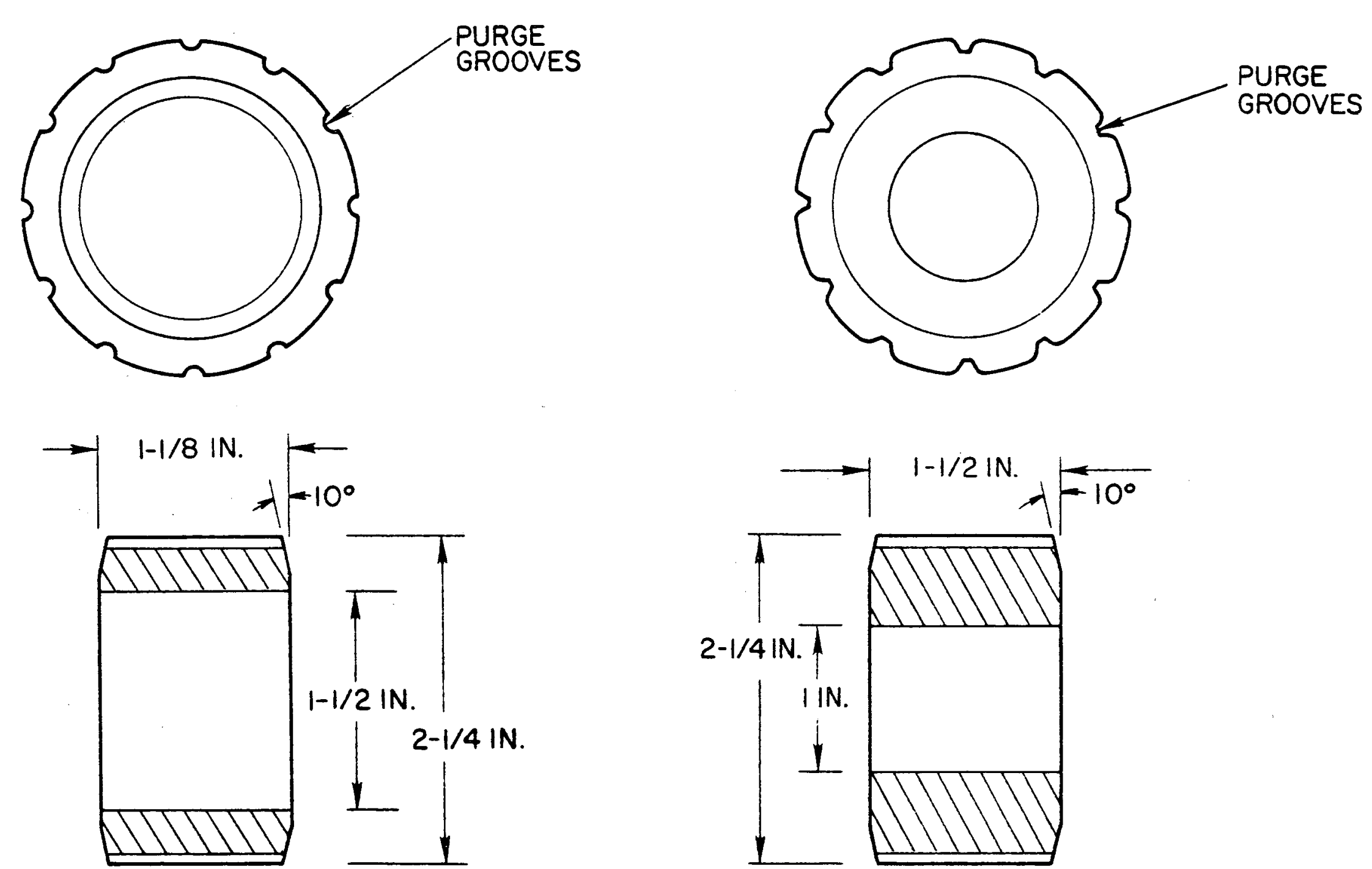

(a)

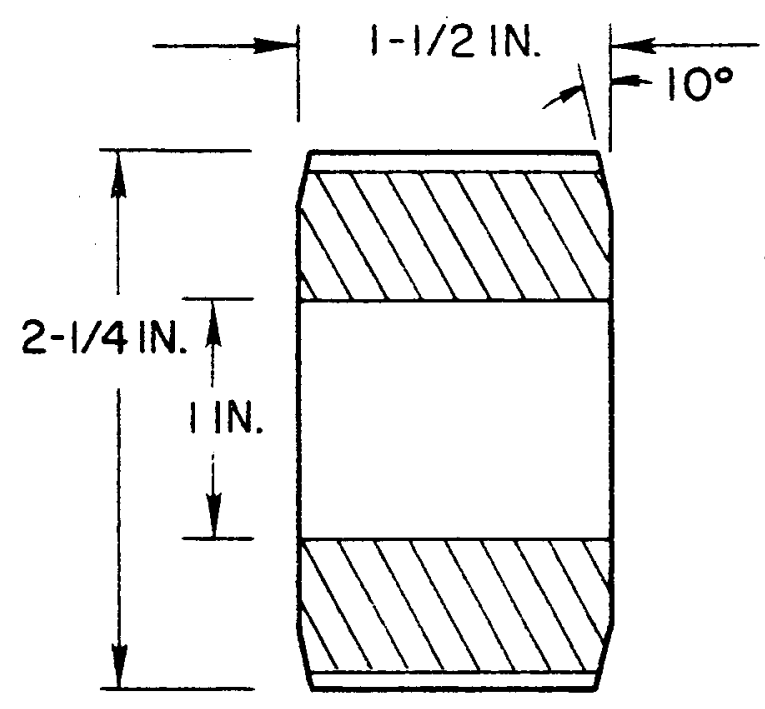

(b)

Fig. 5--Ring compacts prepared by coated carbide process: (a) 3/8-in. -thick annulus, (b) 5/8-in. -thick annulus 
are better; fuel and poison are not combined, thereby making the recovery of scrap easier; purge grooves are readily molded in during warm-pressing; and coated carbide particles are more readily accommodated. Both ends of the compact are bevelled to allow an unimpeded flow of the purge gas without the necessity of aligning the purge grooves.

For much of the laboratory-scale development work, cyclindrical compacts 1 in. in diameter by 1 to $2 \mathrm{in.}$ long were studied. Numerous compacts of each design we re produced, the process details of which are discussed in the following section.

\section{PREPARATION OF COMPACTS BY HOT-PRESSING TECHNIQUES}

The fuel compacts are prepared by mixing the fissile-fertile-phase particles with graphite and pitch and then hot-pressing the material to form a dense, strong compact. By using graphite powder for the filler and only a small amount $(10 \mathrm{wt}-\%)$ of pitch binder, good thermal properties are obtained without taking the bodies to graphitizing temperatures. Also, the hot-press technique produces compacts of high density and good strength. and permits the use of substantially less binder than do conventional graphite fabricating techniques. (Only $10 \mathrm{wt}-\%$ pitch binder is required and after warm-pressing half of it remains, leaving a high-density matrix of $95 \%$ graphite and 5\% carbon.)

Two types of hot-pressing procedures have been investigated:

1. Resistance Hot-pressing. This process combines the baking operation and the conversion of the oxide fuel to carbide in a single step. The mixture of fuel. graphite, and binder is compacted and heated to from $2100^{\circ}$ to $2200^{\circ} \mathrm{C}$ by resistance heating with high currents. Since the compacts are internally heated, the dies may be strengthened by external, watercooled metal jackets, and high compacting pressures can be used. There are, however, numerous problems associated with this process: (1) there is a lack of die materials with sufficient strength and chemical inertness (carbon and graphite are the most suitable, but they creep rapidly at these 
temperatures); (2) there is difficulty in obtaining uniform and reproducible temperatures owing to current bypass and resistivity changes in the die materials; and (3) prolonged times are required to remove gases (primarily CO) from the compact while it is tightly confined in the die. This approach was therefore replaced by a two-step process.

2. Warm-pressing and Sintering. In this approach, the baking of the binder and the shaping of the compact are accomplished by pressing at $1000^{\circ} \mathrm{C}$ or below. The oxide fuel is then converted to the carbide form by heating the compact in a separate vacuum furnace. This basic process, termed the warm-press and sinter process, has been found to be the most suitable method for preparing HTGR fuel compacts:

\section{Compact Materials}

Graphite Flour. In order to obtain the desirable properties of a graphite matrix without the need of heat-treating the fuel bodies to graphitizing temperatures, graphite flour was selected instead of carbon or coke as the starting material for the matrix. Commercial graphite was ground to powder, sieved, and used for much of the initial work. Subsequently, National Carbon Company graphite powder (grade GP-38), a manufactured rather than a natural graphite, was selected because of its low ash and boron content, fine particle size, and availability. Natural graphites were tried in early work, but they produced compacts that were weaker in compression tests and more anisotropic than those made from synthetic graphites. The GP-38 used is $98 \%$ minus $-200-$ mesh material with an average particle size (estimated) of less than $20 \mu$.

Binder. Pitch, the traditional binder in the carbon and graphite industries, has proven satisfactory in making fuel bodies. The initial work was performed using pitch supplied by Portland Gas and Coke Company, Gasco No. 2387. The quality of this pitch was very satisfactory but the supply was not, so several other pitches were evaluated to select a successor. Melting points, purities, coking values, and solubilities were compared (see Table 2), and compacts prepared from each pitch were 
Table 2

PROPERTIES OF PITCH SAMPLES EVALUATED FOR HTGR FUEL COMPACTS

\begin{tabular}{|c|c|c|c|c|c|c|c|c|c|}
\hline \multirow[b]{2}{*}{$\begin{array}{c}\text { Pitch } \\
\text { Identification }^{\text {a }}\end{array}$} & \multirow{2}{*}{$\begin{array}{c}\text { Melting } \\
\text { Point } \\
\left({ }^{\circ} \mathrm{C}\right)\end{array}$} & \multirow[b]{2}{*}{$\begin{array}{l}\text { Ash } \\
(w t-\%)\end{array}$} & \multirow{2}{*}{$\begin{array}{c}\text { Boron } \\
\text { Content } \\
\text { (ppm) }\end{array}$} & \multirow{2}{*}{$\begin{array}{l}\text { Coking } \\
\text { Value } \\
(w t-\%)\end{array}$} & \multicolumn{5}{|c|}{ Solubility in Various Solvents (wt-\%) } \\
\hline & & & & & Triclene D & $\begin{array}{l}\text { Methylethyl- } \\
\text { ketone }\end{array}$ & Benzene & Quinoline $\mathrm{b}^{\mathrm{b}}$ & Solv G \\
\hline Barrett No. 1 & $71-74$ & 0.044 & $<1 / 2$ & --- & 80 & 58 & 86 & --- & 79 \\
\hline Barrett No. 2 & 93 & 0.16 & $<1 / 2$ & 33.6 & 79 & 61 & 85.5 & 94.8 & 67 \\
\hline Barrett No. 3 & 100 & 0.12 & $<1 / 2$ & 43.4 & 81 & 49 & 70.8 & 87.8 & 44 \\
\hline Barrett No. 4 & 157 & 0.042 & 3 & 44.6 & 61 & 36 & 73 & 94.7 & 12 \\
\hline Barrett No: 30 & 101 & 0.083 & $<1 / 2$ & 55.8 & 51 & 73 & 72.1 & 87.1 & $\mathrm{NS}^{\mathrm{d}}$ \\
\hline Resin "C" & $\ldots$ & 0.071 & $<1 / 2$ & $\ldots$ & 96.5 & 87 & 83 & --- & NS \\
\hline MP 112 & 112 & 0.12 & $N D^{\underline{e}}$ & 58 & 70 & 70 & 66.2 & 88.7 & NS \\
\hline MP 130 & $\sim 130$ & 0.082 & ND & --- & 77 & 68 & 68 & $\ldots$ & 43 \\
\hline MP 150 & $\sim 150$ & 0.11 & ND & $\cdots$ & 76 & 68 & 73 & $-\cdots$ & NS \\
\hline MP 175 & 174 & 0.26 & $\mathrm{ND}$ & 66.7 & 64 & 53 & 39.5 & 84.1 & NS \\
\hline Gasco & 105 & 0.05 & ND & $-\cdots$ & 86 & 38 & 88 & --- & 58 \\
\hline
\end{tabular}

${ }^{a}$ All pitches were supplied by Plastics and Coal Chemicals Division, Allied Chemical Corporation, except Gasco pitch, which was supplied by Portland Gas and Coke Company.

$\underline{\mathrm{b}}$ Values reported by manufacturer.

Spectrographic determination.

d NS indicates less than $10 \%$ solubility.

${ }_{\text {e }}$ D indicates less than 2 ppm. 
evaluated for density, crushing strength, and permeability (see Table 3). Barrett No. 30 medium pitch was selected as the binder, although several of the others would have been satisfactory.

Table 3

PROPERTIES OF COMPACTS PREPARED FROM VARIOUS PITCH SAMPLES

\begin{tabular}{|c|c|c|c|c|c|}
\hline \multirow[b]{2}{*}{ Pitch } & \multirow{2}{*}{$\begin{array}{l}\text { Density } \\
\left(\mathrm{g} / \mathrm{cm}^{3}\right)\end{array}$} & \multicolumn{2}{|c|}{$\begin{array}{c}\text { Crushing Strengtha } \\
\text { (psi) }\end{array}$} & \multicolumn{2}{|c|}{$\begin{array}{c}\text { Helium Permeability } \underline{b} \\
\left(\mathrm{~cm}^{2} / \mathrm{sec}\right)\end{array}$} \\
\hline & & Transverse & Longitudinal ${ }^{\text {c }}$ & $\Delta P=10 \mathrm{~atm}$ & $\Delta P=1$ atm \\
\hline Barrett No. 1 & 1.95 & 9040 & 7830 & $12 \times 10^{-2}$ & $3 \times 10^{-3}$ \\
\hline Barrett No. 2 & 1.94 & 9130 & 7490 & $12 \times 10^{-2}$ & $3 \times 10^{-3}$ \\
\hline Barrett No. 3 & 1.95 & 8600 & 6740 & $17 \times 10^{-2}$ & $4.3 \times 10^{-3}$ \\
\hline Barrett No. 4 & 1.97 & 7450 & 7550 & $8.2 \times 10^{-2}$ & $2 \times 10^{-3}$ \\
\hline Barrett No. 30 & 1.97 & 8530 & 7420 & $8 \times 10^{-2}$ & $2 \times 10^{-3}$ \\
\hline Resin "C" & 1.95 & 8410 & 6560 & $12 \times 10^{-2}$ & $3 \times 10^{-3}$ \\
\hline MP 112 & 1.98 & 9560 & 7310 & $4.5 \times 10^{-2}$ & 1. $1 \times 10^{-3}$ \\
\hline MP 130 & 1.96 & 9200 & 7170 & $8.1 \times 10^{-2}$ & $2 \times 10^{-3}$ \\
\hline MP 150 & 1.97 & 9870 & 8060 & $4.5 \times 10^{-2}$ & 1. $1 \times 10^{-3}$ \\
\hline MP 175 & 1.96 & 9650 & 7790 & $4.5 \times 10^{-2}$ & $1.1 \times 10^{-3}$ \\
\hline Gasco & 1.96 & 8480 & 6800 & $13 \times 10^{-2}$ & $3.3 \times 10^{-3}$ \\
\hline
\end{tabular}

a Determined on specimens 0.25 in. long and 0.25 in. in diameter.

betermined on specimens 1.0 in. in diameter and 0.25 in. thick; helium flow was transverse to grain orientation.

$\frac{c}{d}$ Direction with reference to grain orientation.

${ }^{\mathrm{d}}$ Calculated from values at $\Delta \mathrm{P}=10$ atm by using experimentally determined conversion factor.

Other materials, including furfuryl alcohol, phenol-formaldehyde resin, and sucrose, were investigated as binders for the warm-press and sinter process. None produced compacts with as good physical properties as did pitch. 
Plasticizer and Vehicle. To aid in granulating the fuel mixture, a plasticizer was incorporated in the mix. The plasticizer is ethyl cellulose, grade N-200, manufactured by the Hercules Powder Company.

A liquid phase is used to facilitate mixing and to aid in distributing the pitch. The two most promising vehicles were benzene and trichloroethylene because of their solvency for pitch and their fast evaporation rate. Trichloroethylene (Triclene D manufactured by E. I. Du Pont de Nemours and Company) was selected because of its lower toxicity and flammability.

Fuel. Solid-solution thorium-uranium dioxide, $(\mathrm{Th}, \mathrm{U}) \mathrm{O}_{2}$, thoriumuranium silicides, and solid-solution thorium-uranium dicarbide, (Th, U) ${ }_{2}$, coated with pyrolytic carbon have been used as fuel feed materials in preparing compacts. These three fuels are discussed in later sections of this report.

\section{$\underline{\text { Equipment }}$}

For cold-pressing three-segment dies (see Fig. 6) are used; tool. steel is used for these dies and punches.

For warm-pressing graphite dies and punches are employed. (ATJ, manufactured by National Carbon Company, and HLM, manufactured by Great Lakes Carbon Company, are both satisfactory die and punch materials.) Two heating methods have been employed: (1) external heating by a resistance furnace or induction coil and (2) internal heating by passing heavy currents through the punches and compact. A typical warm-press unit for producing solid cylindrical compacts is shown in Fig. 7, and Fig. 8 illustrates a warm-press unit for producing annular compacts of the HTGR design. The graphite die is reinforced by an external, water-cooled steel jacket.

Vacuum furnaces of the type shown in Fig. 9 are used for sintering or heat-treating the warm-pressed compacts. The heating element is graphite. 


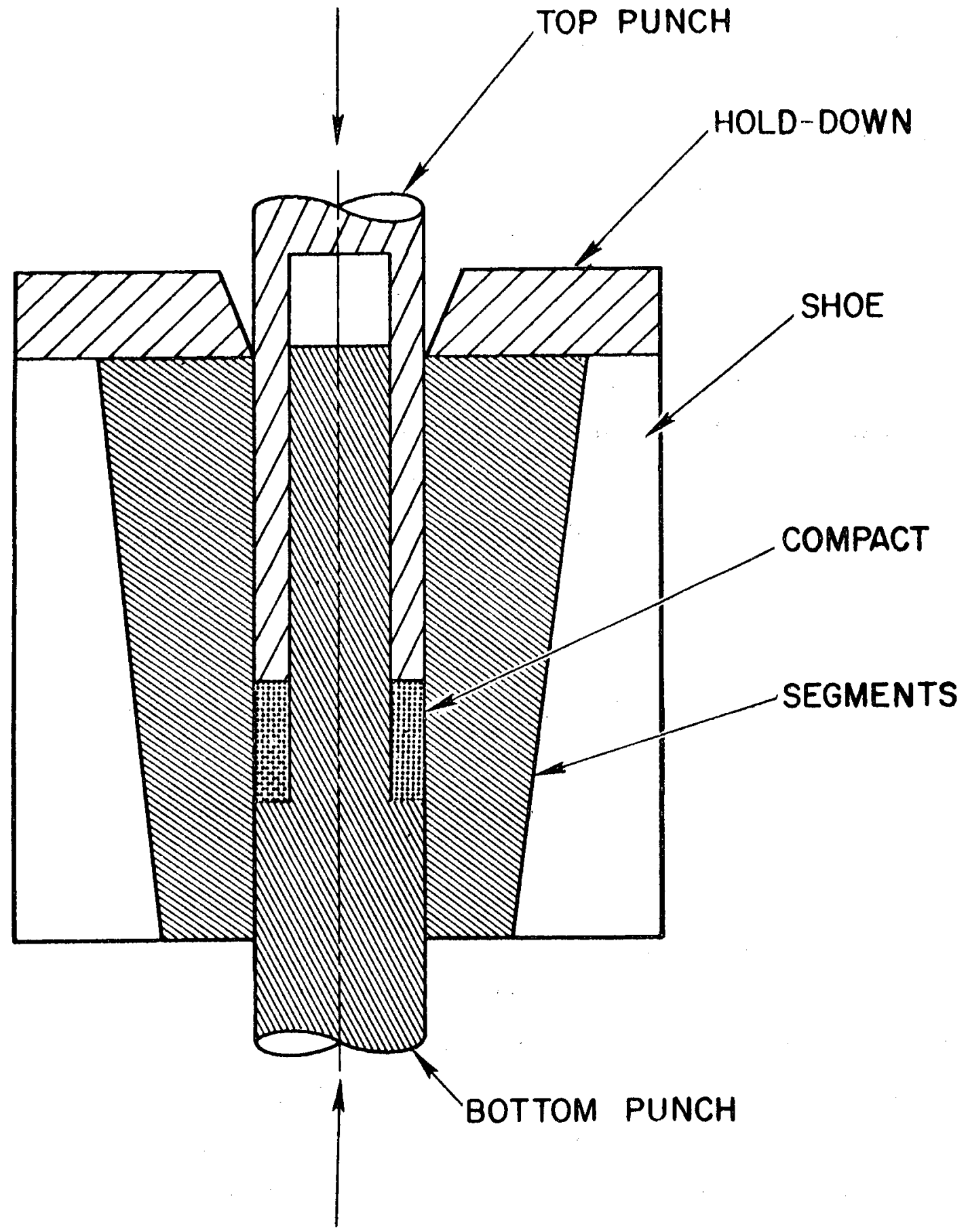

Fig. 6--Cold-press die and punches used for making annular compacts 


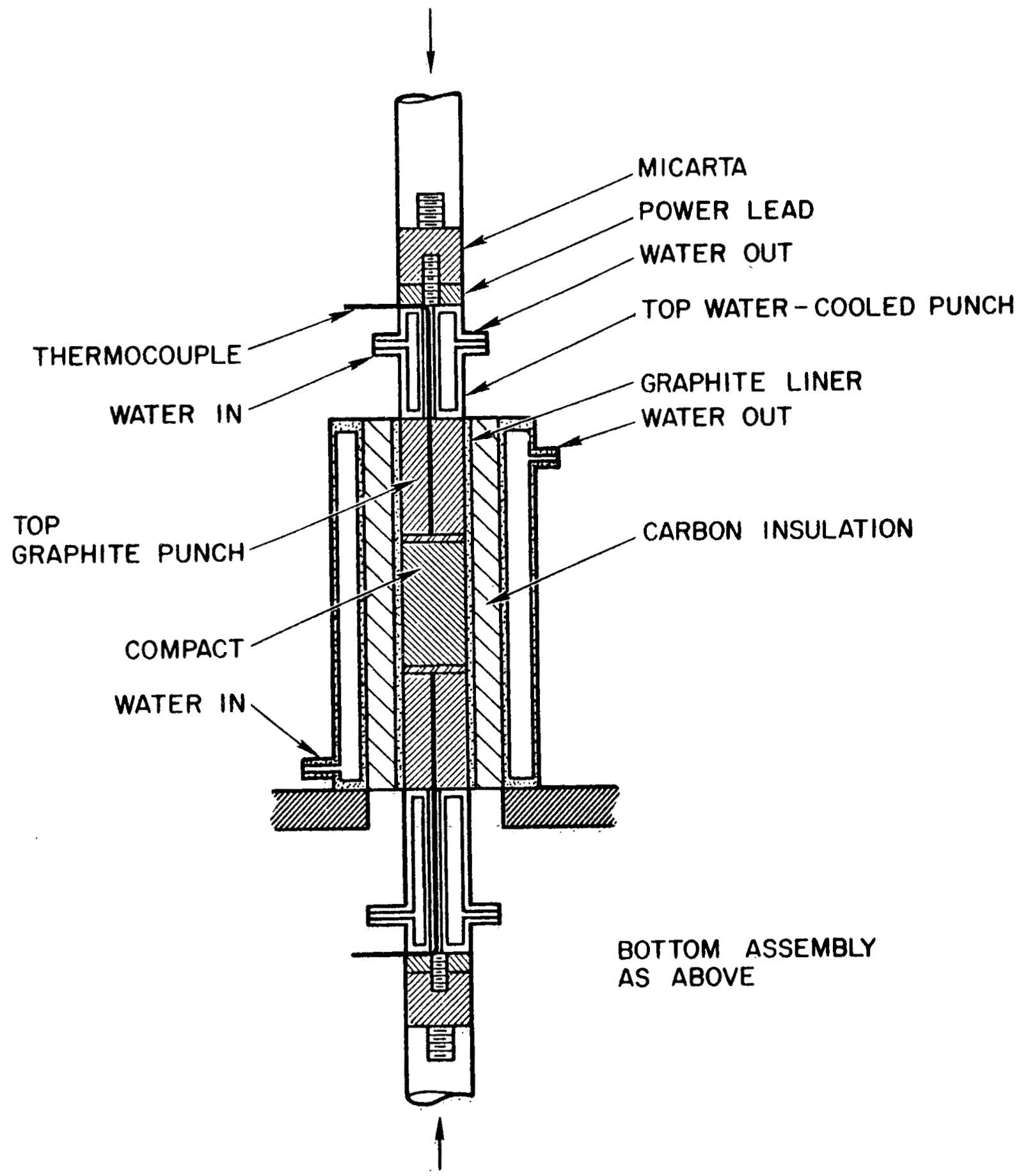

Fig. 7--Warm press used in making solid fuel compacts 


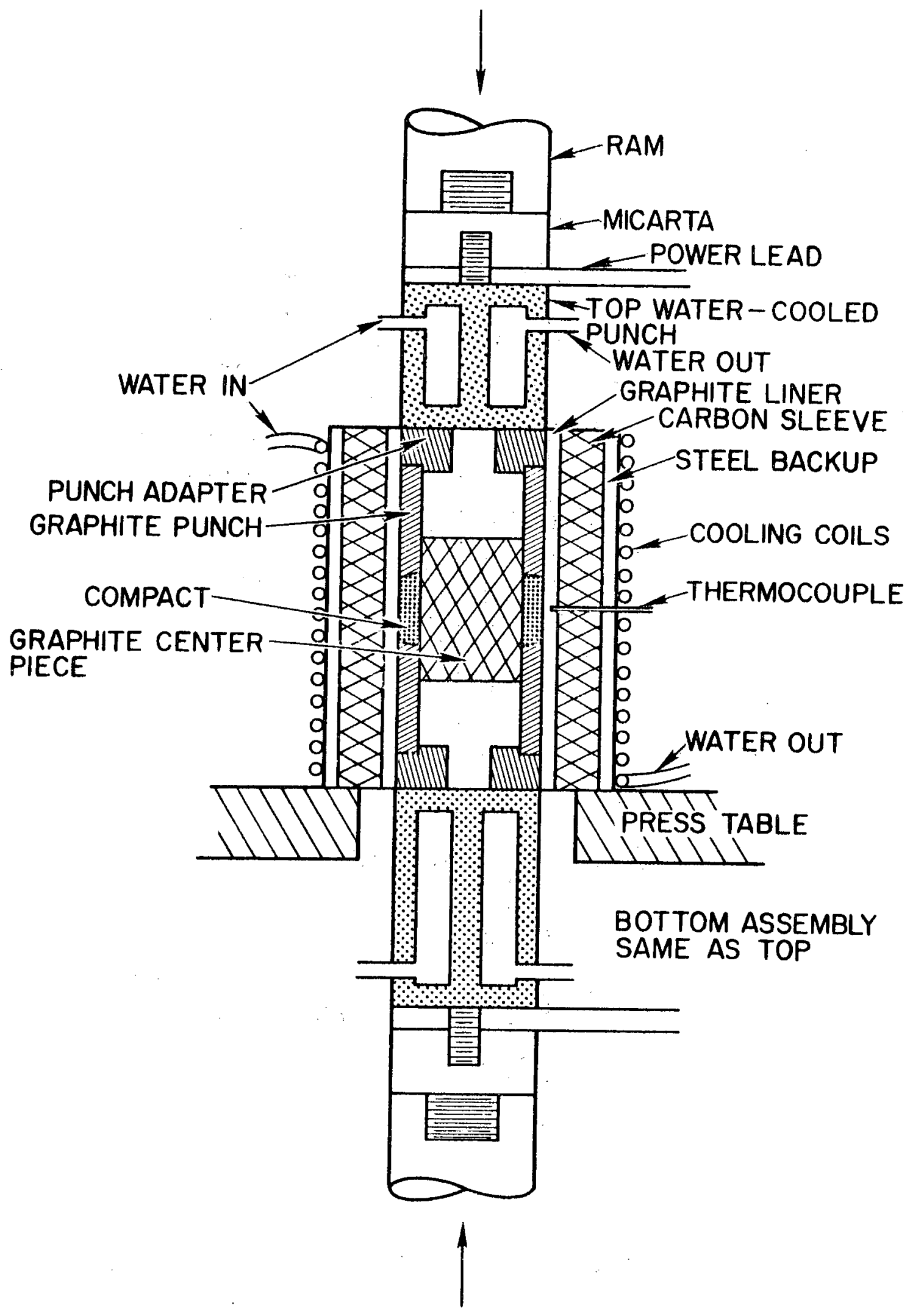

Fig. 8--Warm press used in making annular fuel compacts 


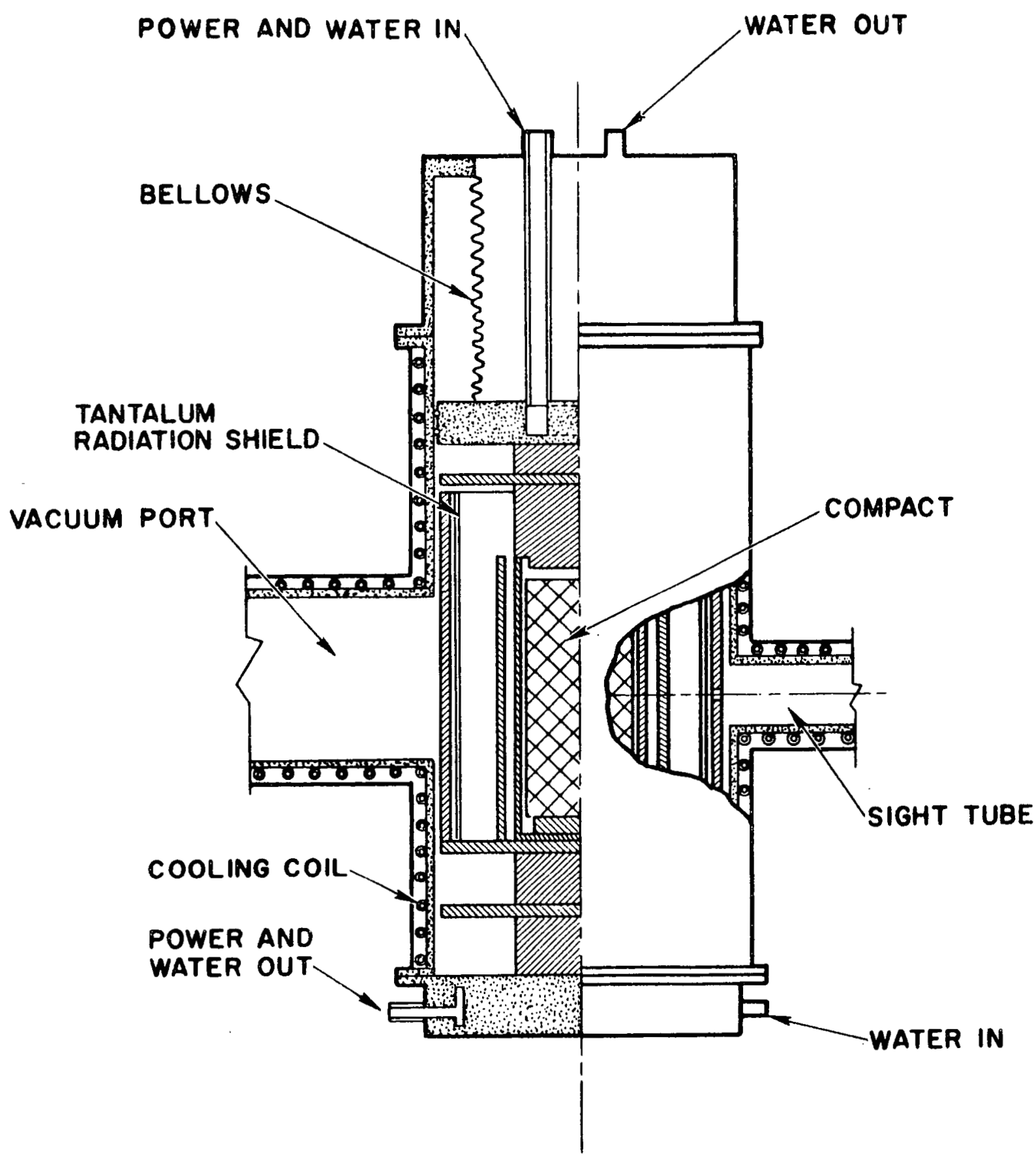

Fig. 9--High-temperature sintering furnace; shaded area is copper or brass, cross-hatched area is graphite 
Mixing and Fuel Distribution

In the initial work on fuel compacts, graphite flour, powdered pitch, and fuel particles were mixed together dry in a twin-shell blender. Because of the large differences in particle size and density, segregation of the fuel was a problem. Quite a bit of care was necessary while unloading the blender and loading the dies to prevent jarring that might cause the heavy fuel particles to settle to the bottom of the mix.

To overcome the segregation problem, the mixture was granulated. A plasticizer was added to the mix to aid in the granulation; it also served as a lubricant to the mix during granulation and added strength to the mix after drying.

Uniformity of fuel distribution in the compacts was determined both qualitatively and quantitatively. Qualitative determination was made by radiographing whole fuel compacts and 1/8-in.- and 1/16-in. -thick slices from compacts. The different fuel-particle sizes can clearly be distinguished in Fig. 10. Quantitative determination of fuel distribution was made by chemical analysis of core samples cut from fuel compacts. The pieces were ignited to a constant weight of $\mathrm{ThO}_{2}-\mathrm{U}_{3} \mathrm{O}_{8}$ and the analyses were reported in weight percent. Data on the chemical analyses of a typical compact cut into 24 equal pieces are given in Table 4 . By selection of location and orientation, it was possible to obtain both longitudinal and transverse composition profiles.

Process Variables

The effects of a number of variables on the properties of the graphite matrix were evaluated by preparing unfueled compacts and measuring the density and the crushing strength. The results are summarized as follows:

Mesh Size of Graphite Flour. Different ranges of mesh size of ground AGOT graphite flour were tested and material of minus -200 to minus -325 was found to produce the best compacts (see Fig. 11). Particles larger than minus-200 mesh produced weaker, less dense compacts, but with powder finer than minus -325 mesh, only a slight decrease in properties occurred. 


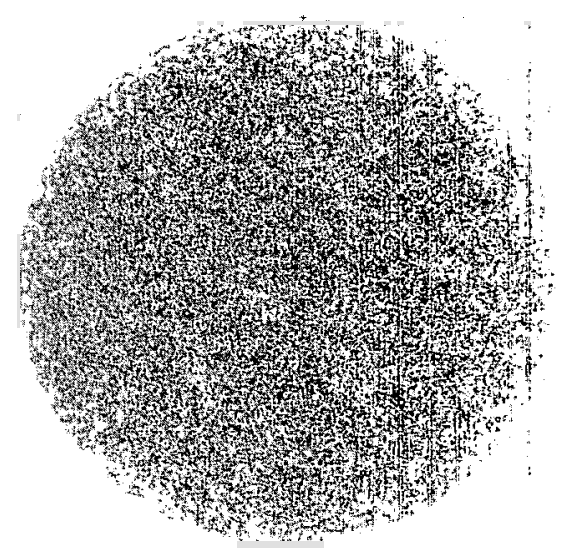

$<50 \mu$ fuel particles
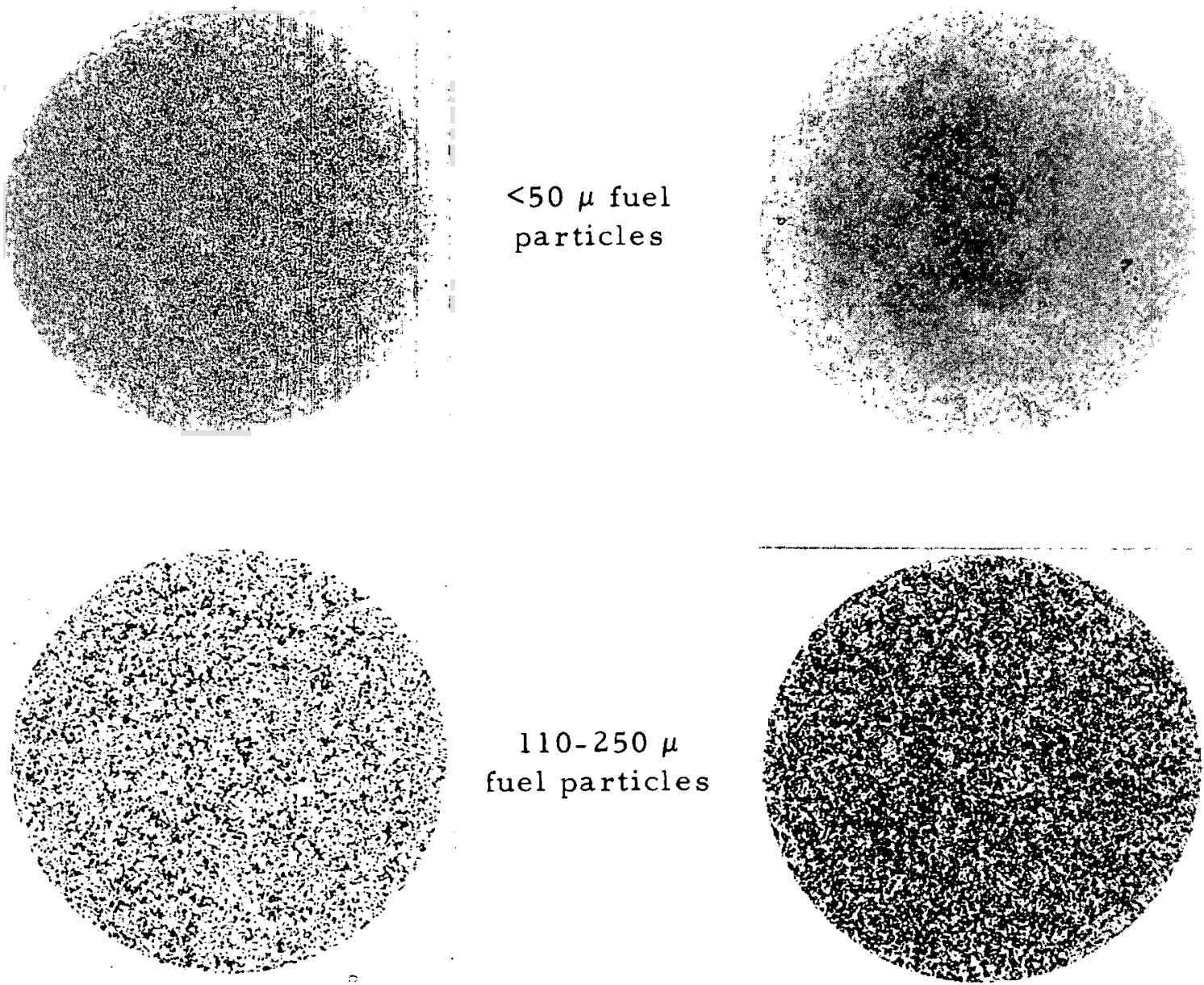

$110-250 \mu$

fuel particles
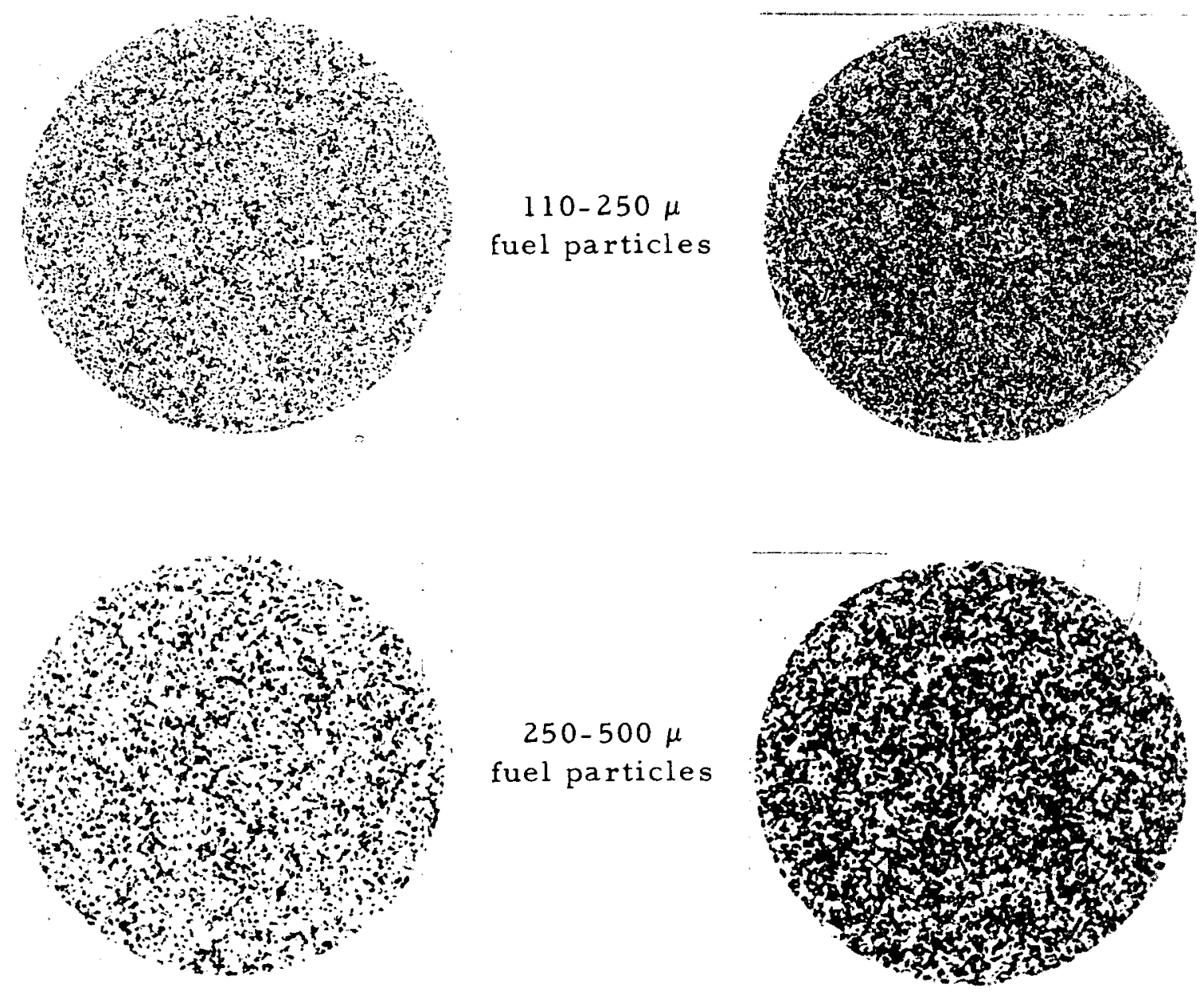

1/16-in. -thick slices

$1 / 8$-in. -thick slices

Fig. 10--Radiographs of slices from fuel compacts showing uniform. fuel distribution 


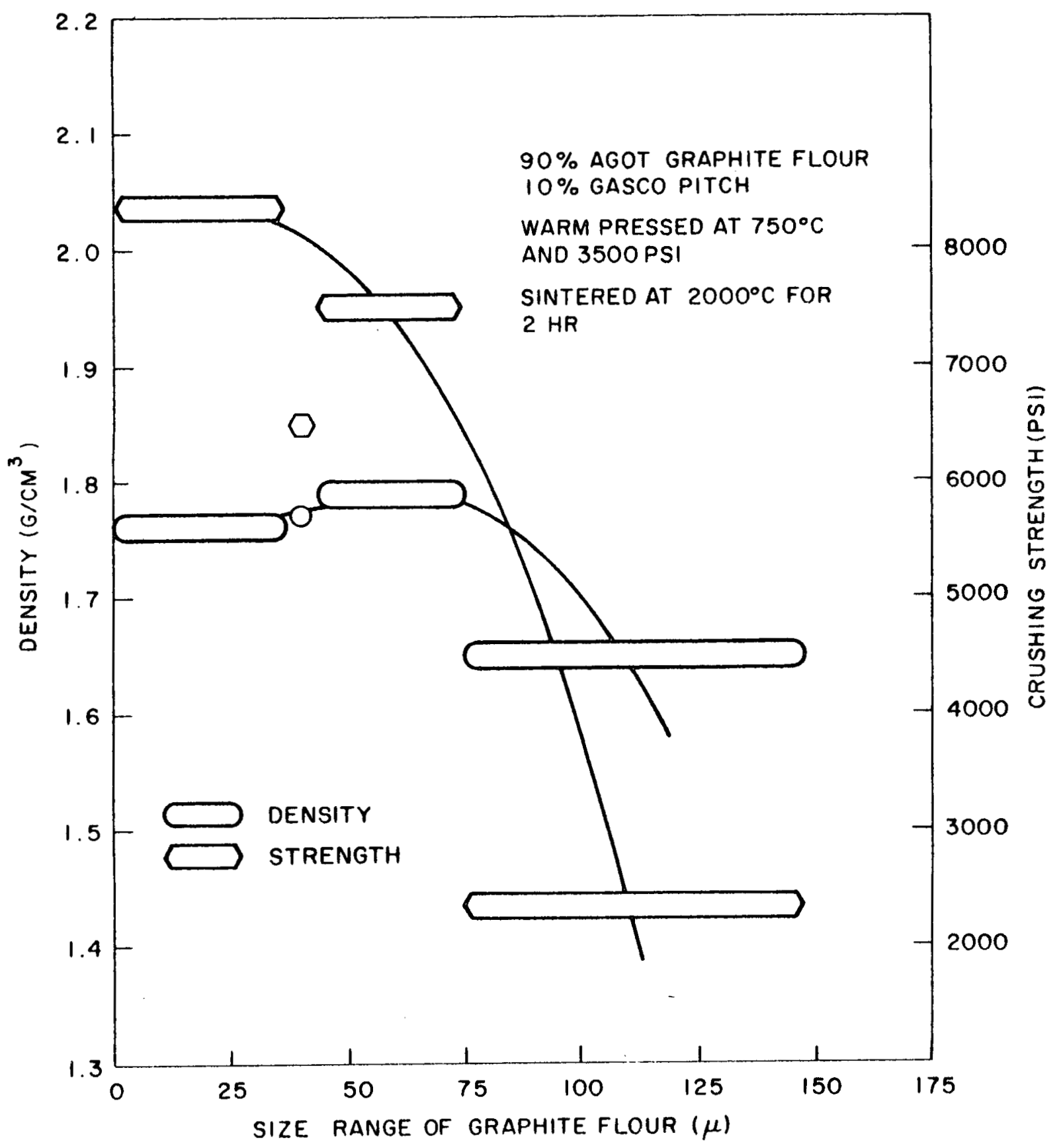

Fig. 11--Variation of compact density and crushing strength with size of graphite flour 
Table 4

RESULT OF IGNITION ANALYSIS FOR FUEL DISTRIBUTION

\begin{tabular}{c|c||c|c}
\hline $\begin{array}{c}\text { No. of } \\
\text { Piece }\end{array}$ & $\begin{array}{c}\mathrm{ThO}_{2}-\mathrm{U}_{3} \mathrm{O}_{8} \\
(w t-\%)\end{array}$ & $\begin{array}{c}\text { No. of } \\
\text { Piece }\end{array}$ & $\begin{array}{c}\mathrm{ThO}_{2}-\mathrm{U}_{3} \mathrm{O}_{8} \\
(w \mathrm{t}-\%)\end{array}$ \\
\hline 1 & 33.0 & 13 & 33.1 \\
2 & 32.9 & 14 & 32.8 \\
3 & 32.9 & 15 & 33.0 \\
4 & 33.1 & 16 & 32.6 \\
5 & 32.9 & 17 & 32.0 \\
6 & 32.5 & 18 & 32.6 \\
7 & 32.7 & 19 & 32.8 \\
8 & 32.8 & 20 & 32.7 \\
9 & 33.0 & 21 & 32.6 \\
10 & 32.8 & 22 & 32.8 \\
11 & 32.5 & 23 & 32.9 \\
12 & 32.7 & 24 & 32.8 \\
\hline
\end{tabular}

NOTE: Theoretical value was $32.3 \mathrm{wt}-\%$; average value was $32.8 \mathrm{wt}-\%$.

Pitch Content. Strength and density of warm-pressed and sintered compacts increased rapidly with increasing pitch content to $10 \%$ by weight, and decreased after 15\% (see Figs. 12 and 13).

Warm-pressing Variables

Graphite-pitch mixtures were pressed over the temperature range from room temperature to over $2200^{\circ} \mathrm{C}$. Good strengths and densities were obtained above $600^{\circ} \mathrm{C}$; the process was relatively insensitive to temperature above this minimum (see Figs. 14 and 15).

No significant effects on compact properties were observed as warmpressing time at $750^{\circ} \mathrm{C}$ was varied up to $1 \mathrm{hr}$.

Compact properties are more dependent on pressure of warm-pressing than on temperature, as can be seen from Figs. 16 and 17. Cold-pressing at high pressures prior to warm-pressing also improves strength and density. 


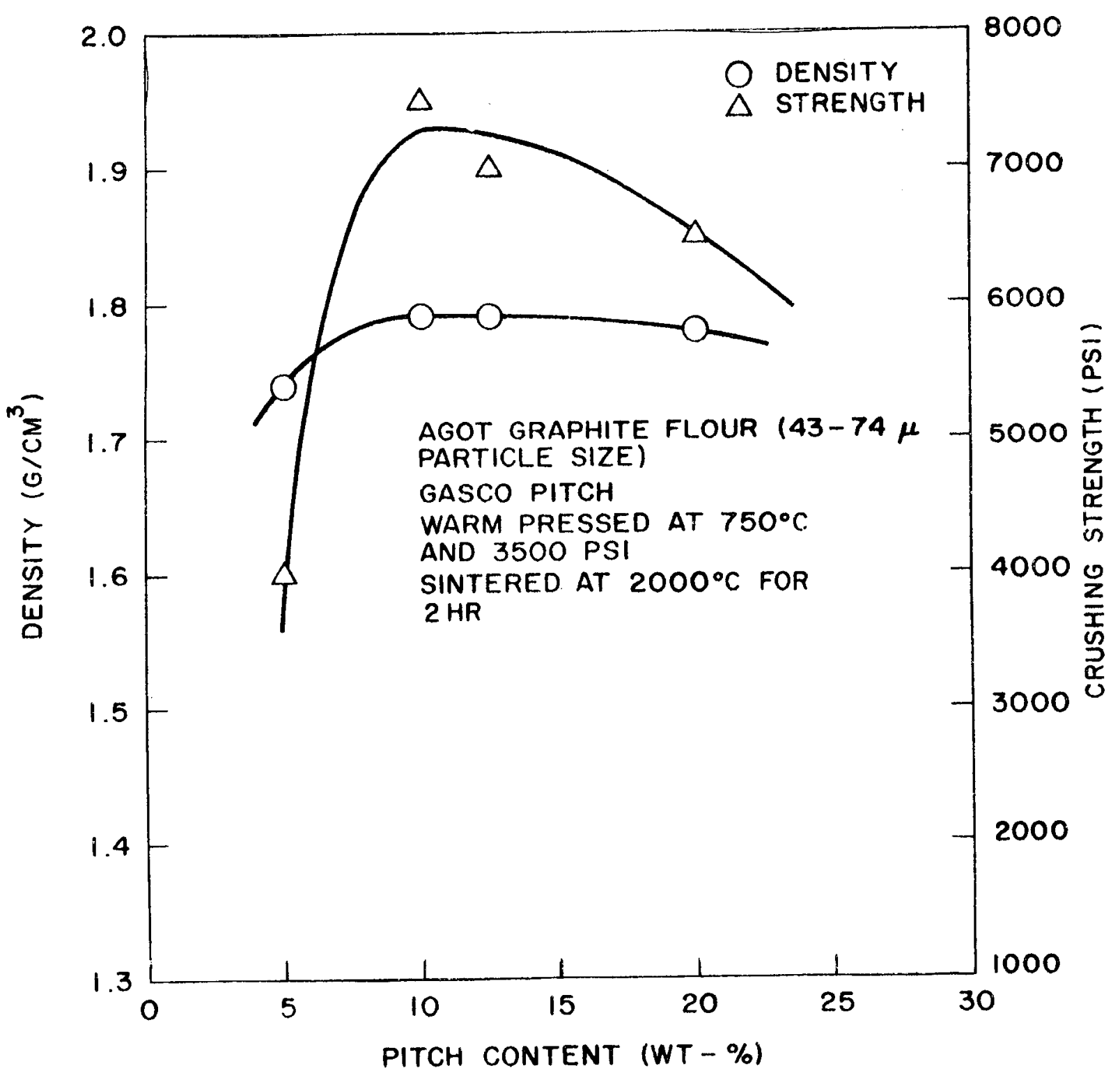

Fig. 12--Variation of density and crushing strength of compacts prepared from AGOT graphite flour with pitch content 


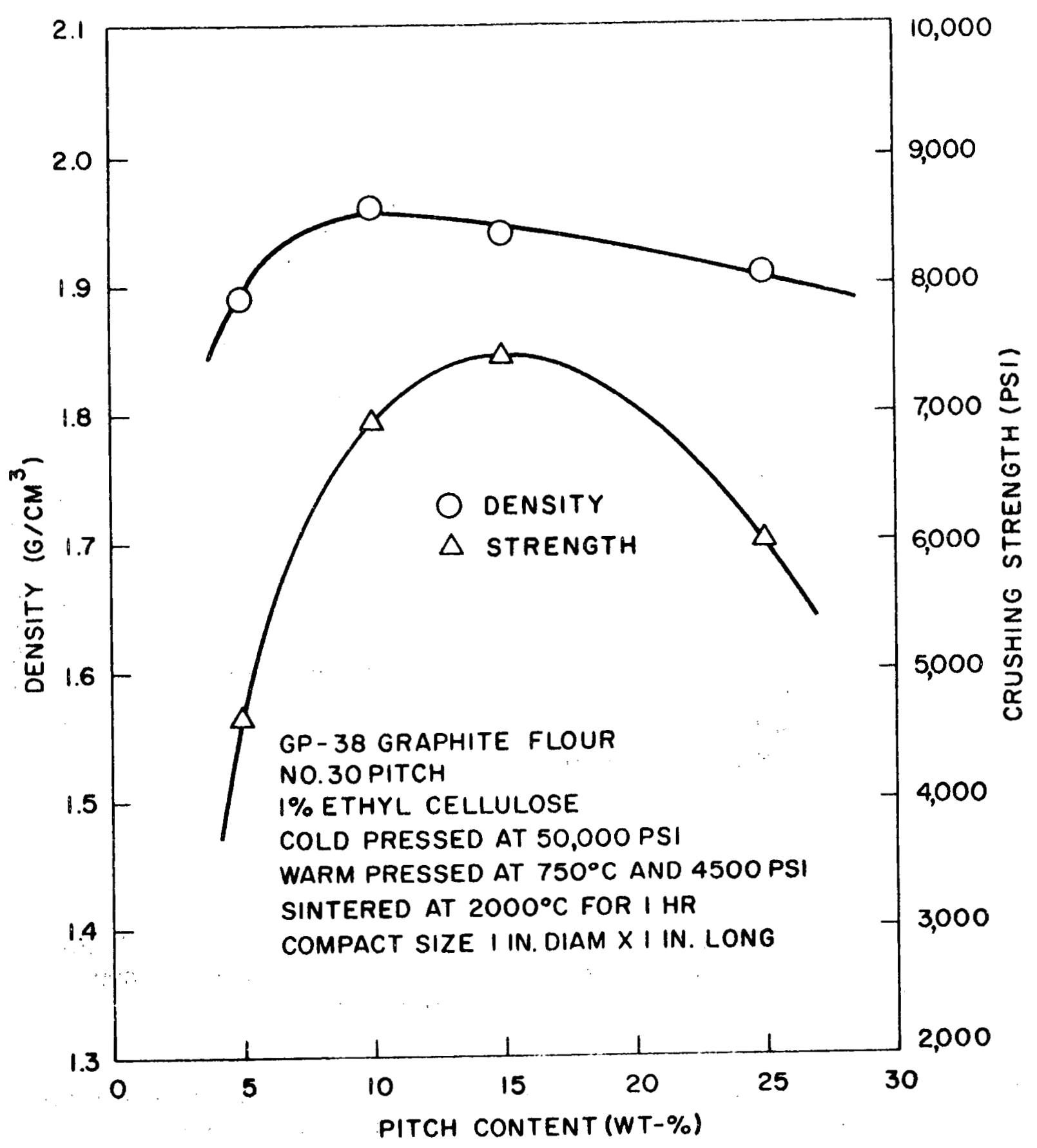

Fig. 13--Variation of density and crushing strength of compacts prepared from GP-38 graphite flour with pitch content 


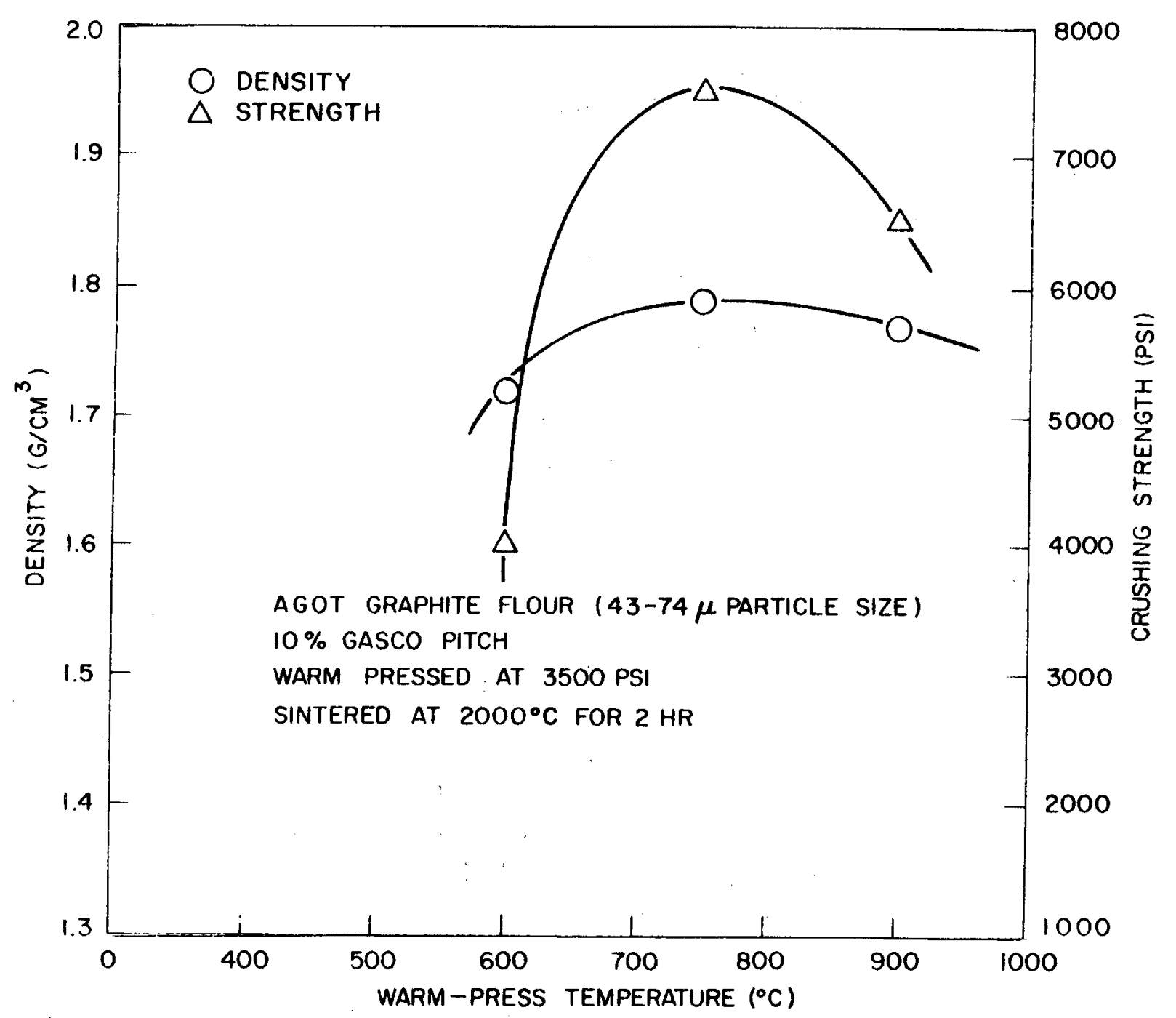

Fig. 14--Variation of density and crushing strength of compacts prepared from AGOT graphite flour with warm-pressing temperature 


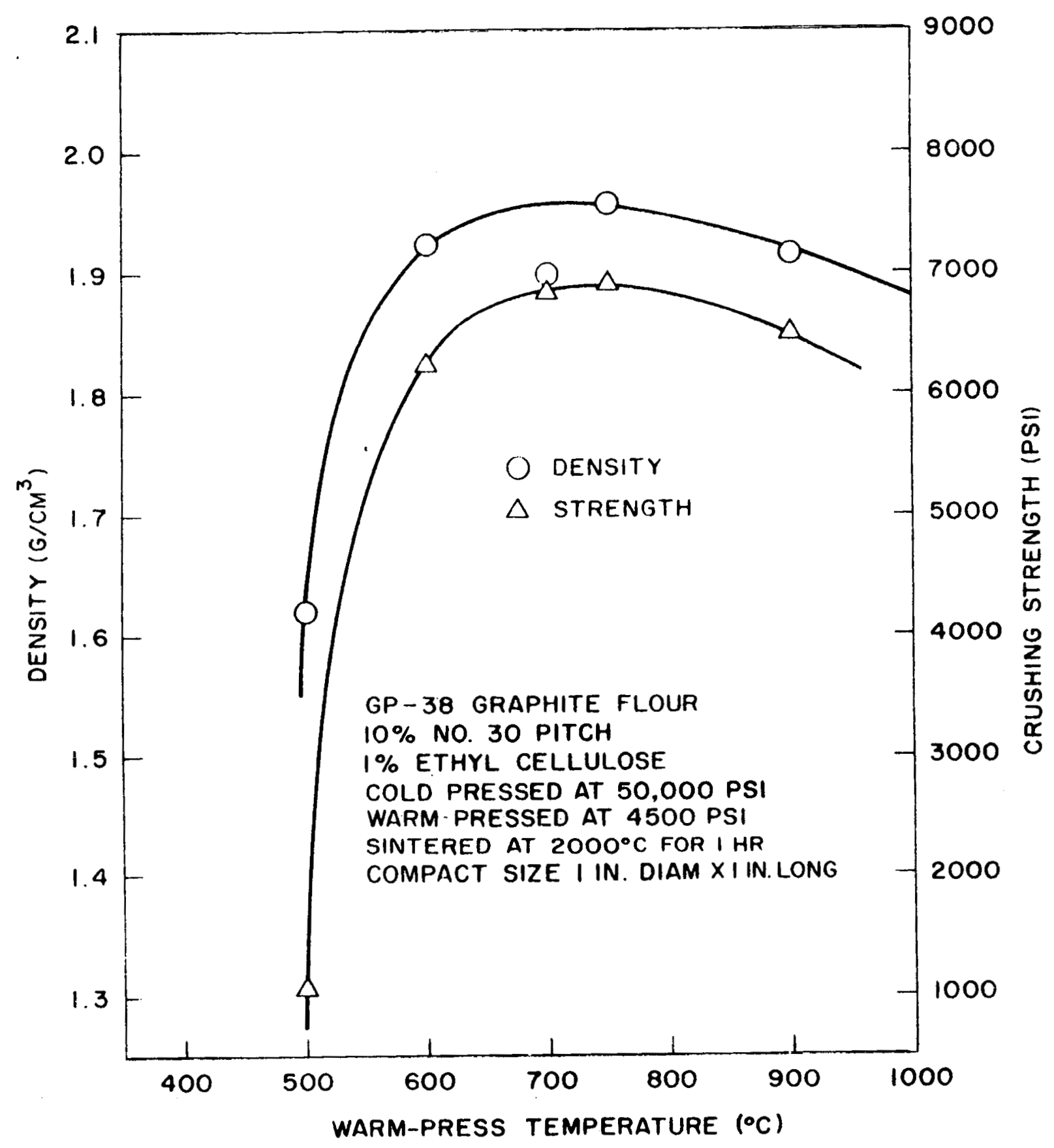

Fig. 15--Variation of density and crushing strength of compacts prepared from GP-38 graphite flour with warm-pressing temperature 


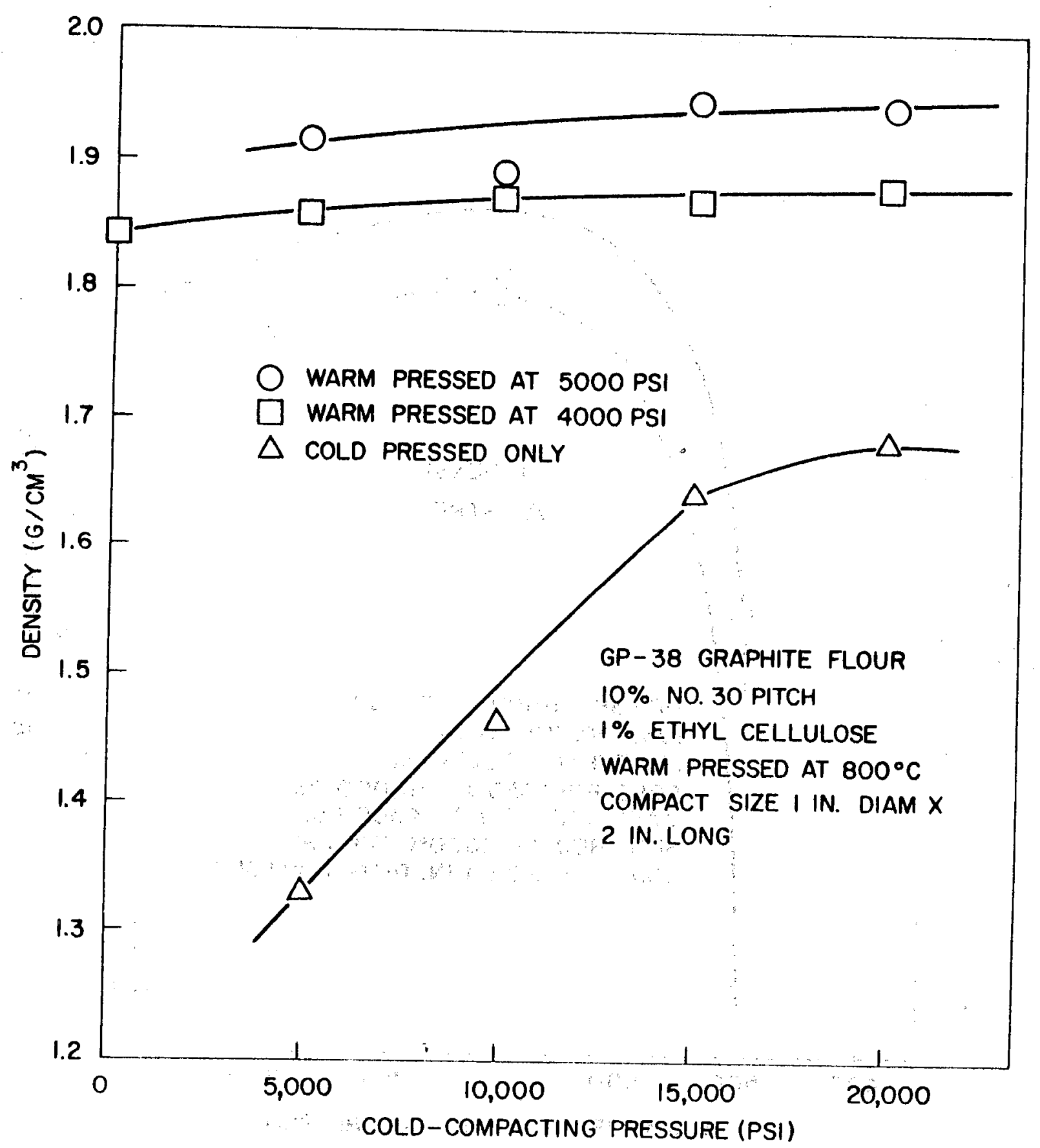

Fig. 16--Variation of compact density with cold- and warm-compacting pressures 


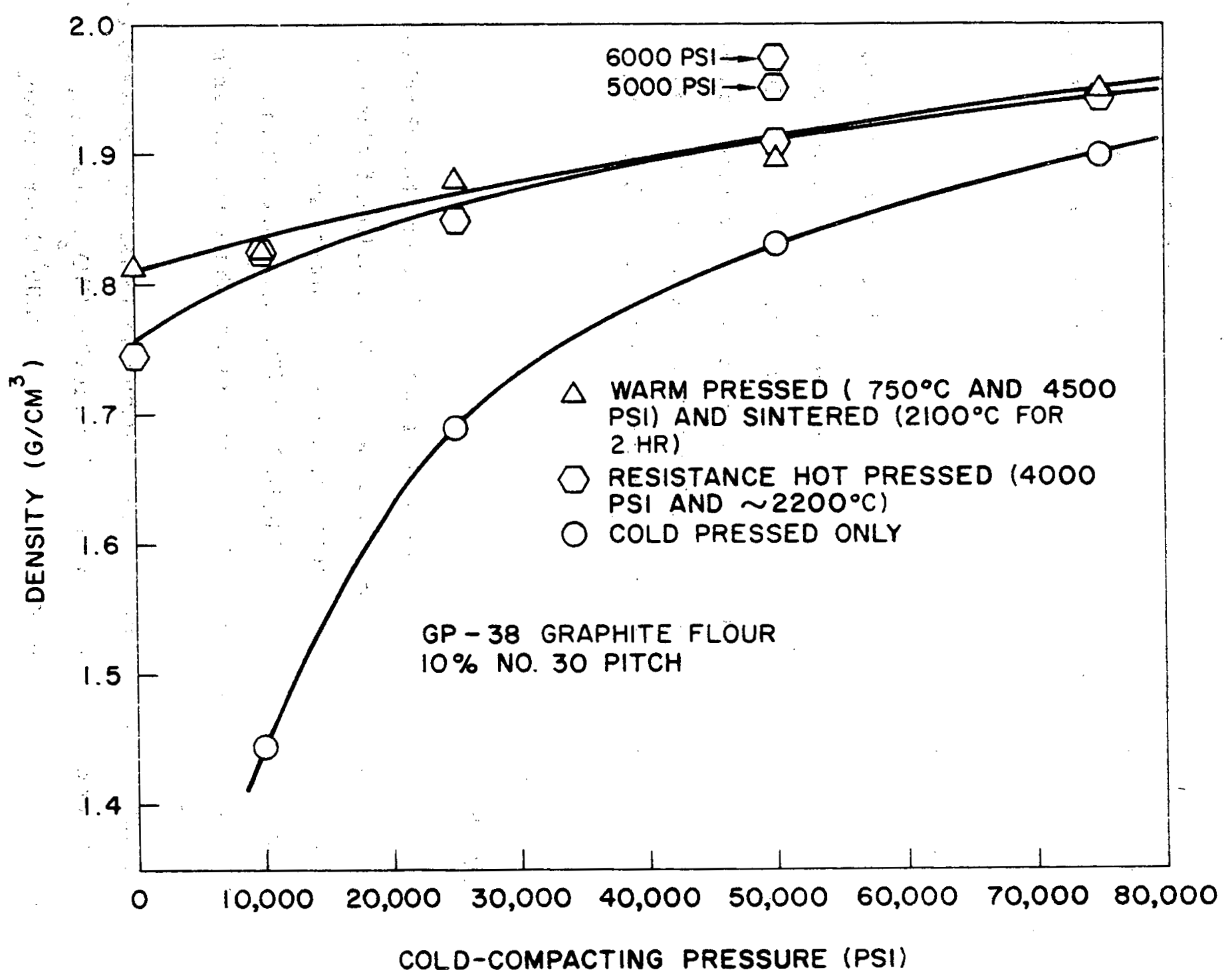

Fig. 17--Density of compacts versus cold-compacting pressure and method of hot-pressing 


\section{Additives}

Use of ethyl cellulose as a plasticizer in mixing and granulating has no deleterious effects on compact properties (see Fig. 18).

Thermax (a high-fired, finely divided carbon black) was added to AGOT-pitch mixtures to improve density and decrease permeability. However, as shown in Fig. 19, density and strength decreased with increasing Thermax additions.

\section{SUMMARY OF HOT-PRESSING TECHNIQUES}

Holding the compacts under pressure while the pitch binder carbonized (warm-pressing) produced high densities and strengths; this was accomplished at temperatures of $600^{\circ} \mathrm{C}$ and above. Increasing the pressure in this temperature range gave increased density and strength, butincreasing the temperature or the time while holding the pressure constant gave no improvement in properties. The optimum pitch content was $10 \%$ to $15 \%$.

\section{FUEL-MATERIAL STUDIES}

Thorium-Uranium Dioxide Fuel

During much of the fuel-development program, solid-solution thoriumuranium dioxide, ( $\mathrm{Th}, \mathrm{U}) \mathrm{O}_{2}$, particles were used as the starting fuel material. It was therefore necessary to know (1) the temperature and time required for the in situ conversion of $(\mathrm{Th}, \mathrm{U}) \mathrm{O}_{2}$ to $(\mathrm{Th}, \mathrm{U}) \mathrm{C}_{2}$ and (2) the size and integrity of the converted carbide particles and their relationship to the graphite matrix.

In order to determine the minimum conditions necessary for conversion of the oxides to carbides, compacts prepared from $(\mathrm{Th}, \mathrm{U}) \mathrm{O}_{2}$, graphite, and pitch were sintered at temperatures from $1200^{\circ}$ to $2200^{\circ} \mathrm{C}$ for varying times, and were then examined by X-ray diffraction. Strong oxide lines were present in the films of samples sintered between $1200^{\circ}$ and $1800^{\circ} \mathrm{C}$, and they were still present after $4 \mathrm{hr}$ at $1800^{\circ} \mathrm{C}$. Very weak monocarbide 


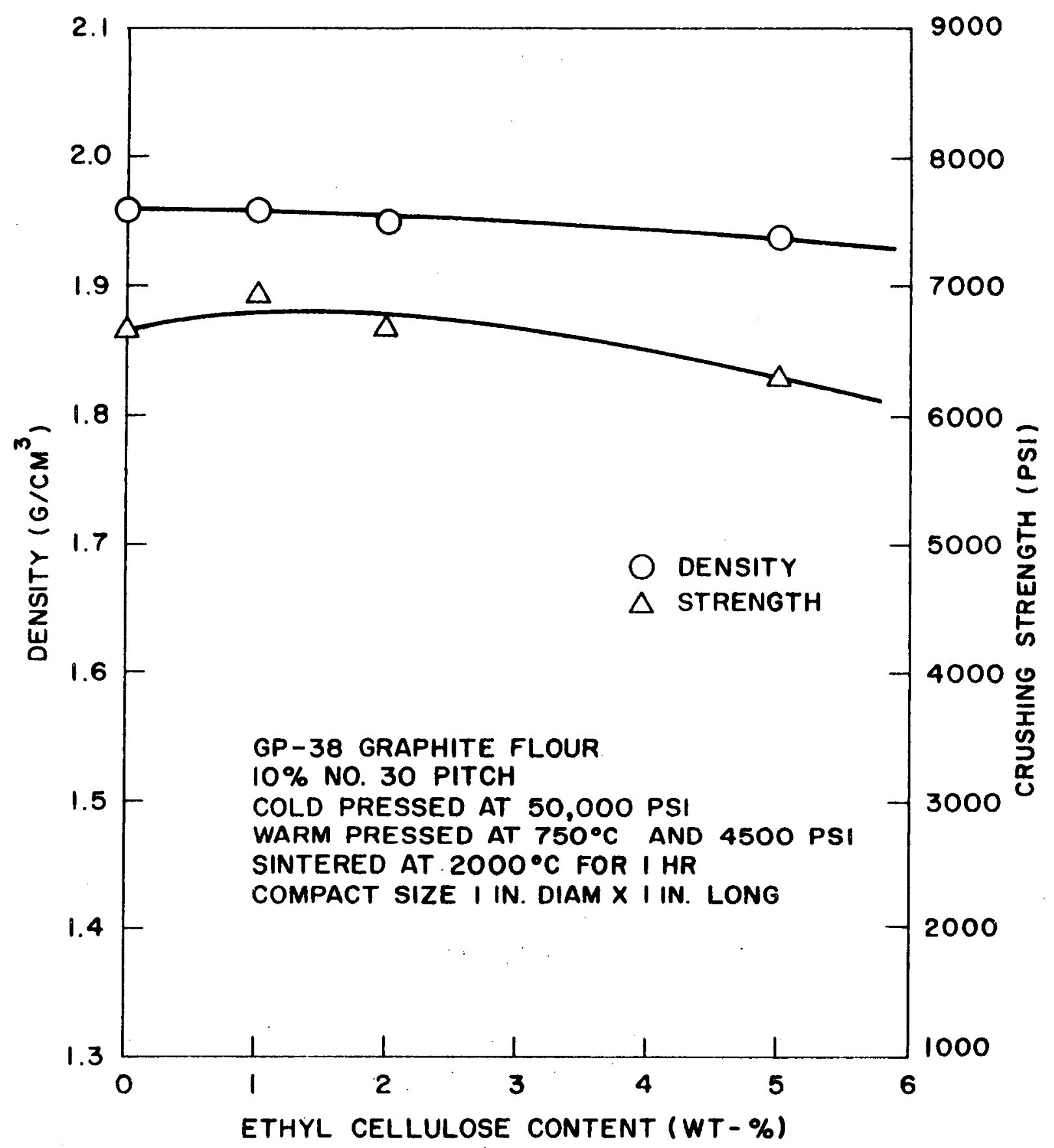

Fig. 18--Variation of compact density and crushing strength with ethyl cellulose content 


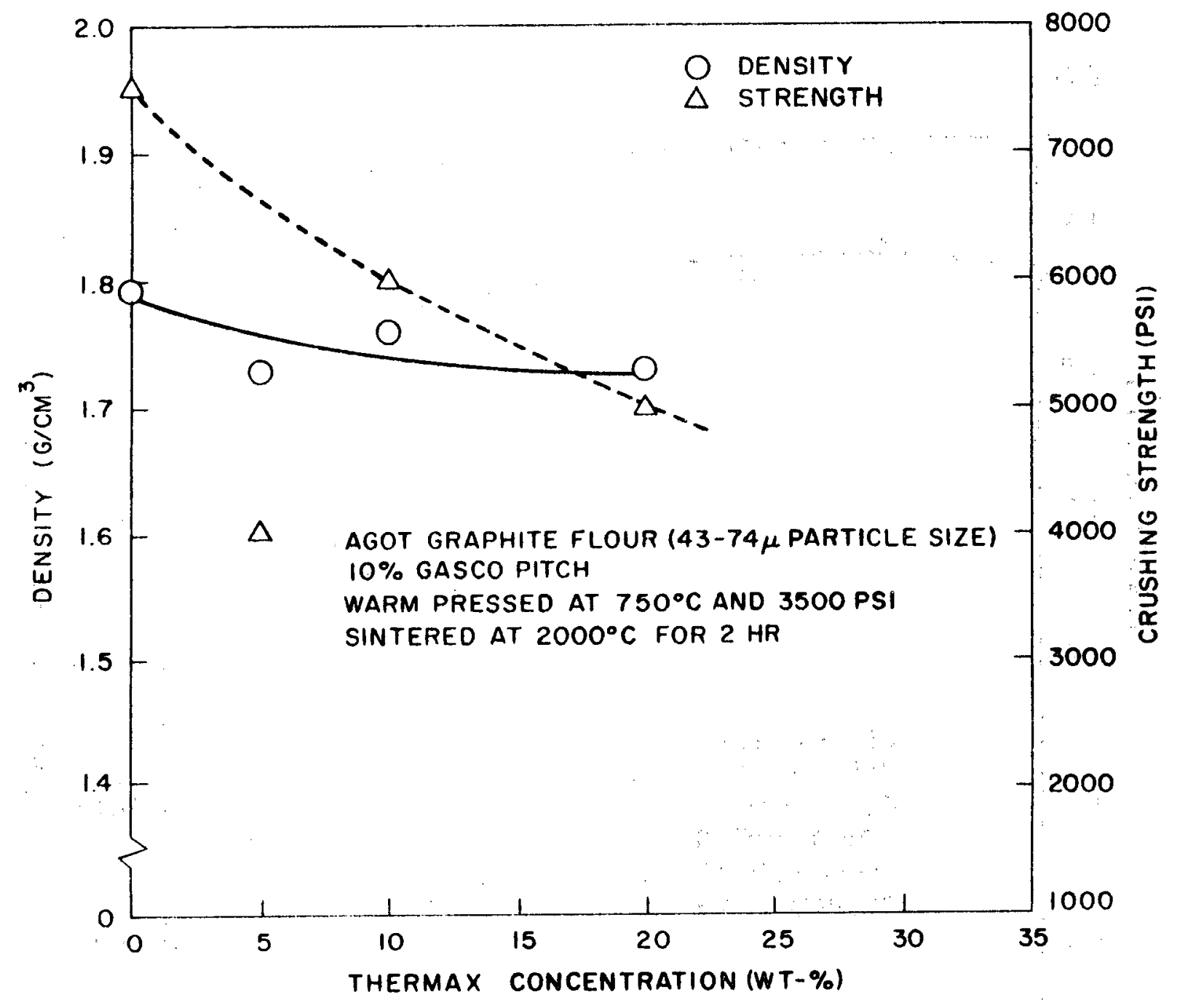

Fig. 19--Variation of compact density and crushing strength with Thermax concentration 
lines were first detected at a sintering temperature of $1600^{\circ} \mathrm{C}$, and mixed monocarbides and dicarbides were identified after heating at $2000^{\circ} \mathrm{C}$. The minimum condition for complete conversion of $(\mathrm{Th}, \mathrm{U}) \mathrm{O}_{2}$ to $(\mathrm{Th}, \mathrm{U}) \mathrm{C}_{2}$ was found to be $2 \mathrm{hr}$ at $2100^{\circ} \mathrm{C}$.

The sensitivity of $\mathrm{X}$-ray diffraction for identifying oxides in the presence of carbides was determined. ( $(\mathrm{Th}, \mathrm{U}) \mathrm{O}_{2}$ and $(\mathrm{Th}, \mathrm{U}) \mathrm{C}_{2}$ powders were physically mixed, and X-ray films of the powder were obtained. A photodensitometer trace was made on the films by scanning several distinct oxide and carbide lines; thus providing a relative measure of their intensities. The results are given in Table 5 .

Table 5

X-RAY DIFFRACTION ANALYSIS OF MIXTURES

$\mathrm{OF}(\mathrm{Th}, \mathrm{U}) \mathrm{O}_{2}-(\mathrm{Th}, \mathrm{U}) \mathrm{C}_{2}$

\begin{tabular}{|c|c|c|c|}
\hline \multicolumn{2}{|c|}{$\begin{array}{c}\text { Composition } \\
(w t-\%)\end{array}$} & \multirow{2}{*}{$\begin{array}{l}\text { Relative Line Intensities } \\
\frac{I_{\text {carbide, } 25.1^{\circ}(20)}}{I_{\text {oxide }, 32.4^{\circ}(20)}}\end{array}$} & \multirow{2}{*}{ Remarks } \\
\hline$(\mathrm{Th}, \mathrm{U}) \mathrm{C}_{2}$ & $(\mathrm{Th}, \mathrm{U}) \mathrm{O}_{2}$ & & \\
\hline 50 & 50 & 1.33 & Strong oxide lines \\
\hline 75 & 25 & 1.65 & Weak oxide lines \\
\hline 90 & 10 & 3.20 & $\begin{array}{l}\text { Oxide lines barely } \\
\text { visible }\end{array}$ \\
\hline
\end{tabular}

It appears that X-ray films of powder cannot be used to detect $(\mathrm{Th}, \mathrm{U}) \mathrm{O}_{2}$ in the presence of $(\mathrm{Th}, \mathrm{U}) \mathrm{C}_{2}$ in the range 0 to $10 \cdot \mathrm{wt}-\%$. The addition of the graphite matrix would further dilute the oxide; thus X-ray diffraction does not appear to be a good quantitative tool for measuring the conversion of oxides to carbides.

As another possible means of studying the in situ conversion of $(\mathrm{Th}, \mathrm{U}) \mathrm{O}_{2}$ to $(\mathrm{Th}, \mathrm{U}) \mathrm{C}_{2}$, electrical resistivity was measured as a function of sintering temperature on a compact containing ( $\mathrm{Th}, \mathrm{U}) \mathrm{O}_{2}$ and on similar. unfueled compacts. The results indicated that the oxide particles did not 
influence the electrical resistivity of the compact. However, the electrical conductivity of the fueled compact started to improve significantly between $1800^{\circ}$ and $2000^{\circ} \mathrm{C}$, whereas that of the unfueled compact improved only slightly. After a $2000^{\circ} \mathrm{C}$ heat treatment, $(\mathrm{Th}, \mathrm{U}) \mathrm{C}_{2}$ lines appeared on the $\mathrm{X}$-ray diffraction patter $\mathrm{n}$, indicating that the lowering of resistivity coincided with the conversion of the oxides to dicarbides.

Metallographic examination of sintered fuel compacts revealed that the $(\mathrm{Th}, \mathrm{U}) \mathrm{C}_{2}$ particles retained the size and shape of the parent $(\mathrm{Th}, \mathrm{U}) \mathrm{O}_{2}$ particles (see Figs. 20 and 21). A considerable portion of the graphite surrounding each particle was consumed by the conversion reaction

$$
(\mathrm{Th}, \mathrm{U}) \mathrm{O}_{2}+4 \mathrm{C} \rightarrow(\mathrm{Th}, \mathrm{U}) \mathrm{C}_{2}+2 \mathrm{CO}
$$

which left a void between the particles and the matrix, as can be seen in Fig. 21. No cracking or segregation of the particles was observed. However, the reverse reaction (hydrolysis) was found to cause disintegration of the carbide particles, which resulted in finely divided, amorphous oxide powders.

The variation of fuel-compact density with fuel loading for compacts prepared from oxides is shown in Fig. 22. Compacts containing over $40 \mathrm{wt}-\%$ metal $(\mathrm{Th}+\mathrm{U})$ were produced from $(\mathrm{Th}, \mathrm{U}) \mathrm{O}_{2}$ by the warm-press and sinter technique. However, the strength of the se compacts was found to decrease rapidly at loadings greater than $40 \mathrm{wt}-\%$ owing to the large graphite-matrix losses in the conversion reaction.

In preparing full-sized compacts by this process, it was necessary to pre-form the smaller units by cold-pressing and then to assemble the seven component pieces as shown in Fig. 23 before warm-pressing the assembly into an integral compact. The multicomponent arrangement was necessary to avoid dimensional distortion during fabrication.

Thorium-Uranium Silicide Fuel

Both oxides and carbides have disadvantages as fuel materials for 


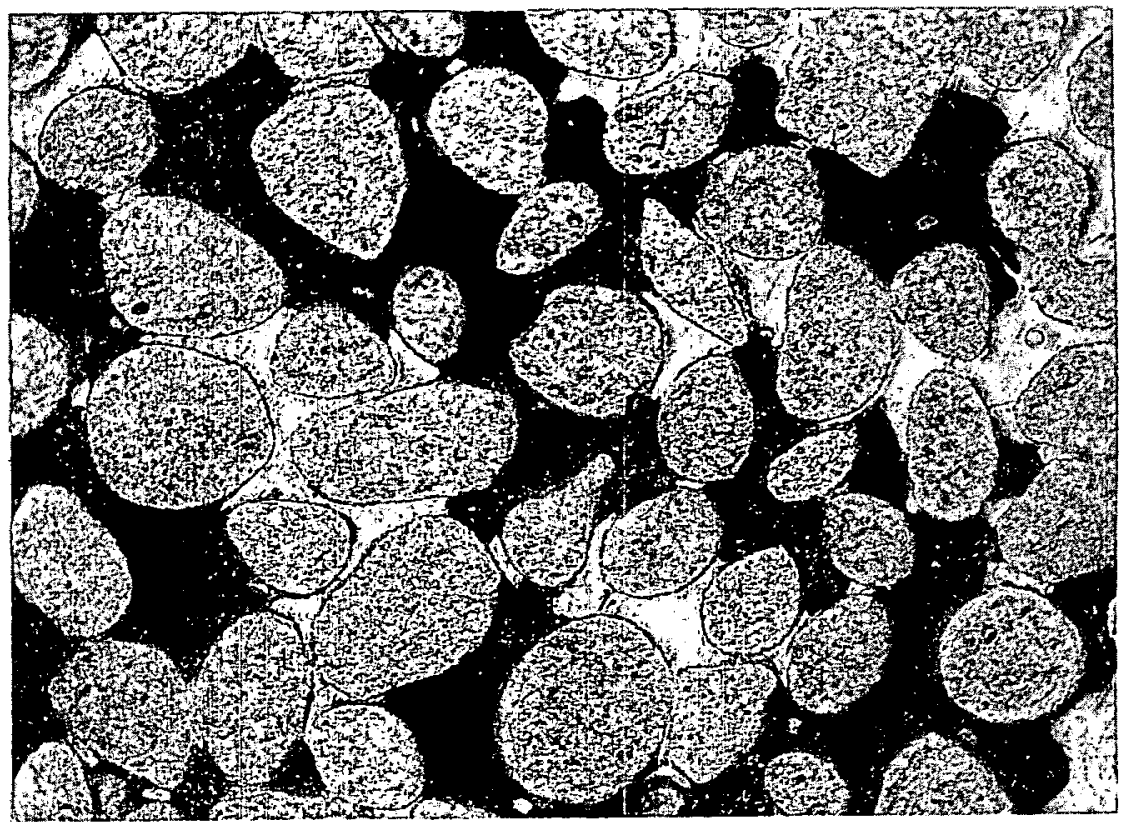

$(75 \times)$

Fig. 20--Photomicrograph of $(\mathrm{Th}, \mathrm{U}) \mathrm{O}_{2}$ fuel particles

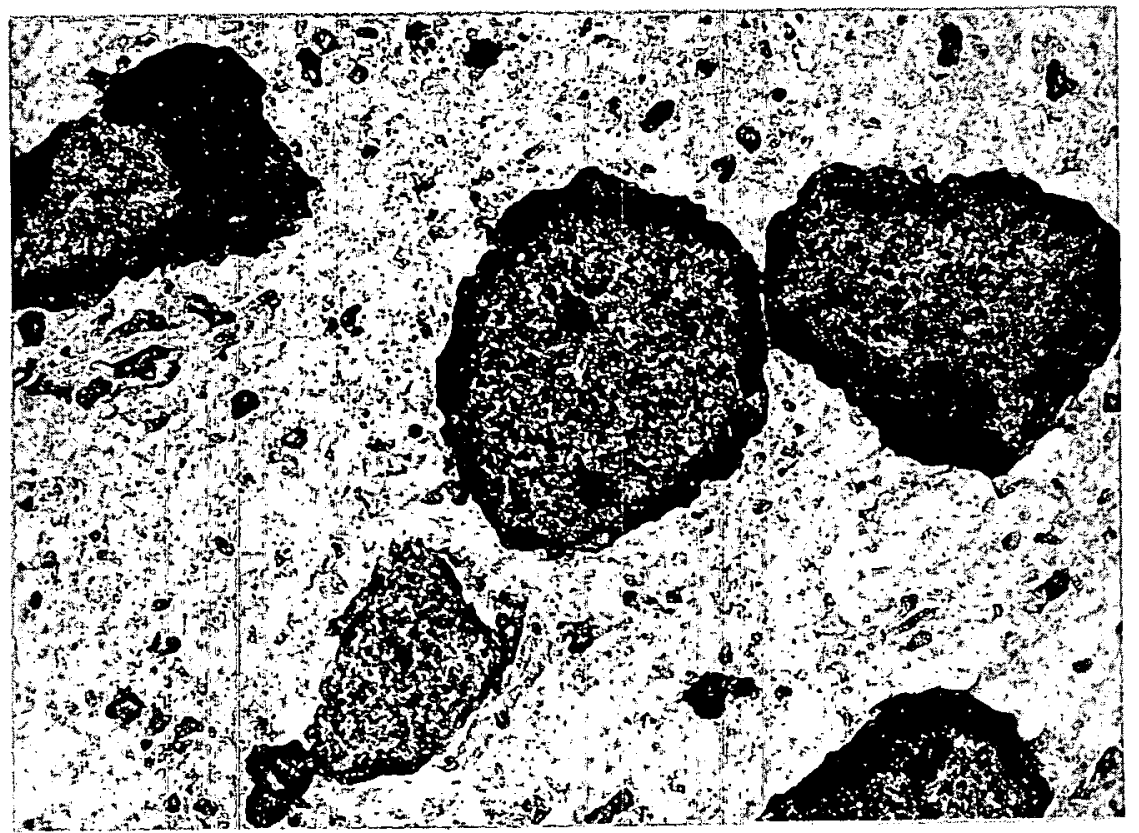

Fig. 21--Photomic rograph of $(\mathrm{Th}, \mathrm{U}) \mathrm{C}_{2}$ fuel particles formed by in situ conversion of $(\mathrm{Th}, \mathrm{U}) \mathrm{O}_{2}$ particles during fuel-compact fabrication; note voids between particles and graphite matrix 


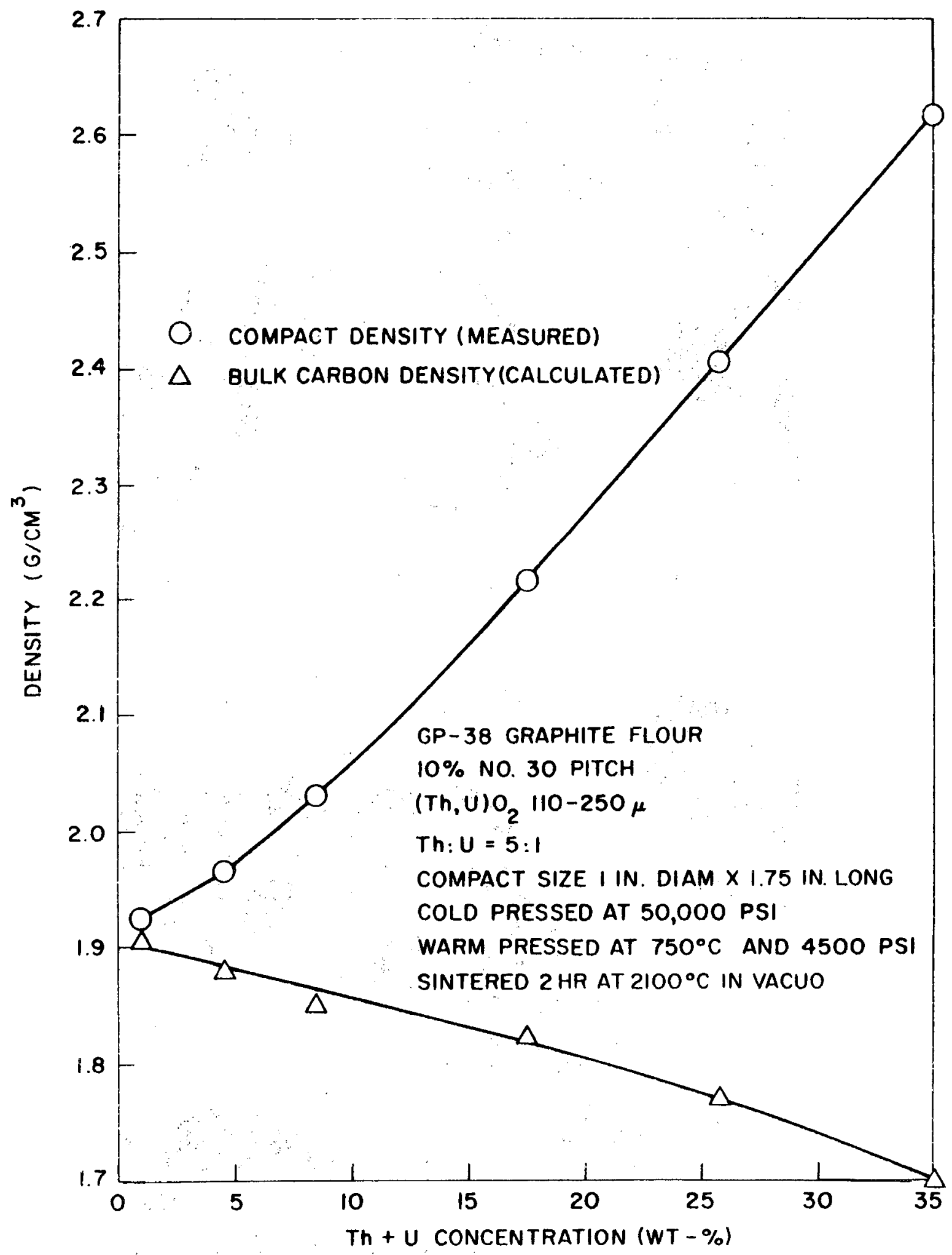

Fig. 22--Variation of fuel-compact density with metal (Th+U) content for compacts prepared from $(\mathrm{Th}, \mathrm{U}) \mathrm{O}_{2}$ 
$\bullet$
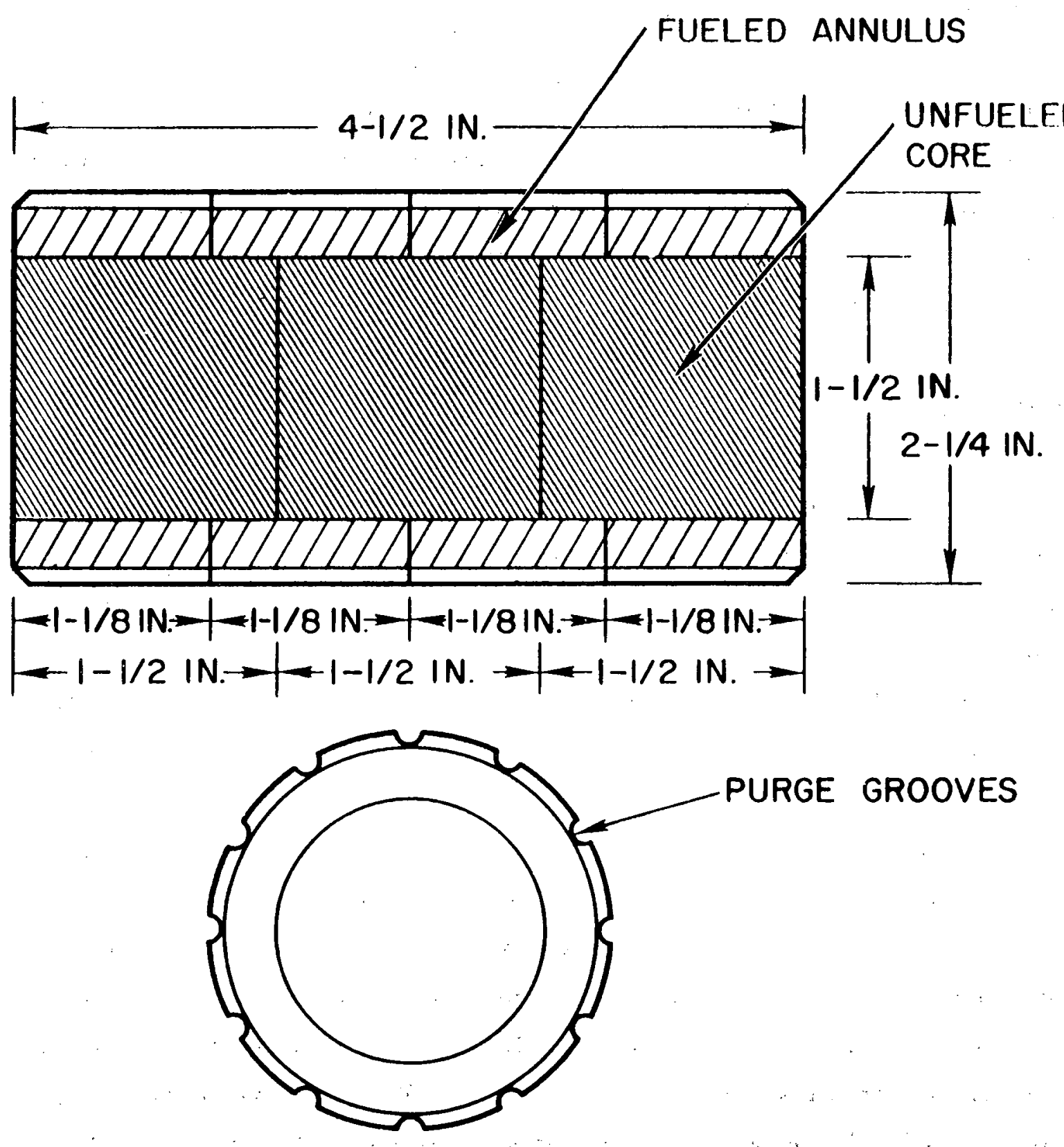

Fig. 23--Drawing of fuel compact preparéd by converted-oxide process 
compact fabrication. On the one hand, in situ conversion of $(\mathrm{Th}, \mathrm{U}) \mathrm{O}_{2}$ to $(\mathrm{Th}, \mathrm{U}) \mathrm{C}_{2}$ liberates two moles of carbon monoxide per mole of carbide and consumes four moles of carbon from the fuel compact matrix immediately adjacent to the fuel particles. This creates considerable porosity in the compacts and makes it difficult to obtain useful fission-gas retention. On the other hand, thorium-uranium carbide prepared by arc-melting is difficult to grind to $150 \mu$ particles because of its hardness. Also, the extreme moisture reactivity of the $\mathrm{ThC}_{2}$ in air makes it difficult to handle during its incorporation in the fuel compacts.

A search was made to find a fuel material that was stable in air, that was readily formed into particles, and that released no gases when converted to carbide in the compact. Thorium and uranium silicides appeared to meet all these criteria: they are fairly stable in air and are quite brittle, and furthermore, during the sintering of the fuel compact and the formation of carbides of thorium, uranium, and silicon no gaseous products should escape that would cause porosity in the compact. In addition, the metalrich silicides of thorium and uranium $\left(\mathrm{U}_{3} \mathrm{Si}, \mathrm{U}_{3} \mathrm{Si}_{2}\right.$, and $\left.\mathrm{Th}_{3} \mathrm{Si}_{2}\right)$ are isomorphous (tetragonal crystal structure) and should form solid solutions.

Uranium silicides containing $7.4 \%$ to $18.5 \%$ silicon and thoriumuranium silicides containing $6.4 \%$ to $20 \%$ silicon and having a thorium-touranium ratio of 5:2 were prepared by arc-melting crystal bar thorium, high-purity uranium, and purified silicon. Each button was turned over and remelted several times to ensure homogeneity. These buttons were ground in a blender, using a tungsten carbide vial and ball to minimize contamination. (Uranium-silicon alloys containing $7.4 \%$ to $18.5 \%$ silicon were easilycrushed, but $\mathrm{U}_{3} \mathrm{Si}(3.8 \%$ silicon) was too malleable to be crushed to a powder.) These silicides, even though finely ground, appeared to be stable in air. Three mesh sizes of each composition were obtained for fuel-compact studies, and $\mathrm{X}$-ray patterns were obtained on minus -300 mesh powder from each specimen. The $\mathrm{X}$-ray diffraction results are summarized in Table 6 . $\mathrm{X}$-ray diffraction was used to study the conversion of thorium-uranium 
Table 6

X-RAY ANALYSES OF THORIUM-URANIUM SILICIDES

$(T h: U=5.2)$

\begin{tabular}{|c|c|}
\hline $\begin{array}{l}\text { Silicon } \\
\text { Content } \\
\quad(\%)\end{array}$ & Results \\
\hline 6.4$\}$ & Patterns appeared identical, revealing \\
\hline 7.4 & $\mathrm{M}_{3} \mathrm{Si}_{2}$-type compound; no oxide \\
\hline 10 & $\begin{array}{l}\text { Mixture of } \mathrm{M}_{3} \mathrm{Si}_{2}-\text { and MSi-type compounds; } \\
\text { no oxide }\end{array}$ \\
\hline 15 & $\begin{array}{l}\mathrm{MSi}_{2} \text {-type compound, plus trace of another } \\
\text { compound for which no comparison avail- } \\
\text { able (probably } \mathrm{M}_{2} \mathrm{Si}_{3} \text { type) }\end{array}$ \\
\hline 20 & $\begin{array}{l}\mathrm{MSi}_{2} \text {-type compound, trace of unidentified } \\
\text { compound (probably } \mathrm{MSi}_{3} \text {-type); no oxide }\end{array}$ \\
\hline
\end{tabular}

NOTE: Visual comparisons were made with diffracted patterns of thorium silicides as recorded by Freeman, et al. (Ref. 5).

silicides to carbides. Fuel particle size, sintering time, and temperature were investigated. The thorium-uranium (5:2 atom ratio) silicides varied in composition from 6.4 to $20 \mathrm{wt}-\% \mathrm{Si}$. These compounds were crushed and sieved into three ranges of particle size $(250$ to $500 \mu, 110$ to $250 \mu$, and $<50 \mu$ ) and were then mixed with graphite and pitch, and compacted. Compacts of each silicon composition and particle size were sintered at $2000^{\circ} \mathrm{C}$ for periods of $\mathrm{l}$ and $2 \mathrm{hr}$. The effects of the different variables were as follows:

1. Sintering for $2 \mathrm{hr}$ at $2000^{\circ} \mathrm{C}$ was necessary for complete conversion of the thorium-uranium silicides to dicarbides for all silicon compositions, with the exception of the samples that contained the large silicide particles $(250$ to $500 \mu)$. This indicates that the reaction process is probably diffusion controlled.

2. Each specimen still retained silicon carbide, which was detectable in the $\mathrm{X}$-ray pattern. This implies that the vapor pressure of silicon over silicon carbide was not sufficient to cause complete 
volatilization of the silicon from the specimens during the vacuumsintering conversion process (see remarks on vapor pressure below).

The minimum conditions required for the complete conversion of silicide to carbide are compared below with the data previously reported for the conversion of oxide to carbide:

$$
\begin{aligned}
& \mathrm{ThO}_{2}-\mathrm{UO}_{2}+\mathrm{C} \rightarrow \mathrm{ThC}_{2}-\mathrm{UC}_{2} \ldots .4 \mathrm{hr} \text { at } 2000^{\circ} \mathrm{C} ; 2 \mathrm{hr} \text { at } 2100^{\circ} \mathrm{C} \\
& \mathrm{Th}-\mathrm{U}-\mathrm{Si}+\mathrm{C} \rightarrow \mathrm{ThC}_{2}-\mathrm{UC}_{2}-\mathrm{SiC} \ldots 2 \mathrm{hr} \text { at } 2000^{\circ} \mathrm{C}
\end{aligned}
$$

These data show that conversion of the silicide to the carbide is somewhat easier than the conversion of the oxide to the carbide.

Compacts prepared with silicides were slightly more dense than those prepared with oxides (this was expected since there is no evolution of carbon monoxide during the dicarbide formation). As the metal (Th $+U$ ) concentration of the compacts was increased from 0 to $35 \mathrm{wt}-\%$, the densities of the oxide compacts increased from 1.9 to $2.6 \mathrm{~g} / \mathrm{cm}^{3}$, whereas the densities of silicide compacts increased from 1.9 to $2.7 \mathrm{~g} / \mathrm{cm}^{3}$ (see Fig. 24). All compacts were of good appearance.

The results of these experiments demonstrated that fuel compacts could be prepared with 0 to $40 \mathrm{wt}-\%$ metal (the range of fuel loadings in the HTGR) by using either oxides or silicides as starting materials.

A composition containing $7.4 \mathrm{wt}-\%$ silicon was chosen for irradiation study. This silicon content was high enough for easy grinding, yet not so high as to constitute a major addition to the fuel. Also, this composition appeared densest on metallographic examination. Figure 25 is a photomicrograph of the crushed alloy before sieving, Fig. 26 illustrates the structure of the alloy, and Fig. 27 shows the converted carbide particles in the graphite matrix.

Because of the possibility of vapor-phase migration of thorium, uranium, and silicon at high temperatures, the vapor pressures of the metals over their carbides in graphite were calculated from hightemperature free energy and metal vapor-pressure data. The results are 


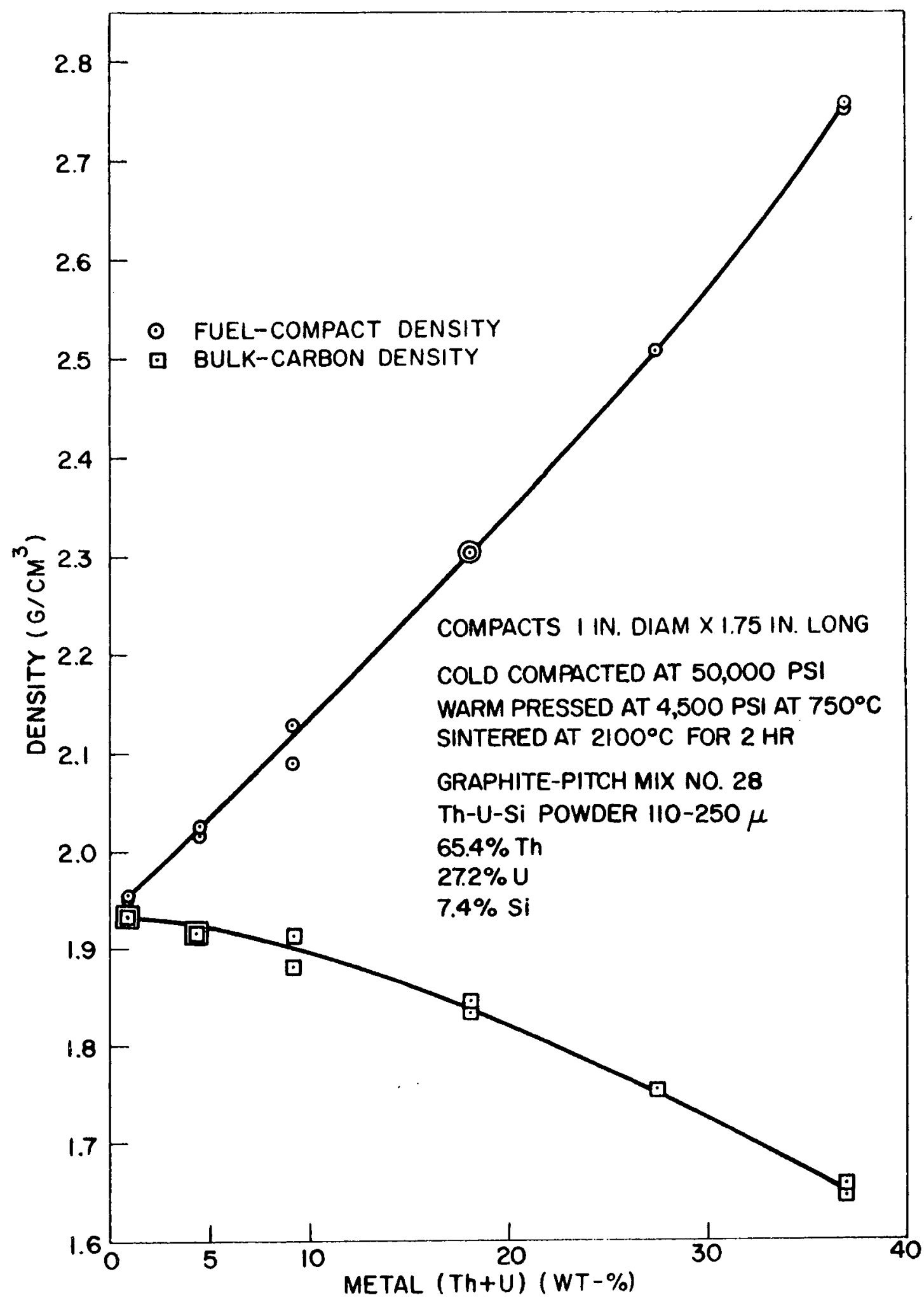

Fig. 24--Fuel-compact density versus metal ( $T h+U)$ content for compacts prepared from Th-U -Si 


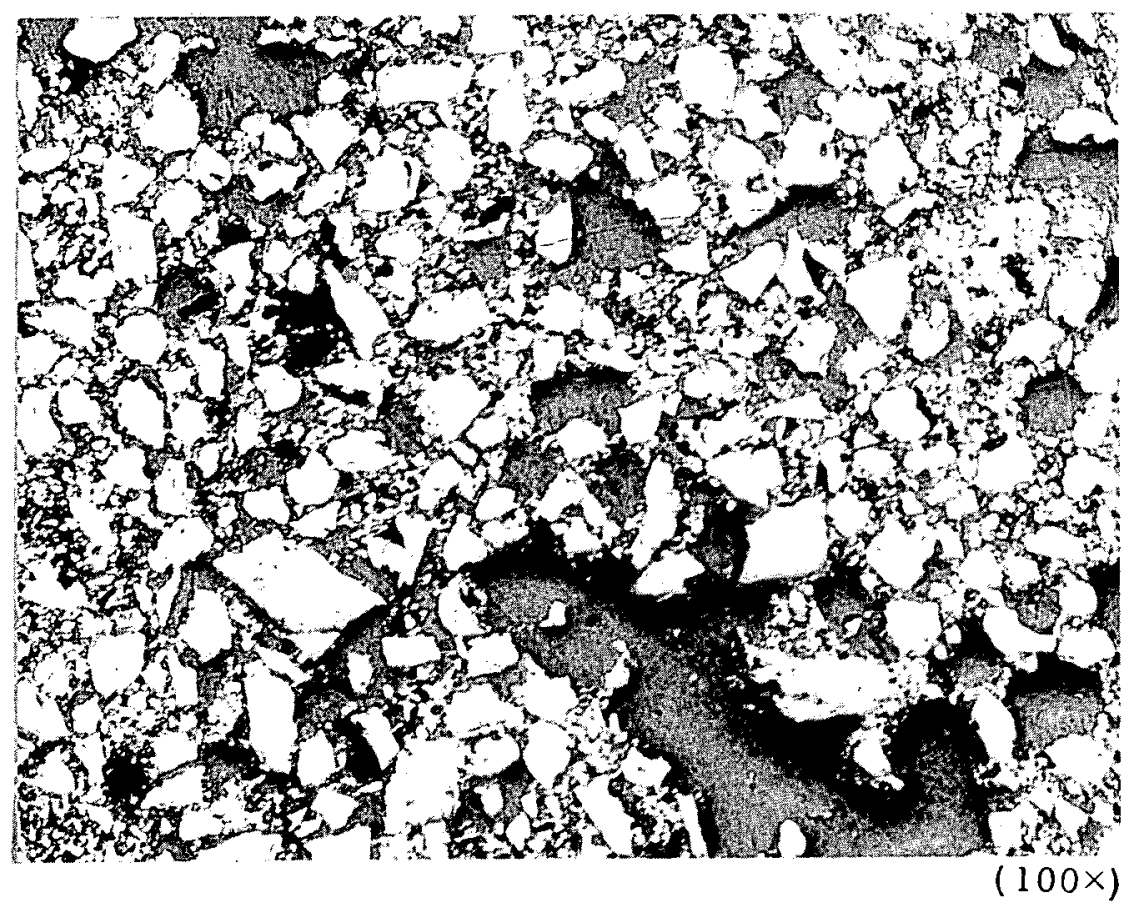

Fig. 25--Photomicrograph of Th-U-Si $17.4 \% \mathrm{Si}$, $\mathrm{Th}: \mathrm{U}=5: 2$ ) arc melted and crushed (not etched) 

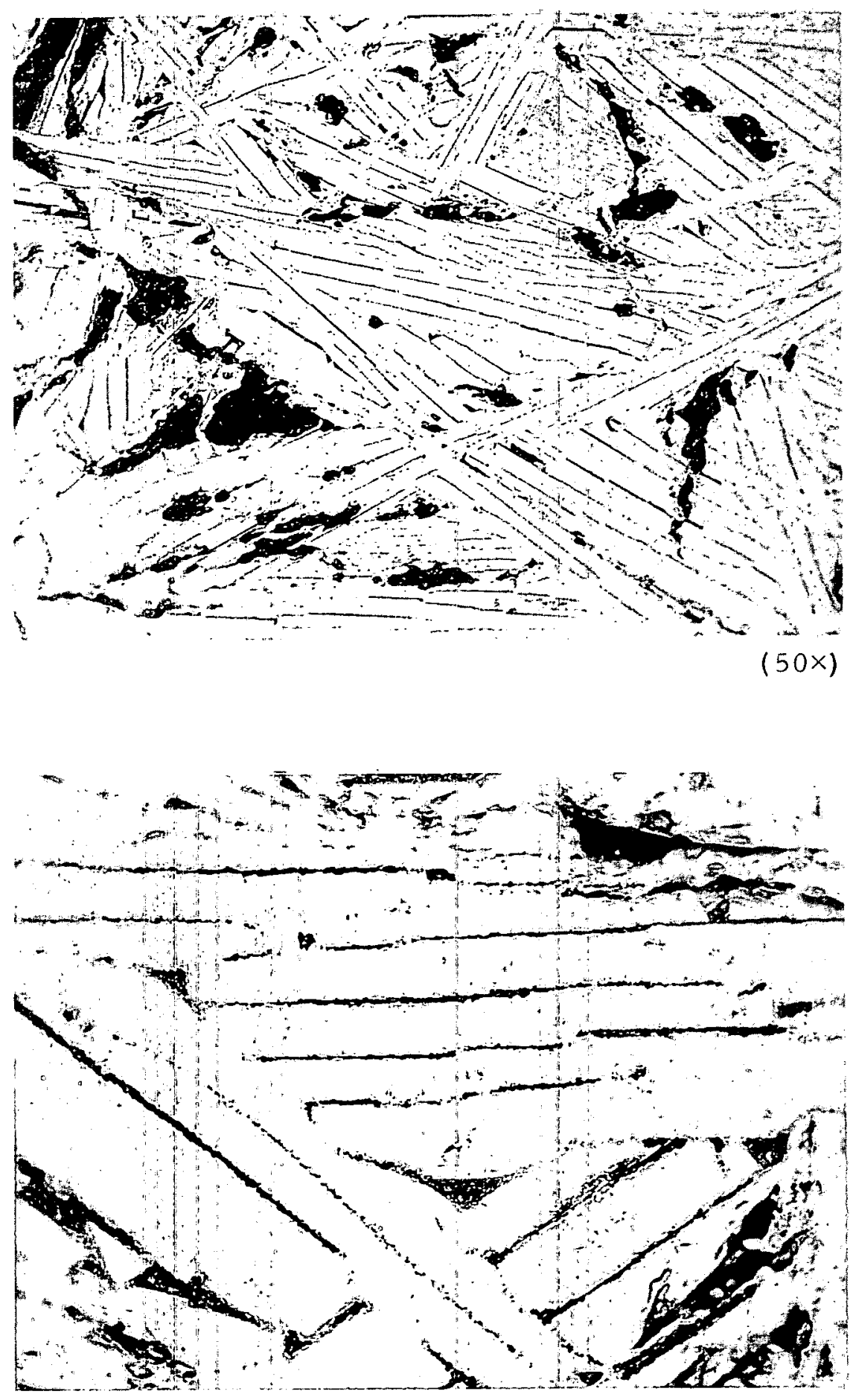

$(250 \times)$

Fig. 26--Photomicrographs of Th-U-Si (7.4\% Si, $\mathrm{Th}: \mathrm{U}=5: 2$ ) prepared by arc melting (etched with $\mathrm{HNO}_{3}, \mathrm{HF}, \mathrm{H}_{2} \mathrm{O}$ ) 


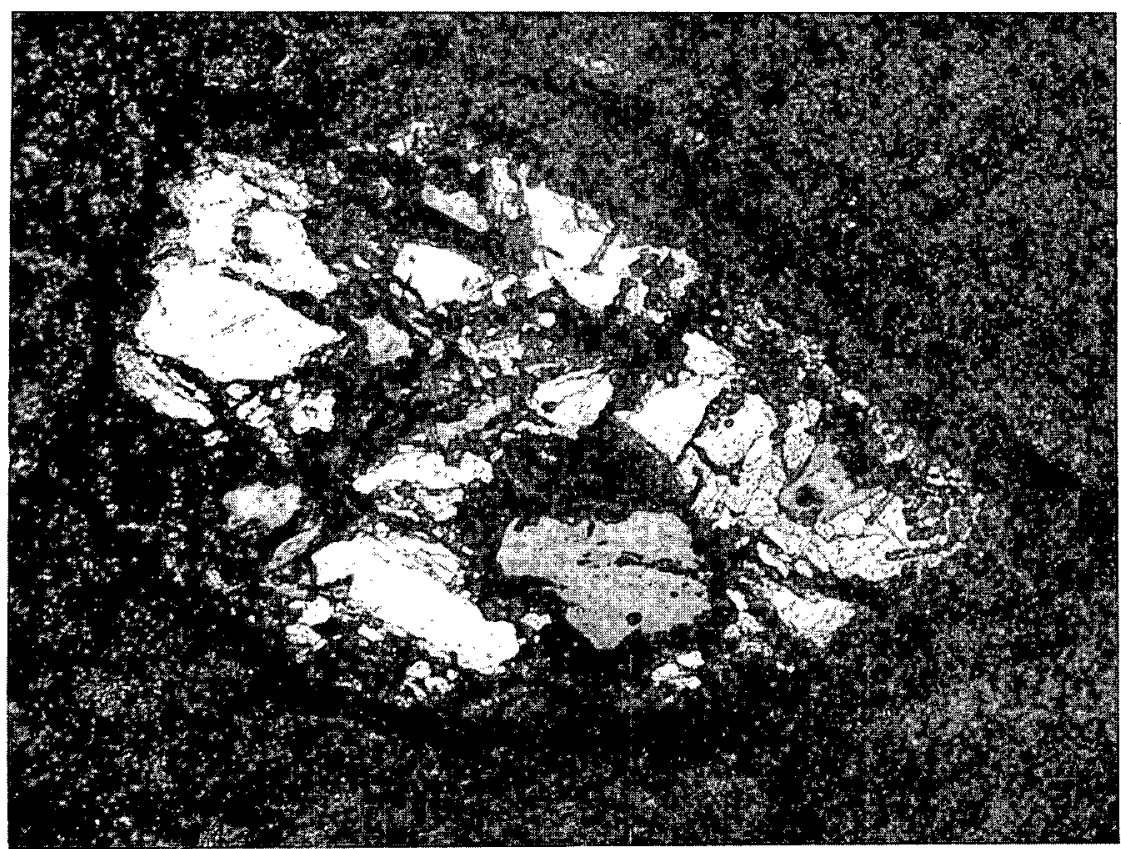

$(250 \times)$

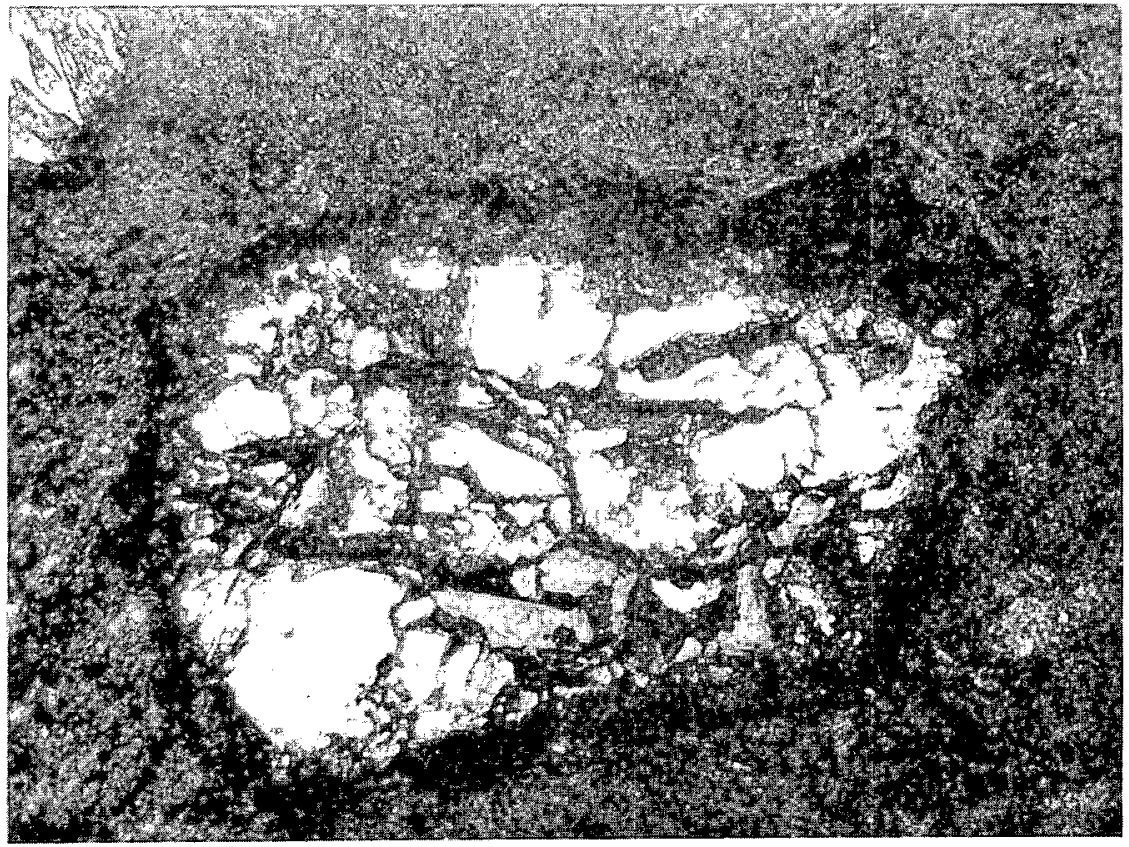

$(250 \times)$

Fig. 27--Photomicrographs of $\mathrm{ThC}_{2}-\mathrm{UC}_{2}-\mathrm{SiC}$ fuel particles in a graphite-matrix fuel compact formed by in situ conversion of $\mathrm{Th}-\mathrm{U}-\mathrm{Si}$ particles $(7.4 \% \mathrm{Si}$, $\mathrm{Th}: \mathrm{U}=5: 2$ ) 
shown in Fig. 28. It can be seen that the vapor pressure of uranium over $\mathrm{UC}_{2}$ is higher than that of thorium over. $\mathrm{ThC}_{2}$, and that the vapor pressure of silicon over $\mathrm{SiC}$ is quite high. Hence, vapor-phase transport of silicon from silicide fuels might be expected at maximum HTGR operating temperatures. This expectation was confirmed by heating a compact containing silicide fuel at $1900^{\circ} \mathrm{C}$ in vacuo. Over one-fourth of the silicon originally present was lost in $200 \mathrm{hr}$.

M. Bowman ${ }^{(6)}$ found that the vapor pressure of U over UC was lowered in UC-Z $\mathrm{rC}$ solid solutions. The data in Fig. 28 indicate that $\mathrm{NbC}$ might also be useful for lowering the vapor pressure. (Unfortunately, neither niobium nor zirconium produce friable alloys, when alloyed with thorium and uranium, as does silicon.) Therefore, various mixtures of silicon, zirconium, and niobium with thorium and uranium were prepared by arcmelting and were studied in order to produce a mixture of low volatility that would still retain the desirable processing properties of silicon.

Some vapor-pressure tests were made in order to check the volatility of silicon in these silicide fuels. Crushed mixtures of various compositions were heated in open-top graphite crucibles in vacuo at $2000^{\circ} \mathrm{C}$, and weight losses were determined at temperature after 2 and $8 \mathrm{hr}$. The data (see Fig. 29) show that the rate of weight loss is reduced by a factor of three by the addition of 10 or $20 \mathrm{wt}-\% \mathrm{NbC}$ or $10 \mathrm{wt}-\% \mathrm{ZrC}$. Vapor pressures of silicon at $2000^{\circ} \mathrm{C}$ were calculated from the weight loss data shown in Fig. 29 and the results are listed in Table 7 .

These data show that $10 \% \mathrm{Zr}$ was the most effective in lowering the vapor pressure of silicon. The improvement, however, was not substantial enough; the vaporization rate of the silicon was too high for use in the HTGR (maximum predicted fuel temperature is $1800^{\circ} \mathrm{C}$ and the expected fuel life is three years). Studies of silicide fuels were therefore discontinued.

Coated Carbide Fuel

$(\mathrm{Th}, \mathrm{U}) \mathrm{C}_{2}$ is extremely reactive in air ${ }^{(7)}$ and fuel compacts containing unprotected $(\mathrm{Th}, \mathrm{U}) \mathrm{C}_{2}$ disintegrate by hydrolysis after a few hours exposure 


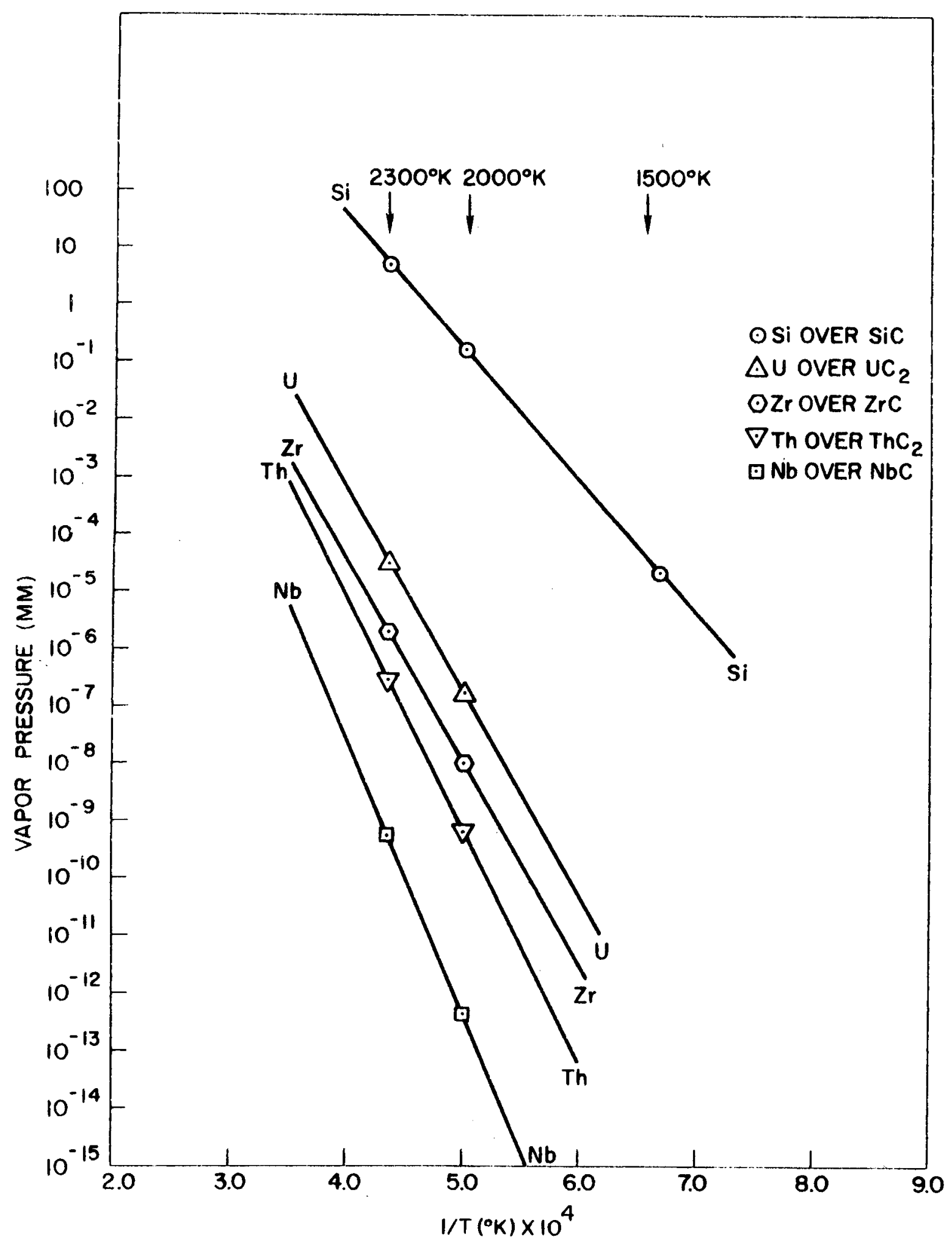

Fig. 28--Vapor pressure of silicon, uranium, zirconium, thorium, and. niobium over their carbides 


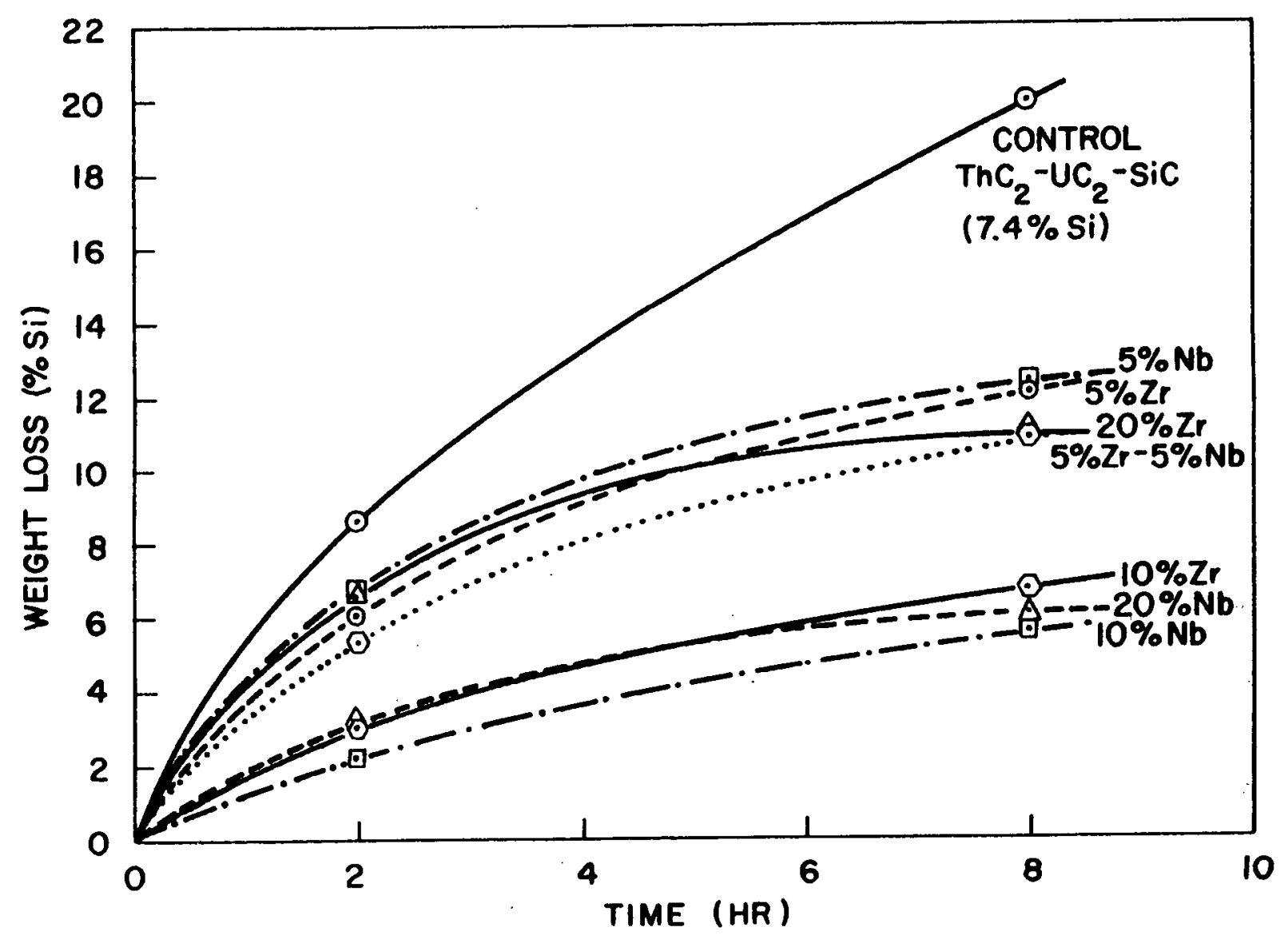

Fig. 29--Weight losses from arc-melted and crushed $\mathrm{ThC}_{2}-\mathrm{UC}_{2}-\mathrm{SiC}$ fuel after heating at $2000^{\circ} \mathrm{C}$ in vacuo as a function of the addition of various amounts of $\mathrm{ZrC}$ and $\mathrm{NbC}$ 
Table 7

VAPOR PRESSURES OF SILICON OVER VARIOUS CARBIDE MIXTURES AT $2000^{\circ} \mathrm{C}$

$(\mathrm{Si}=7.4 \mathrm{wt}-\%$ of $\mathrm{Th}+\mathrm{U}+\mathrm{Si})$

\begin{tabular}{|c|c|}
\hline Composition & $\begin{array}{c}\text { Vapor Pressure } \\
(\mathrm{atm}) \\
\end{array}$ \\
\hline$\ldots \cdot \cdots \cdot \cdots$ & . . $1.3 \times 10^{-6}$ \\
\hline$-\mathrm{UC}_{2}-\mathrm{SiC}$ & . $1.9 \times 10^{-6}$ \\
\hline $\mathrm{ThC}_{2}-\mathrm{UC}_{2}-\mathrm{SiC}-\mathrm{ZrC}, 5 \% \mathrm{Zr}$ & . 2. $1 \times 10^{-6}$ \\
\hline $\mathrm{ThC}_{2}-\mathrm{UC}_{2}-\mathrm{SiC}-\mathrm{ZrC}, \quad 10 \% \mathrm{Zr}$ & . $0.8 \times 10^{-6}$ \\
\hline $\mathrm{ThC}_{2}-\mathrm{UC}_{2}-\mathrm{SiC}-\mathrm{ZrC}, 20 \% \mathrm{Zr} \ldots$ & . . $1.7 \times 10^{-6}$ \\
\hline $\mathrm{ThC}_{2}-\mathrm{UC}_{2}-\mathrm{SiC}-\mathrm{NbC}, 5 \% \mathrm{Nb}$ & . $2.0 \times 10^{-6}$ \\
\hline $\mathrm{ThC}_{2}-\mathrm{UC}_{2}-\mathrm{SiC}-\mathrm{NbC}, \quad 10 \% \mathrm{Nb} \ldots$ & . $1.1 \times 10^{-6}$ \\
\hline $\mathrm{ThC}_{2}-\mathrm{UC}_{2}-\mathrm{SiC}-\mathrm{NbC}, 20 \% \mathrm{Nb} \ldots$ & . $1.2 \times 10^{-6}$ \\
\hline $\mathrm{ThC}_{2}-\mathrm{UC}_{2}-\mathrm{SiC}-\mathrm{NbC}-\mathrm{ZrC}, 5 \% \mathrm{Zr}$ and $5 \% \mathrm{Nb}$ & . $1.9 \times 10^{-6}$ \\
\hline
\end{tabular}

to laboratory air. Thus, fuel compacts produced by the in situ conversion of $(\mathrm{Th}, \mathrm{U}) \mathrm{O}_{2}$ must be handled and stored in a dry, inert atmosphere. In order to overcome this problem, the use of carbon coatings on the individual $(\mathrm{Th}, \mathrm{U}) \mathrm{C}_{2}$ particles was investigated.

Battelle Memorial Institute had developed a process for coating of fuel particles with pyrolytic carbon, ${ }^{(8)}$ and this work has been extended at General Atomic. (9)(10) Testing of the coated carbides showed not only that the coatings rendered the fuel compacts inert to moisture, but that they also substantially improved fission-product retention. In addition, since no carbon is consumed from the matrix by a conversion reaction, the integrity of the fuel-particle-graphite-matrix interface was improved and the final sintering time and temperature for the compacts were reduced.

Coating of the particles is performed in a fluid-bed reactor (see Fig. 30) at $1400^{\circ} \mathrm{C}$. Helium is the fluidizing gas and acetylene or methane furnish the carbon. Photomicrographs of coated particles are shown in Fig. 31.

Compacts with carbon-coated carbide particles are prepared by the warm-press and sinter process. Since cold-pressing tends to break the coatings on the particle, this step is eliminated. A comparison of the 


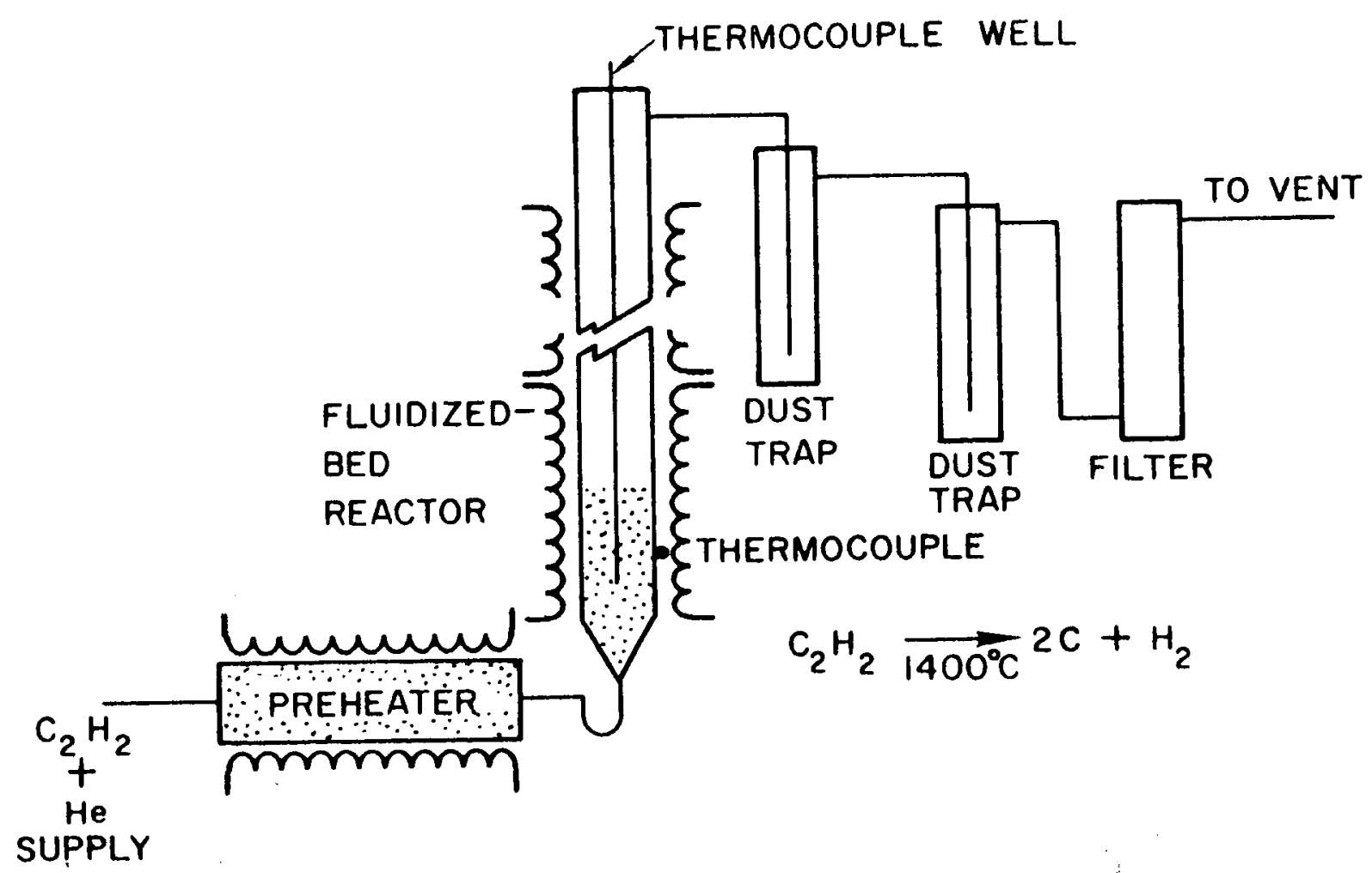

Fig. 30--Schematic diagram of apparatus for the preparation of carbon-coated $\mathrm{UC}_{2}$ 


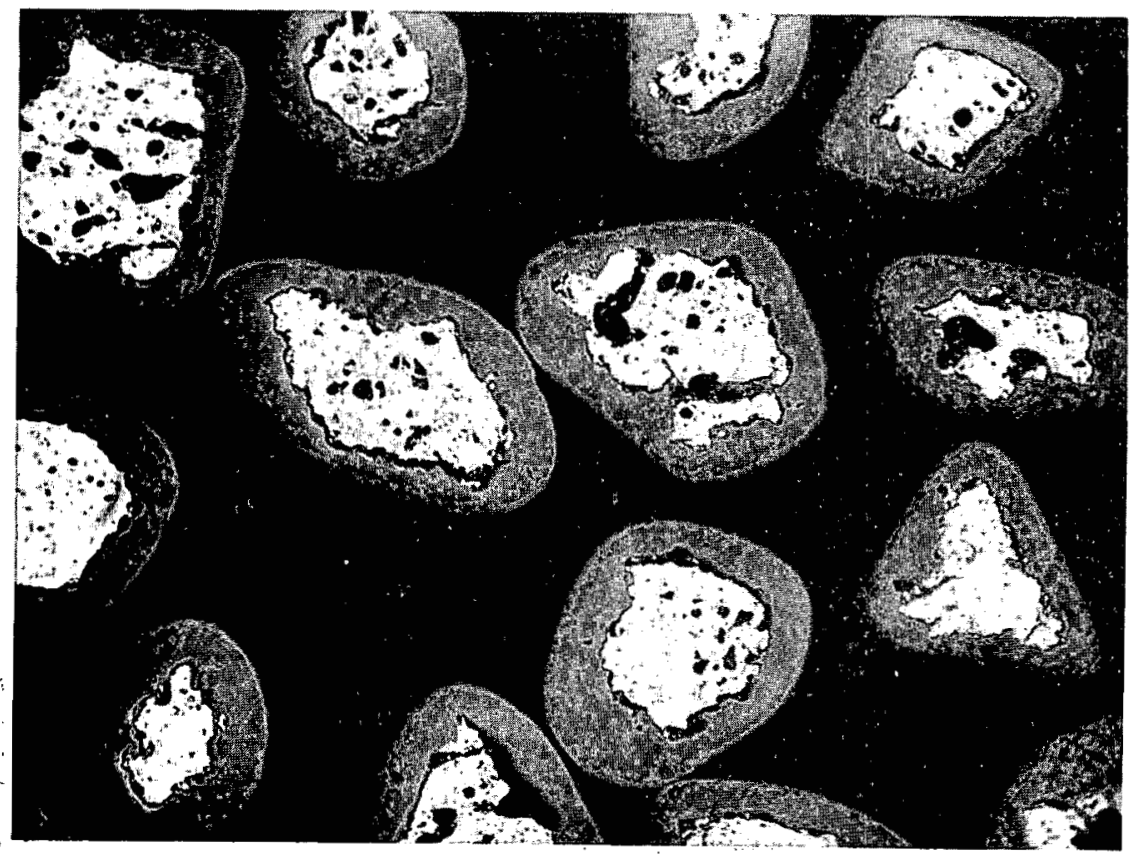

$(75 \times)$

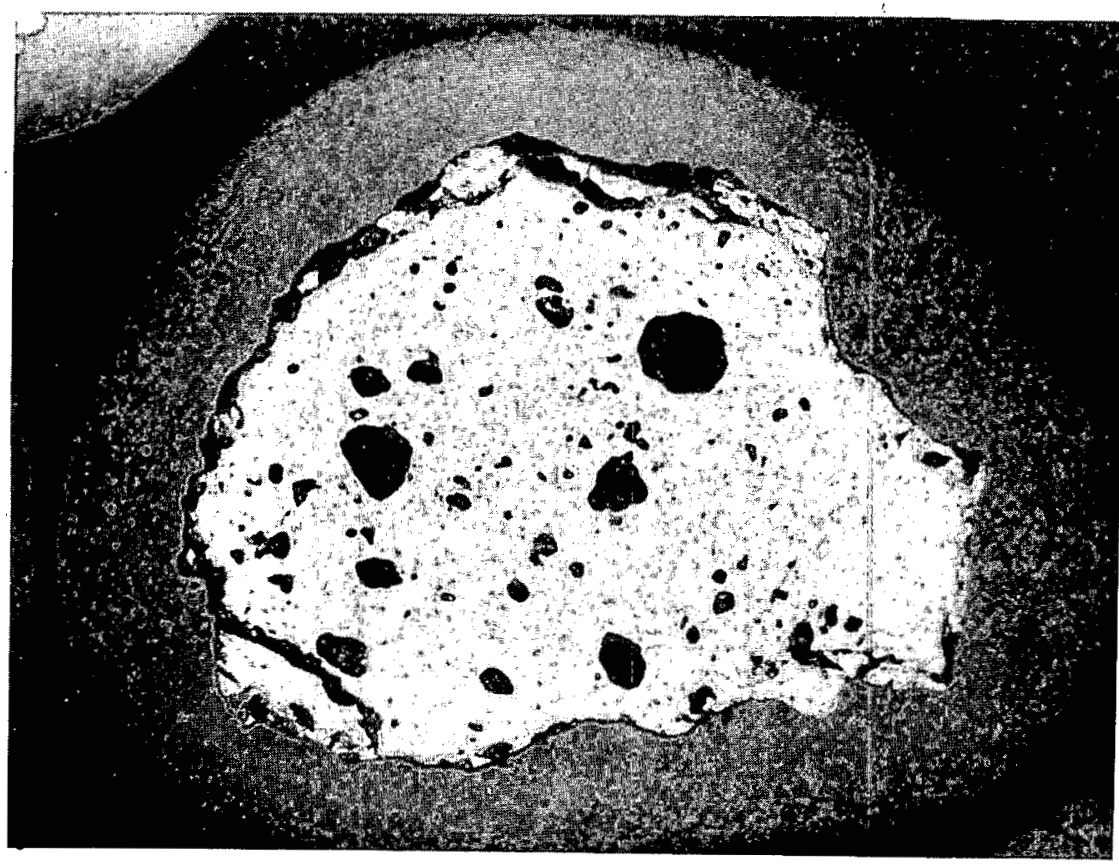

$(250 \times)$

Fig. 31--Photomicrographs of pyrolytic-carboncoated ( $\mathrm{Th}, \mathrm{U}) \mathrm{C}_{2}$ fuel particles; coating deposited from acetylene at $1400^{\circ} \mathrm{C}$ 
process used with oxide fuel (converted oxide process) and that used with coated carbides (coated carbide process) is given in Fig. 32 . Following warm-pressing, the compacts are given a stabilizing heat treatment to complete the removal of volatiles and to minimize dimensional changes resulting from subsequent thermal treatments. Typical dimensional changes resulting from heating the compacts after warm-pressing are shown in Fig. 33.

Photomicrographs of compacts with pyrolytic-carbon-coated (Th, U) $\mathrm{C}_{2}$ fuel particles are shown in Figs. 34 and 35. The improved contact between particle and matrix may be noted by comparison with Fig. 21. Typical full-sized compacts are shown in Figs. 36 and 37.

A coating thickness equivalent to several recoil ranges is desirabie to keep a large portion of the coating relatively free from the intense fissionfragment damage that the carbon receives immediately adjacent to the carbide particle. Thick coatings are also more resistant to stresses developed by fission-gas pressure within the particle. However, if thick coatings are used on small fuel particles, the coated particles occupy a large volume for a small amount of fuel. Since it is desirable to maintain a continuous matrix of warm-pressed graphite around the fuel particles, the coated particles should not occupy over 30 vol-\% of the compact. Hence, for HTGR loadings (refer to Table 1) a carbide-particle size greater than $200 \mu$ is required. This permits the use of $50 \mu$ carbon coatings.

PROPERTIES OF WARM-PRESSED AND SINTERED GRAPHITE-MATRIX FUEL COMPACTS

A number of physical and thermal properties have been determined for the graphite-matrix fuel compacts prepared by the warm-press and sinter process described in the previous sections. Also, fairly extensive irradiation and fission-product-retention testing has been conducted with this material. Some typical properties are summarized in Table 8.

Discussions of the test programs and results are presented in the following sections. 

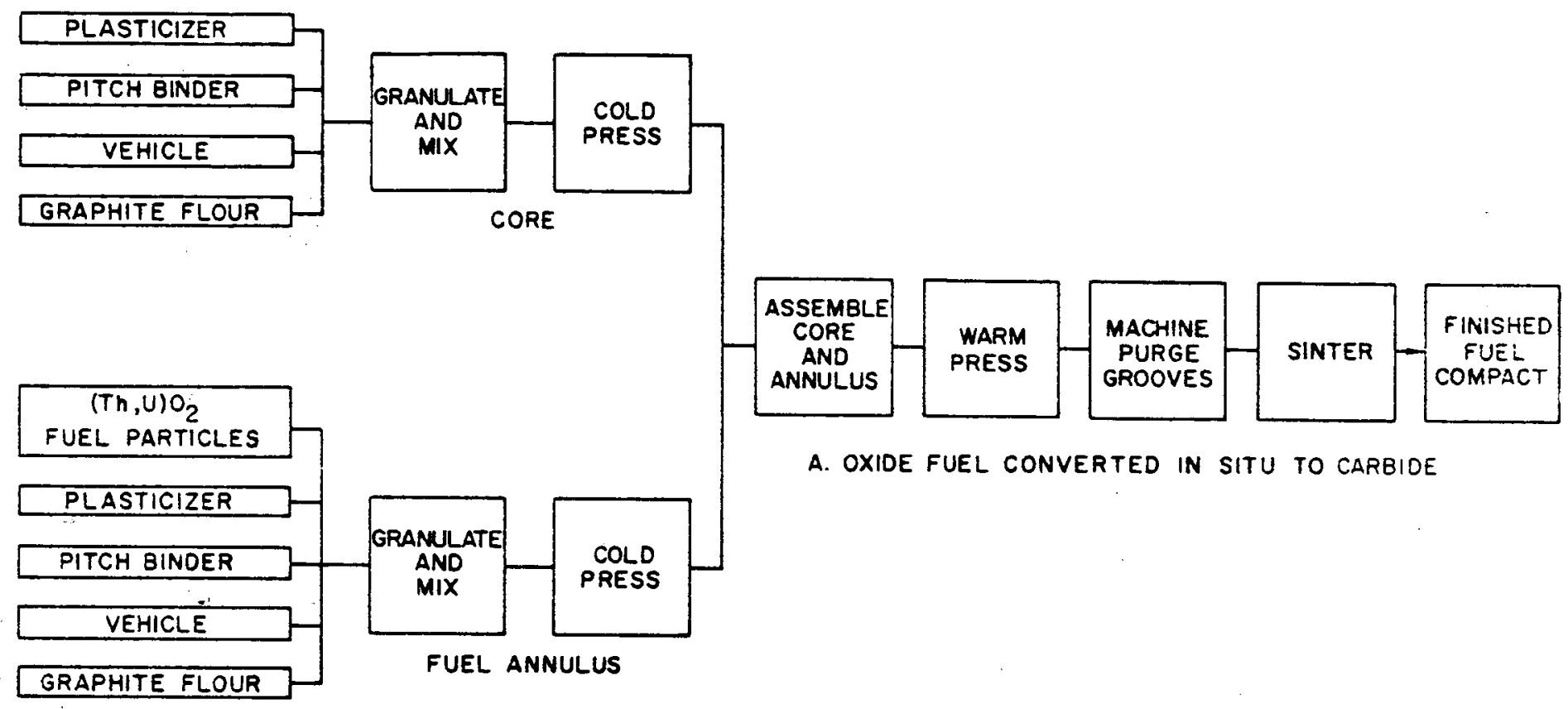

A. OXIDE FUEL CONVERTED IN SITU TO CARBIDE

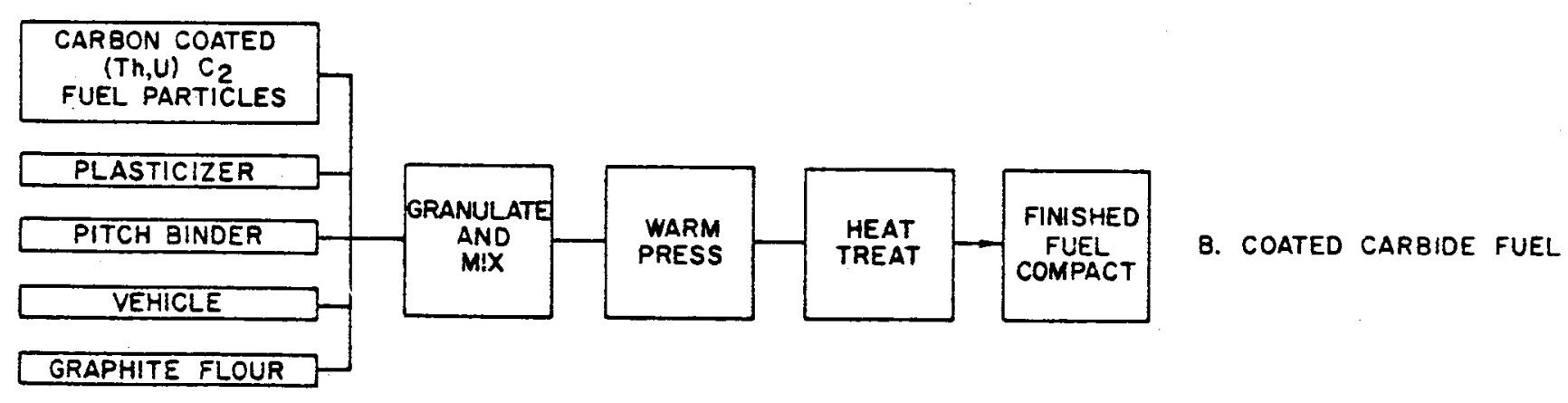

Fig. 32--Fuel-compact fabrication processes 


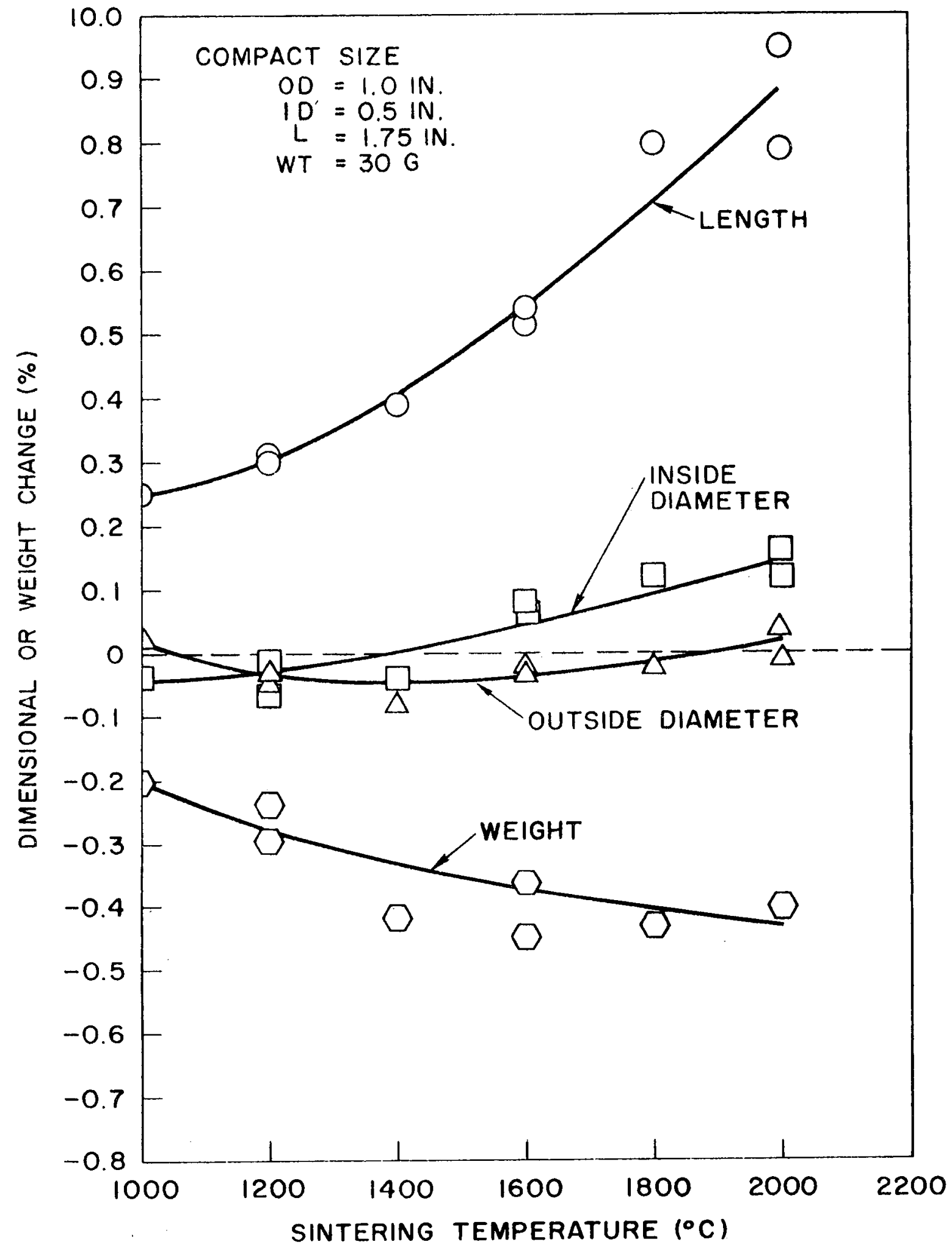

Fig. 33--Weight and dimensional changes resulting from sintering of warm-pressed, annular fuel compacts at various temperatures for $2 \mathrm{hr}$ 


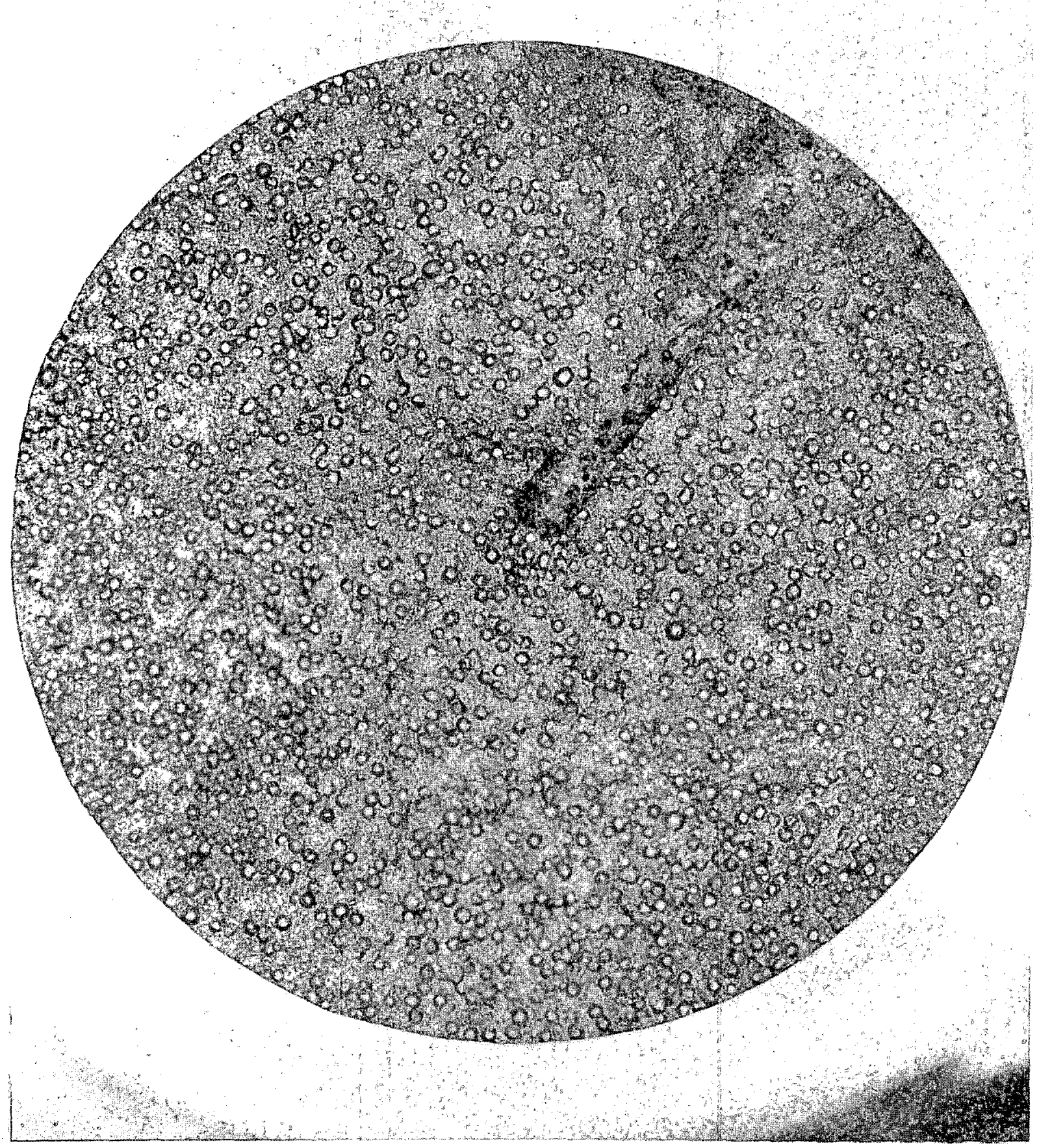

Fig. 34--Sectioned fuel compact containing carbon-coated ( $\mathrm{Th}, \mathrm{U}) \mathrm{C}_{2}$ fuel particles; 1-in. -diameter compact was split by chisel (upper right-hand edge): particles adhered to broken surfaces and did not pull out or break 


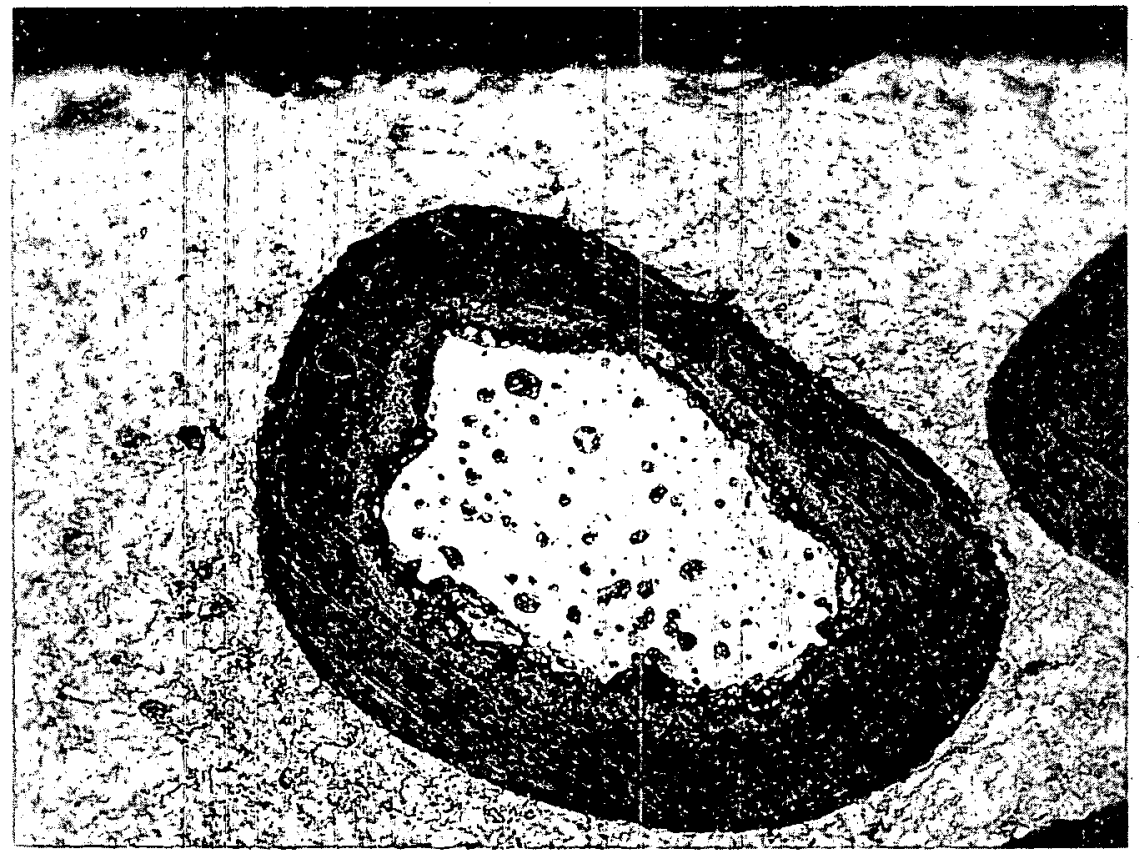

$(250 \times)$

Fig. 35--Pyrolytic-carbon-coated ( Th, U) $\mathrm{C}_{2}$ particle in graphite matrix; note good bond between particle and matrix 


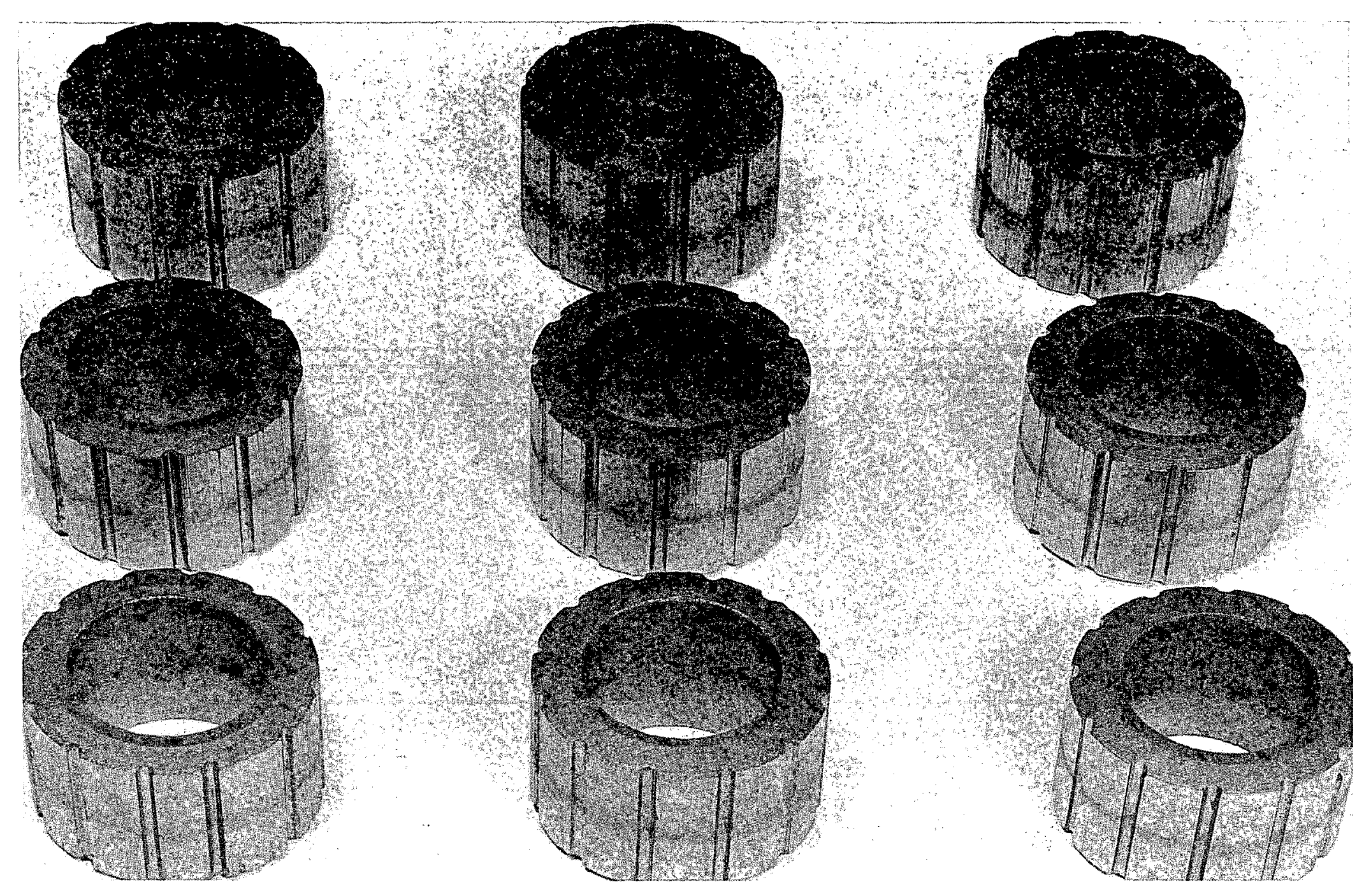

Fig. 36--Annular fuel compacts containing carbon-coated (Th, U) $\mathrm{C}_{2}$ fuel particles; compacts are $2.25 \mathrm{in}$. in outside diameter 


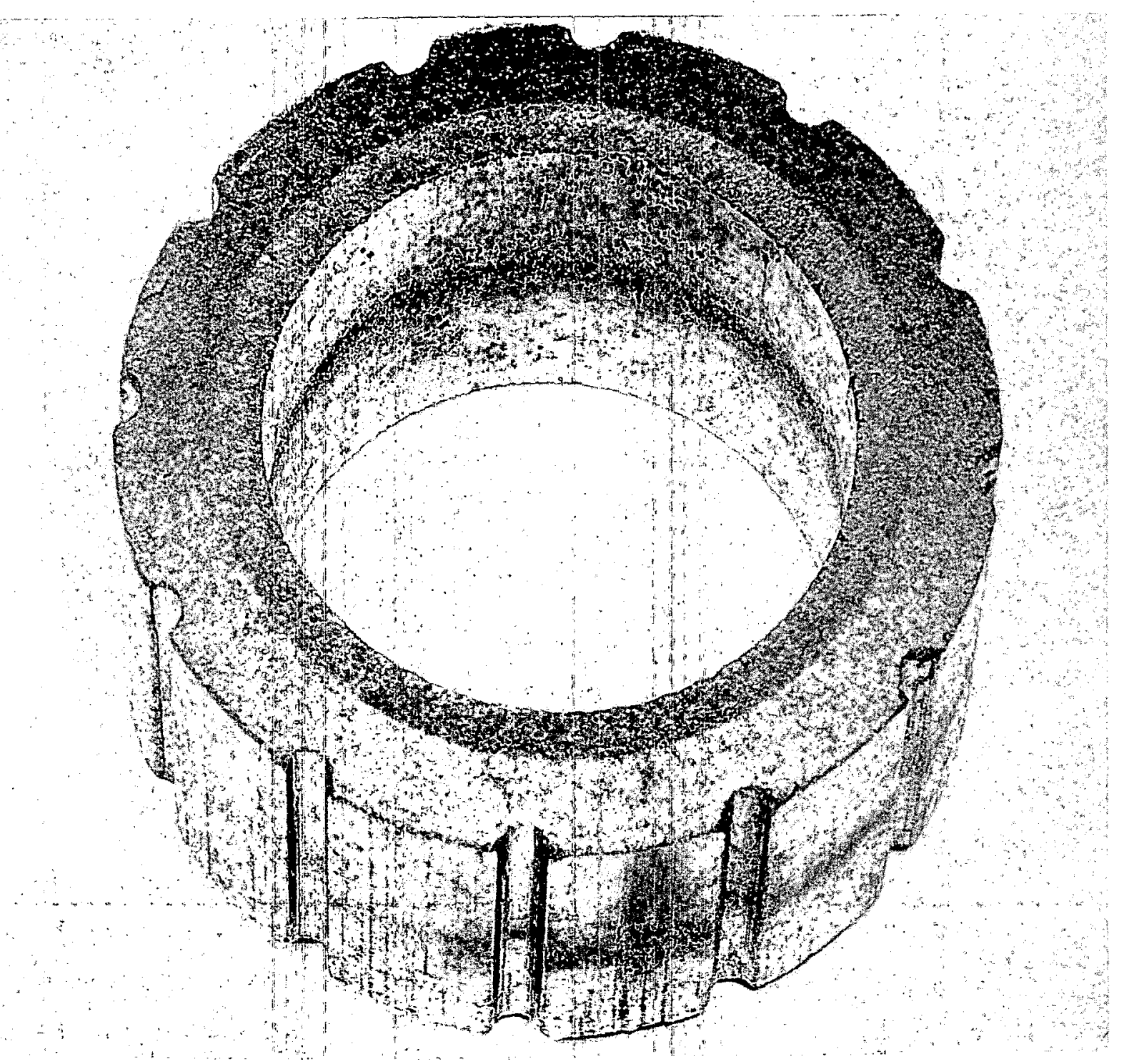

Fig. 37--Annular fuel compact containing carbon-coated (Th, U) $\mathrm{C}_{2}$ particles; compact is $2.25 \mathrm{in}$. in outside diameter 
Table 8

TYPICAL PROPERTIES OF GRAPHITE-MATRIX

FUEL COMPACTS

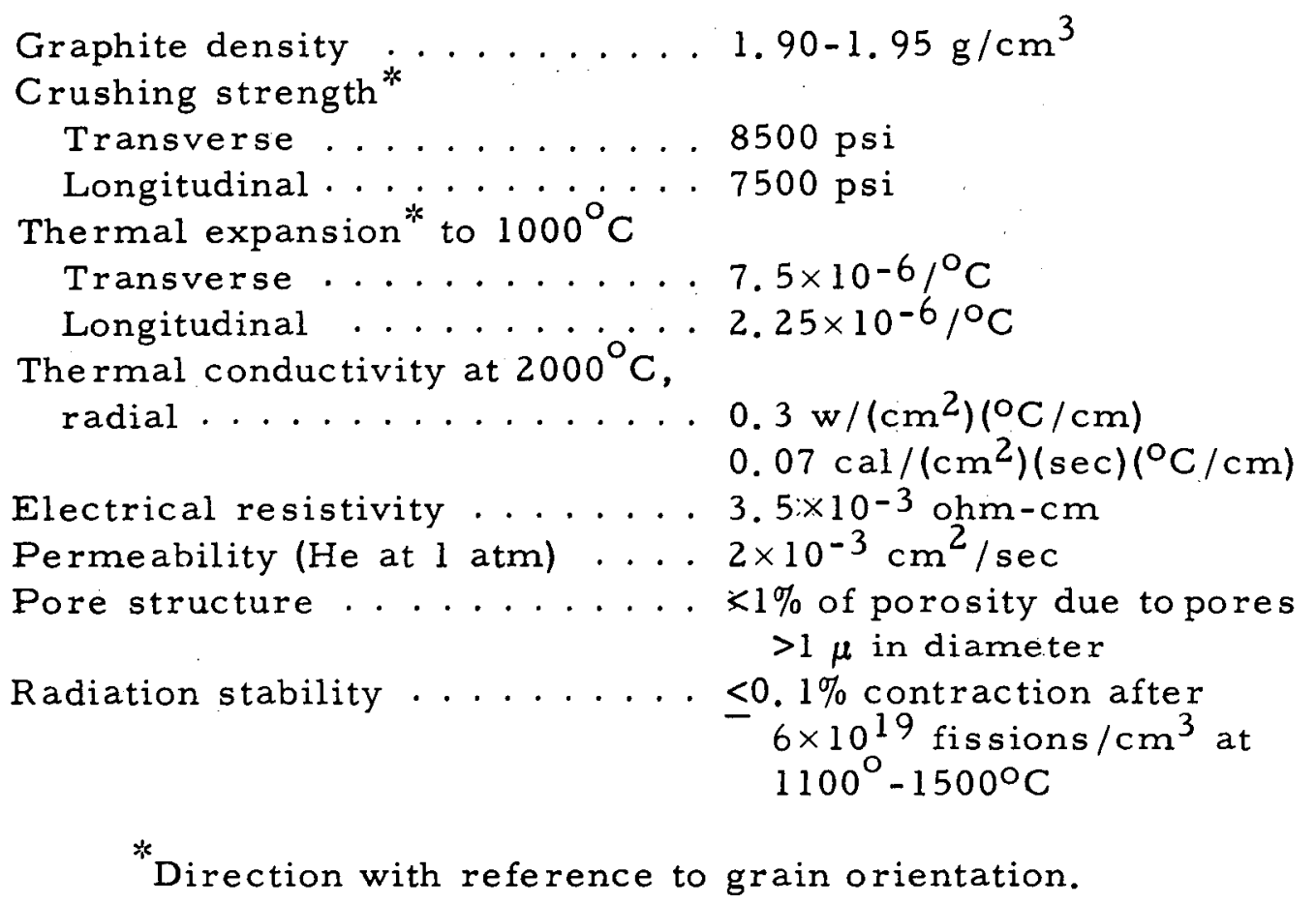

$\underline{\text { Density }}$

As discussed in "Preparation of Compacts by Hot-pressing Techniques," the density of the unfueled graphite matrix may be varied by varying the processing conditions (see Figs. 13, 15, 16, and 17). Values of 1.90 to $1.95 \mathrm{~g} / \mathrm{cm}^{3}$ are generally obtained, although densities of $>2.0 \mathrm{~g} / \mathrm{cm}^{3}$ have been produced. Variations of density with fuel loading are shown in Figs. 22 and 24.

Strength

Crushing strengths were determined by using machined rods whose length-to-diameter ratio was approximately one. Figures 12, 13, 14, and 15 illustrate the variations in strength with processing conditions. Typical crushing-strength values obtained on 1/4-in. -diameter by $1 / 4-$ in. -long samples are 8500 psi transverse (perpendicular to grain orientation and 
parallel to direction of pressing) and 7500 psi longitudinal. Values about 1000 psi lower were obtained on 1 -in. -diameter specimens.

Thermal Expansion

Coefficients of thermal expansion were determined in vacuo with an optical dilatometer over the range from room temperature to $700^{\circ}$ and $1000^{\circ} \mathrm{C}$. Specimens $5 / 32 \mathrm{in}$. in diameter by $1 \mathrm{in}$. or $2 \mathrm{in.}$ long were used. Values for the unfueled graphite matrix gave an isotropy ratio of 3.3 ; the expansion is greatest in the direction of pressing. Fuel-particle size ( $<50 \mu$ to $500 \mu$ ) and fuel loading ( 0 to $22 \mathrm{wt}-\% \mathrm{Th}+\mathrm{U}$ ) had little if anyeffect on the the rmal expansion.

Thermal Conductivity

Heat must be transferred radially from the fuel compacts, and since graphite is anisotropic, it was desirable to measure thermal conductivity in the radial direction. A simple apparatus (see Fig. 38) was used to obtain reasonably good data on laboratory-scale (1-in. -diameter by 2 -in. -long) fuel compacts. The method ${ }^{(11)}$ is based on the resistance heating of the rod-shaped specimen by the longitudinal passage of large currents. Heat is generated uniformly in the sample and is lost from the surface by radiation, resulting in an axial temperature gradient from the center to the outer surface. This temperature gradient is inversely proportional to the thermal conductivity of the material. A graphite sample of known thermal conductivity is used as a reference.

Fueled and unfueled graphite-matrix compacts were found to have the rmal conductivities between 0.07 and $0.08 \mathrm{cal} /\left(\mathrm{cm}^{2}\right)(\mathrm{sec})\left({ }^{\circ} \mathrm{C} / \mathrm{cm}\right)$ over the temperature range from $1400^{\circ}$ to $2000^{\circ} \mathrm{C}$. The final heat-treat temperature (in the range from $1400^{\circ}$ to $2100^{\circ} \mathrm{C}$ ) of the compact had little if any effect on the thermal conductivity.

Thermal Stress and Shock Resistance

Of the many severe thermal-cycle stress and shock tests that these 


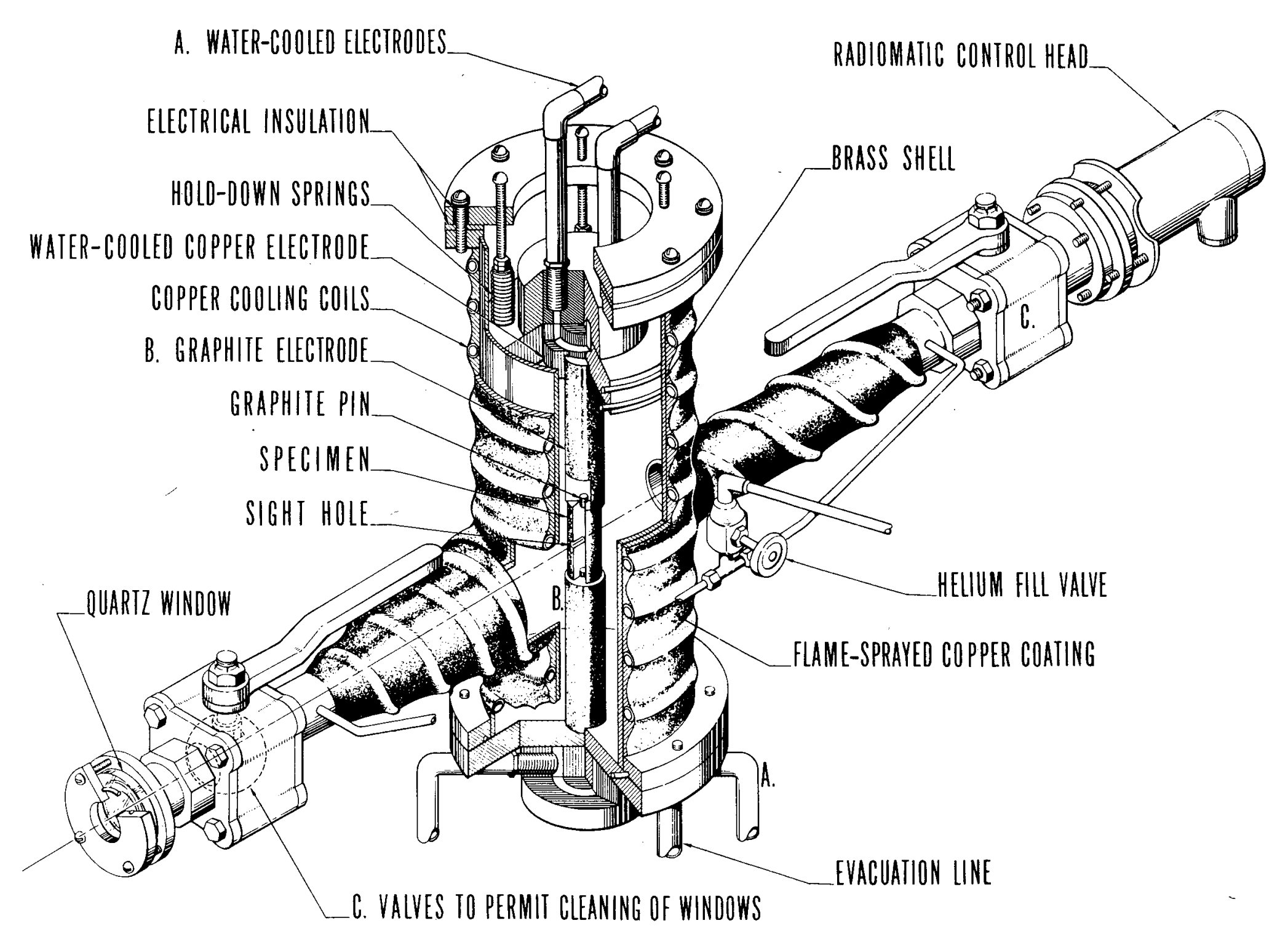

o

Fig. 38--Electric (resistance) heating apparatus for measuring thermal conductivity of graphite specimens 
compacts have been subjected to, none has caused failure (cracking, spalling, etc.). In this respect, the compacts are similar to a high-density, petroleumcoke base, pitch-bonded graphite. Compacts have been heated both directly (by resistance) and indirectly (in a furnace) to temperatures as high as $2600^{\circ} \mathrm{C}$. In several instances compacts were repeatedly heated from room temperature to $2600^{\circ} \mathrm{C}$ in less than $1 \mathrm{~min}$ without failure.

\section{Electrical Resistivity}

The room-temperature electrical resistivity of the unfueled compacts is $3.5 \pm 0.1 \times 10^{-3} \mathrm{ohm}-\mathrm{cm}$; it is insensitive to the final heat-treat temperature of the compact over the range $1400^{\circ}$ to $2150^{\circ} \mathrm{C}$. Prolonged heating at $2150^{\circ} \mathrm{C}$, however, reduces the resistivity by one-third, and the addition of $(T h, U) C_{2}$ fuel to the compacts had a similar effect.

\section{Permeability}

Pressure-decay techniques were used to measure the helium permeability of the fuel compacts. Figure 39 shows the variation in permeability with compact density. Since low permeability was a desirable attribute (to increase fission-product retention), high compact densities were desir-able.

\section{$\underline{\text { Porosimetry }}$}

Pore spectrums were determined with an hydraulic, mercuryintrusion porosimeter. Curves of the differential accessible volume, $d V(r) / d r$, expressed as a percent of the sample bulk volume per micron, are shown in Figs. 40 and 41 . The long tail at high pore radii found with most commercial graphites ${ }^{(12)}$ is noticeably lacking with the warm-pressed and sintered graphite fuel matrix. This tight, uniform pore structure has been found-ideally suited for impregnation treatments to further reduce permeability. The effects on the pore spectrums of additions of ethyl cellulose may also be seen in Figs. 40 and 41 . The uniform structure revealed by the porosimetry data is visually confirmed in Fig. 42, which shows the graphite fuel matrix. 


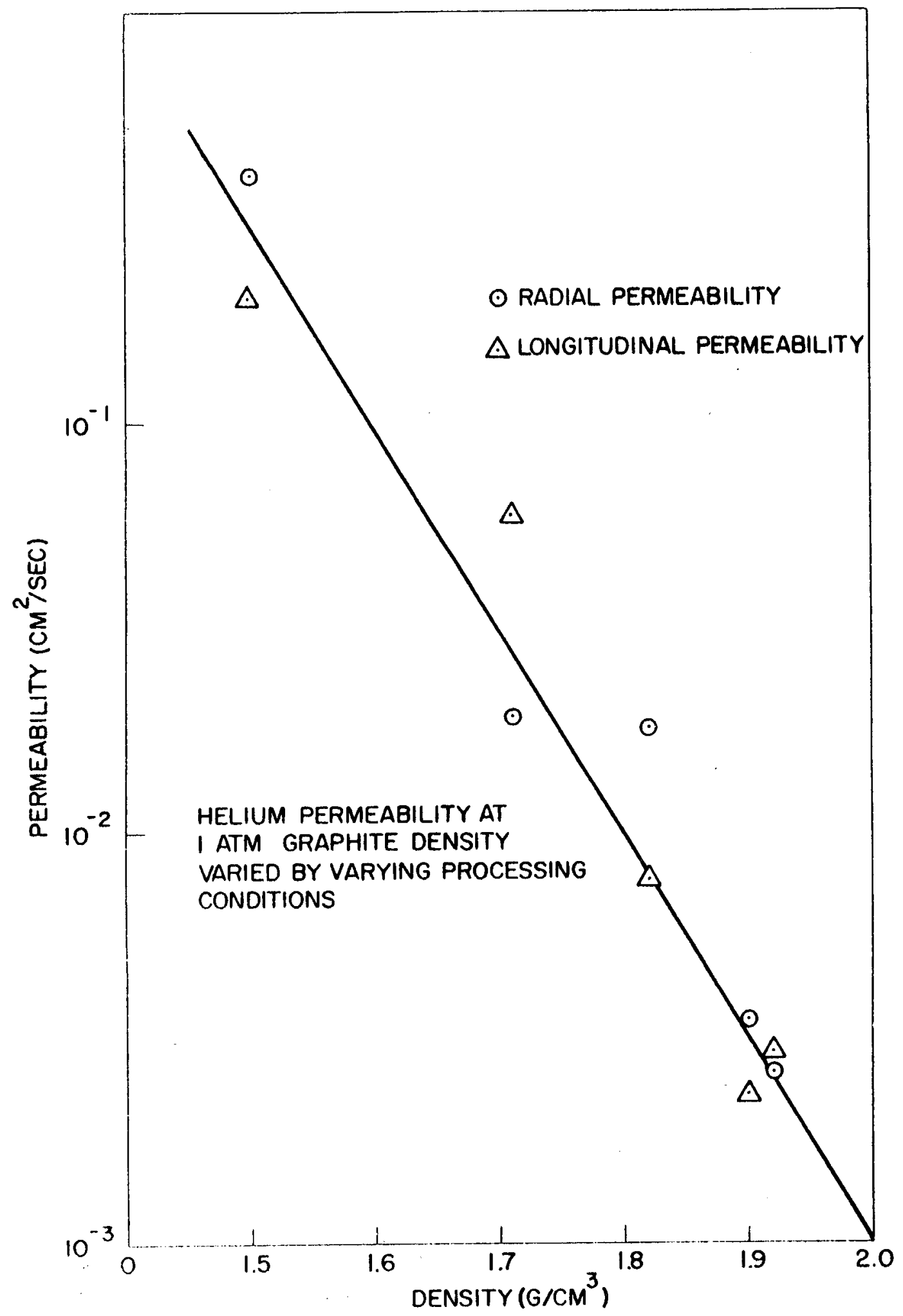

Fig. 39--Permeability versus density of graphite-matrix material for the HTGR fuel compacts 


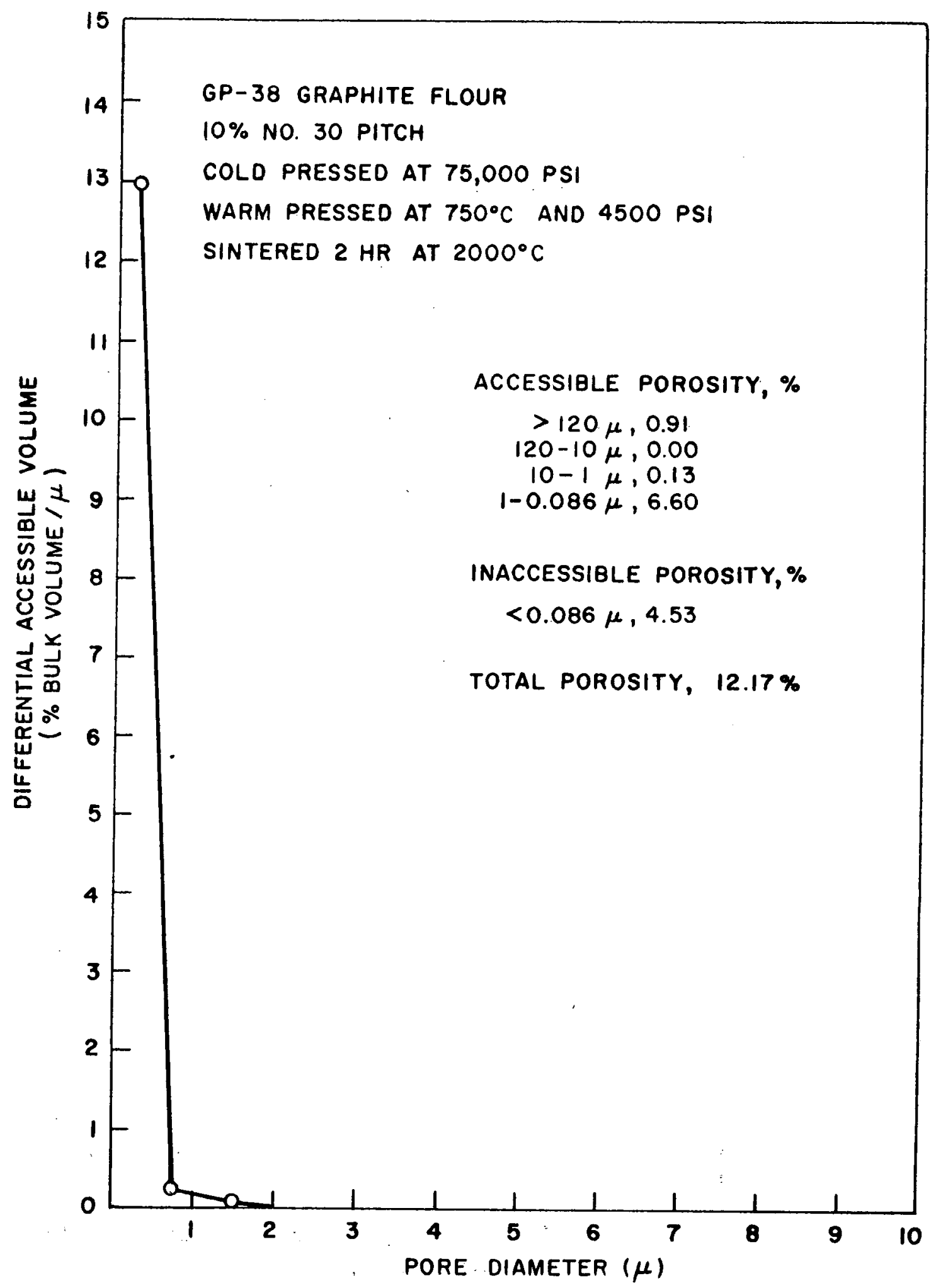

Fig. 40--Pore spectrum of warm-pressed and sintered graphite fuel matrix 
64

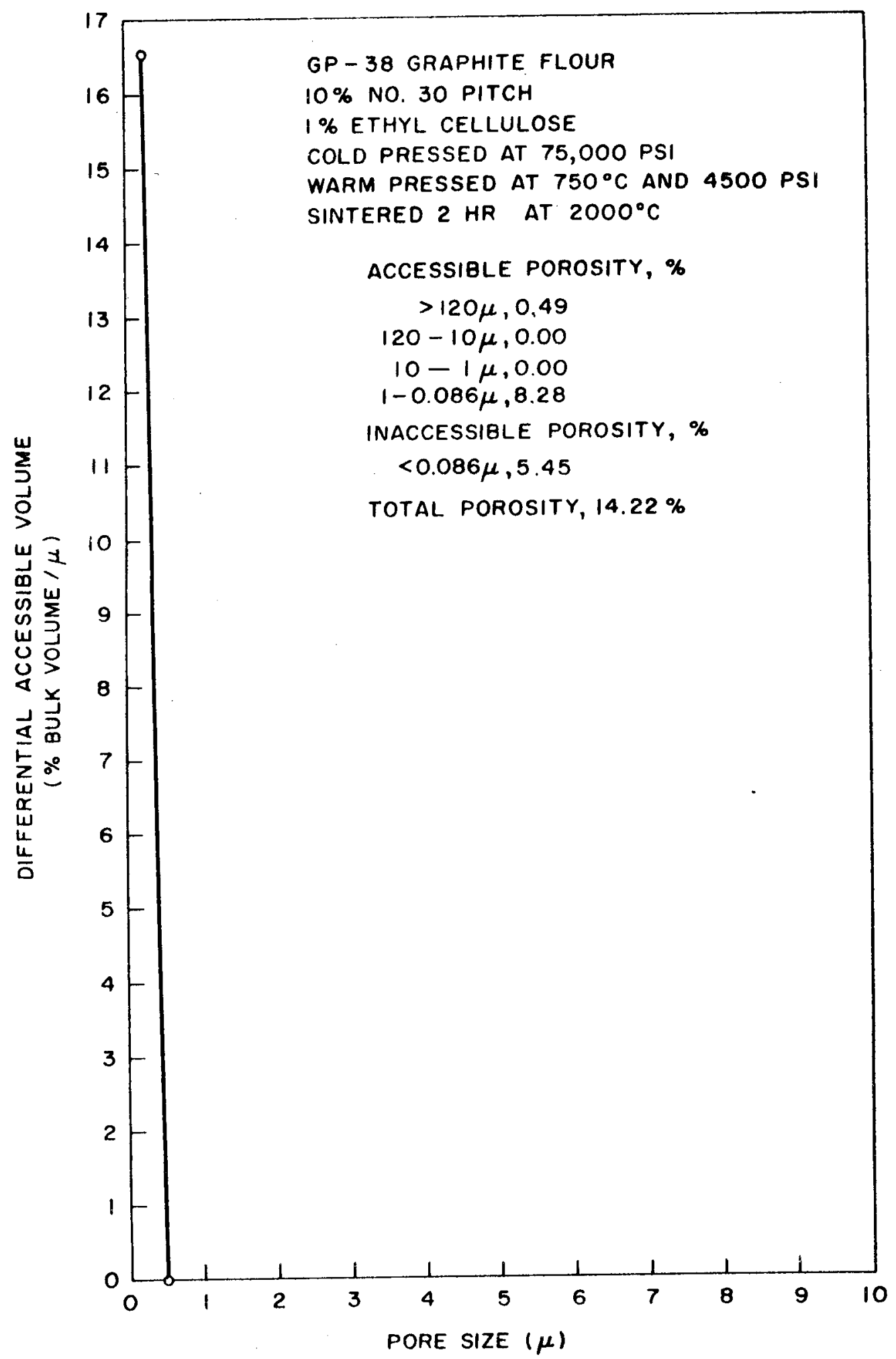

Fig. 41--Pore spectrum of warm-pressed and sintered graphite fuel matrix containing $1 \%$ ethyl cellulose 


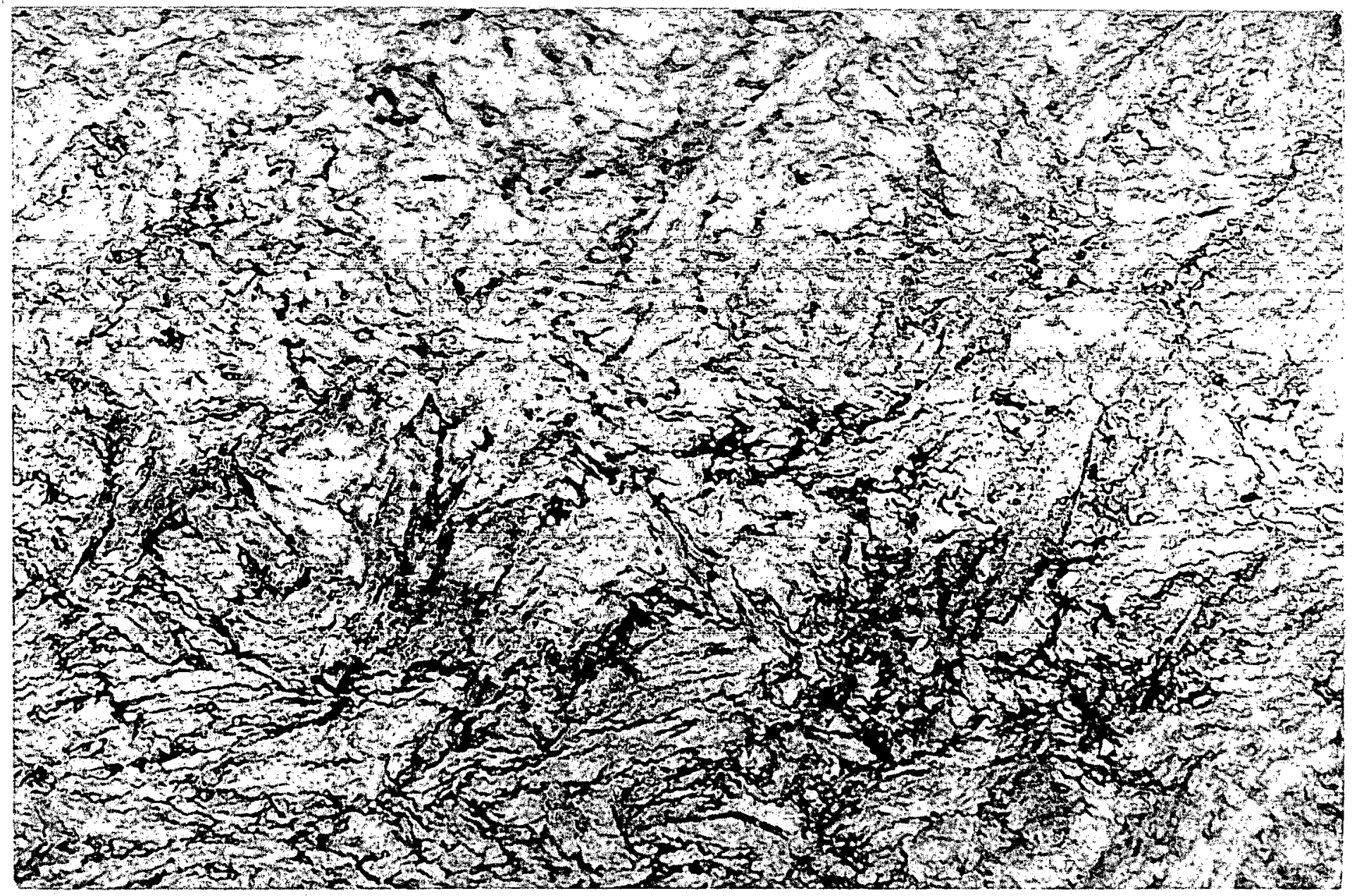

Fig. 42--Photomicrograph of warm-pressed and sintered graphite fuel matrix 
Fission-product control in the HTGR ${ }^{(2)}$ starts in the fuel compacts, where roughly one-half of the fission products formed can be expected to remain fixed, either because they are nonvolatile or because they form stable, nonvolatile carbides. The principal elements of this group are $\mathrm{Y}$, $\mathrm{Zr}, \mathrm{Nb}, \mathrm{Mo}, \mathrm{Tc}, \mathrm{Ru}, \mathrm{Rh}, \mathrm{Pd}, \mathrm{La}, \mathrm{Ce}, \mathrm{Pr}, \mathrm{Nd}$, and $\mathrm{Pm}$. The remaining fission products will diffuse more or less rapidly out of the fuel compact, depending on their volatility, and if not otherwise controlled, they would enter the primary coolant stream. The control method proposed for the HTGR avoids this problem by providing an impervious graphite containment around the fuel compacts, and the interspace between the compacts and the container will be continuously scavenged by a small fraction $(\sim 0.1 \%)$ of the primary coolant flow, which will enter by way of a controlled in-leak. This helium purge stream will carry the fission products to an external fissionproduct trapping system, the purified helium being returned to the primary circuit. The principal advantage of this system over a bypass system is that the chemically reactive or condensable fission products are not allowed to plate out in the primary circuit before reaching the trap. In addition, the trap receives the fission products relatively undiluted, and thus trapping difficulties are decreased.

The fuel compacts should retain or hold up the fission products as long as possible to allow the large energy release of the short half-life fission products to be given up in the element rather than in the trap, where it would result in a cooling problem. Testing of fuel compacts for fissionproduct retention has therefore been an important part of the HTGR fueldevelopment program; these testing techniques and results have been described in previous reports. $(13-16)$

Briefly, the testing method is as follows: Fuel materials (particles, coated particles, or compacts) are subjected to irradiation of shortduration in the General Atomic TRIGA reactor to produce trace levels of fission products. The samples are then placed in a high-temperature graphite-tube 
furnace. Helium flows over the sample and through a system of traps where $\mathrm{Xe}^{133}$ is collected and counted.

In general, a relative method of determining the xenon fraction remaining in the compact, as a function of time, was used. Thus, at the end of a test at a given temperature the compact was brought to a high temperature (usually $2200^{\circ} \mathrm{C}$ ) and all of the xenon activity was driven out. The experimental method was to accumulate the $X e^{133}$ carried from the compact by the helium stream (flow rate approximately $300 \mathrm{~cm}^{3} / \mathrm{min}$ ) on an activated charcoal trap held at liquid-nitrogen temperature. The fraction released at any time was based on the final activity collected.

Zumwalt and Anderson ${ }^{(17)}$ have found that the xenon release from uncoated carbide fuel particles in a typical dispersion fuel element is similar to the krypton release, which fits the equation

$$
\text { Fraction released }=1-\frac{6}{\pi^{2}} \sum \frac{1}{n^{2}} \exp \left(-n^{2} \pi^{2} t / \delta\right),
$$

where

$$
\log \delta(\mathrm{hr})=\frac{16.1 \times 10^{3}}{\mathrm{~T}\left({ }^{\circ} \mathrm{K}\right)}-6.12
$$

This expression has been used to calculate $t_{1 / 2}$ (time to lose $50 \%$ of the xenon) at several temperatures (see Table 9).

Table 9

$\dot{X e}^{133}$ LOSS FROM FUEL COMPACTS

WITH UNCOATED FUEL PARTICLES

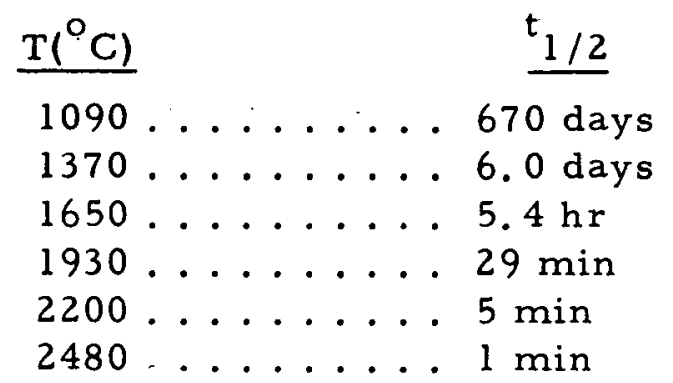


Compacts containing pyrolytic-carbon-coated ( $T h, U) \mathrm{C}_{2}$ particles have shown remarkably improved xenon retention. The initial release curve for an early compact tested at $1700^{\circ} \mathrm{C}$ showed a fast component $\left(1.8 \%\right.$ of $\mathrm{Xe}{ }^{133}$ ) with a characteristic diffusion time of $0.88 \mathrm{hr}$ and a slow component for the balance of the $\mathrm{Xe} \mathrm{e}^{133}$ with a diffusion time of $3.3 \times 10^{4} \mathrm{hr}$. The release at $2200^{\circ} \mathrm{C}$ was characterized by a single component of $2.5 \times 10^{3} \mathrm{hr}$. Furthermore, it proved difficult to get the balance of the xenon activity out of the sample, so a series of thermal-cycling "shock" treatments with a $2600^{\circ} \mathrm{C}$ maximum temperature was performed. Relatively fast release was observed at room temperature following several of the $2600^{\circ} \mathrm{C}$ treatments. It is believed that the severe heating and cooling may have opened up the pyrolytic carbon sheath around the carbide particles. From the slope of the release curves, the characteristic release times $\left(t_{1 / 2}\right)$ at $1700^{\circ}$ and $2200^{\circ} \mathrm{C}$ were estimated to be 35 days and 10 days, respectively.

A xenon-release curve for one of the first compacts prepared with pyrolytic-carbon-coated fuel particles is compared in Fig. 43 with a typical curve for compacts with uncoated particles. Recent tests with pyrolyticcarbon-coated ( $\mathrm{Th}, \mathrm{U}) \mathrm{C}_{2}$ fuel particles that were not in a compact have shown no detectable xenon release during $48 \mathrm{hr}$ at $1700^{\circ} \mathrm{C}$ (upper curve in Fig. 43).

Fission-product-release testing on more highly irradiated fuel compacts is reported below in "Irradiation Studies."

\section{IRRADIATION STUDIES}

The physical characteristics of representative fuel compacts in a radiation field have been studied by means of two types of irradiation capsule: (1) the GA-308 series capsules (see Fig. 44), in which as many as six compacts in tandem may be irradiated simultaneously, and (2) the GA-309 series capsules (see Fig. 45) which are used for the study of the release of gaseous fission products from the fuel compacts during irradiation. The high temperatures produced in the compacts by fission heating are controlled by the variation in thermal conductivity of a binary gas 


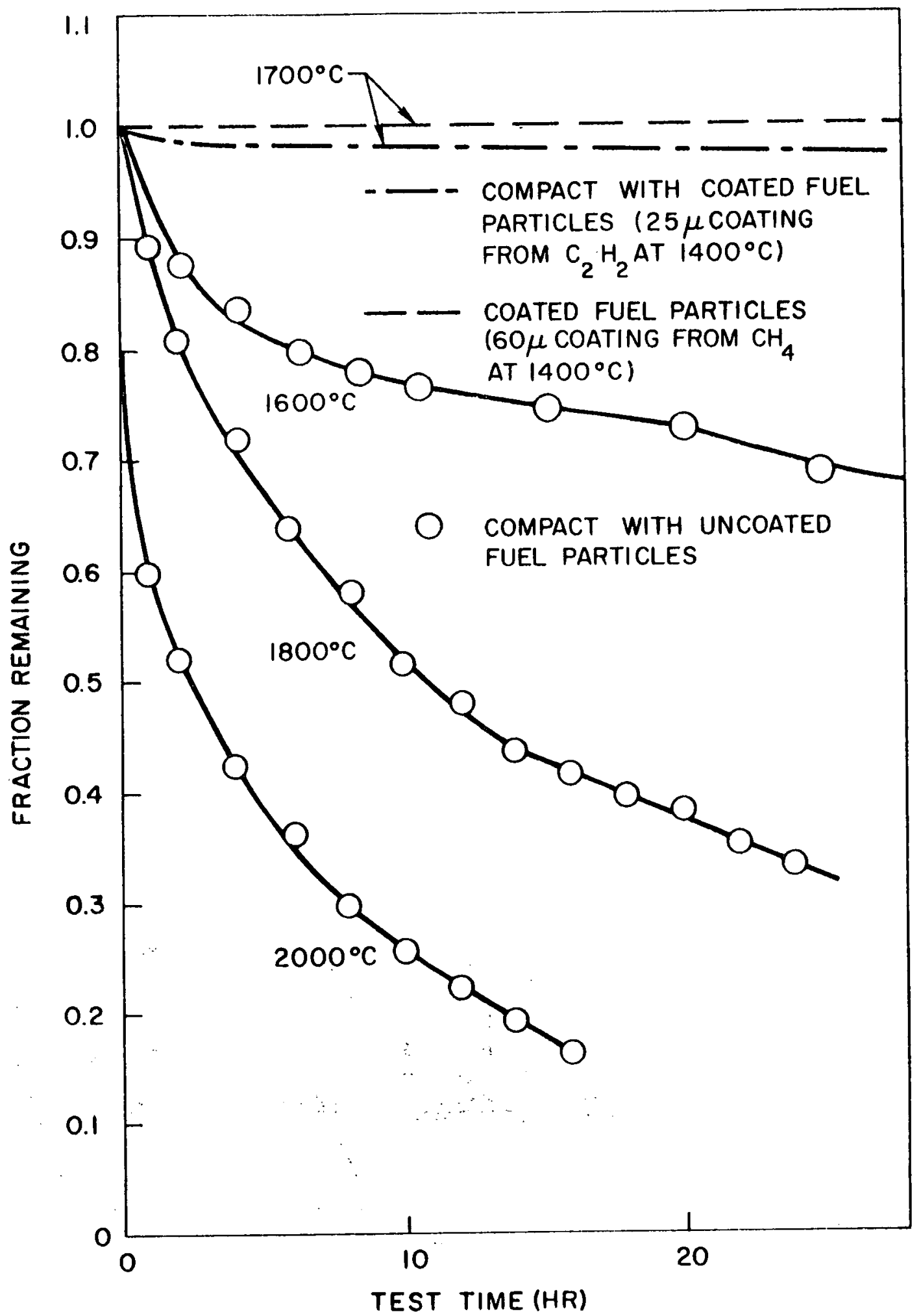

Fig. 43--Release of $\mathrm{Xe}^{133}$ from compacts with coated and uncoated fuel particles at indicated test temperatures 


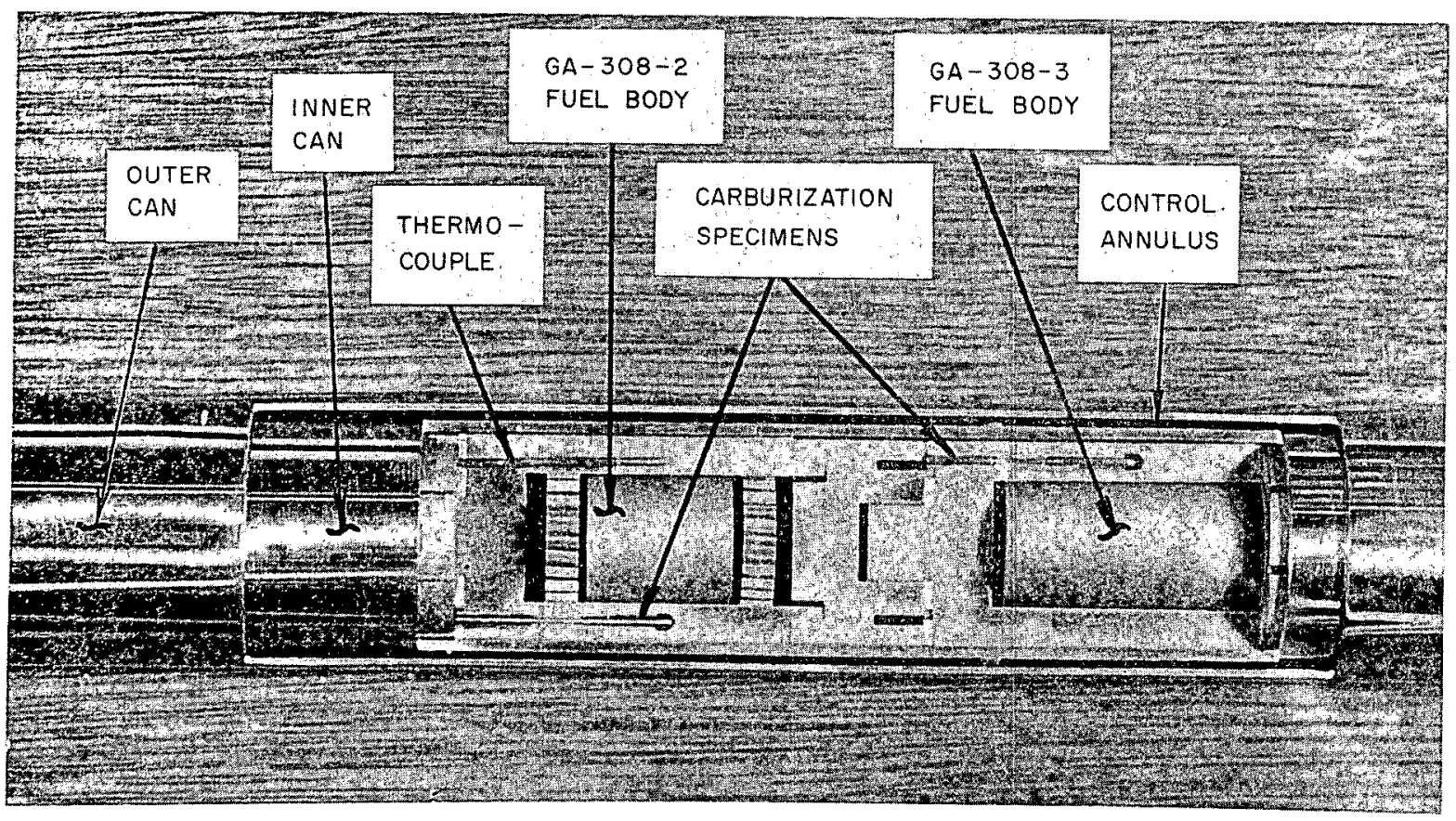

Fig. 44--GA-308 series irradiation capsule

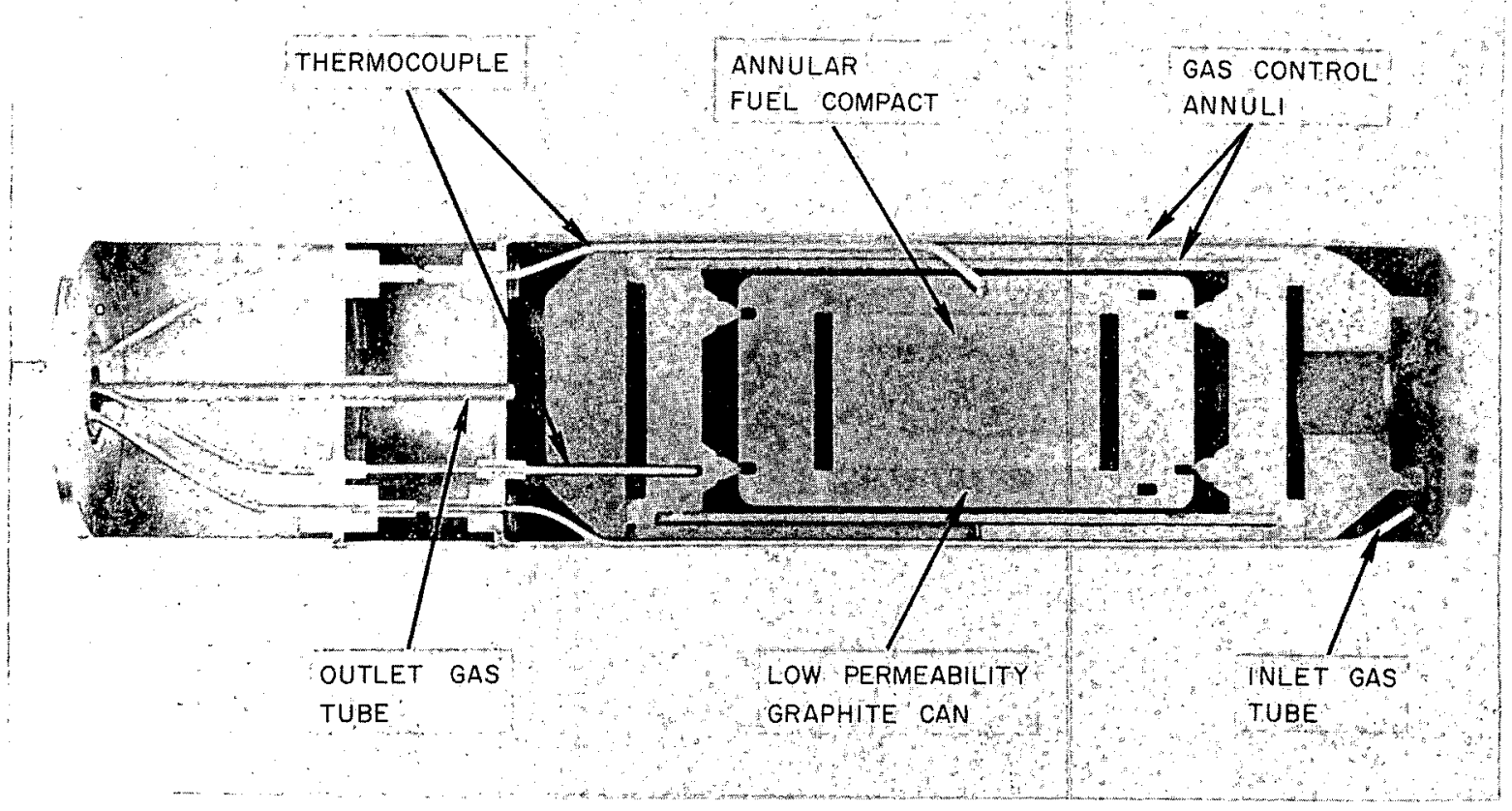

Fig. 45--GA-309 series irradiation capsule 
mixture in a control annulus located between the test specimen and the capsule coolant.

During the irradiation studies described here, the combined fuel $\left(U^{235}\right)$ and fertile $(\mathrm{Th})$ contents of the test compacts were made to correspond to HTGR design loadings. In order to accelerate burnup and obtain high fuel-compact temperatures, additional fuel was substituted for a portion of the thorium, but the carbon-to-metal ( $\mathrm{Th}+\mathrm{U})$ ratio was kept consistent with HTGR design. This seemed to be a safe expedient, since $\mathrm{ThC}_{2}$ and $\mathrm{UC}_{2}$ form a solid-solution system, and substitution of one for the other should lead to no unforeseen difficulties. A burnup equal to $60 \%$ of the HTGR design life of 3 years was obtained in a 4 -month irradiation in the GETR.

The test conditions are listed in Tables 10 and 11 , and the results of several irradiation tests, discussed below, are summarized in Tables 12 through 15. All the fuel compacts were prepared by the warm-press and sinter process previously described.

Table 10

FUEL-COMPACT COMPOSITIONS AND DIMENSIONS FOR GA-308 CAPSULE IRRADIATIONS

\begin{tabular}{l|c|c|c}
\hline & GA-308-2 & GA-308-3 & GA-308-4 \\
\hline Composition & & & \\
Uranium (93\% enriched), wt-\% & 3.1 & 6.5 & 6.0 \\
Thorium, wt-\% & 7.25 & 15.5 & 14.4 \\
Silicon, wt-\% & 10.3 & --- & 1.6 \\
Total metal, wt-\% & 89.7 & 78.0 & 22.0 \\
Graphite, wt-\% & $570: 2.4: 1$ & $240: 2.4: 1$ & $255: 2.4: 1$ \\
C:Th:U, atom ratio & $175: 1$ & 67.1 & $74: 1$ \\
C:Th+U, atom ratio & ---- & ---- & $45: 1$ \\
C:Th+UtSi, atom ratio & & & \\
Dimensions & 1.00 & 1.00 & 1.00 \\
Outside diameter, in. & --- & 0.50 & 0.50 \\
Inside diameter, in. & 1.10 & 1.78 & 1.78 \\
Length, in. &
\end{tabular}


Table 11

BURNUPS AND TEMPERATURES OF IRRADIATIONS FOR GA-308 AND GA-309 CAPSULE IRRADIATIONS

\begin{tabular}{|c|c|c|c|c|}
\hline & $G A-308-2$ & $G A-308-3$ & $G A-308-4$ & $\begin{array}{c}\text { GA-309-4,-5 } \\
\text { and }-6\end{array}$ \\
\hline $\begin{array}{c}\text { Temp. at compact } \\
\text { centerline, }{ }^{\circ} \mathrm{C}\end{array}$ & $1,050-1,200$ & $1,150-1,480$ & $1,090-1,480$ & $1,500-1,900$ \\
\hline $\begin{array}{l}\text { Burnup } \\
\mathrm{U}^{235}, \% \\
\text { Fissions } / \mathrm{cm}^{3} \\
\text { MwD/T } \\
\mathrm{kw}-\mathrm{hr} / \mathrm{cm}^{3}\end{array}$ & $\begin{array}{l}16.7 \\
4.25 \times 10^{19} \\
48,000 \\
21.0\end{array}$ & $\begin{array}{l}18 \\
6.9 \times 10^{19} \\
51,000 \\
600\end{array}$ & $\begin{array}{l}18 \\
6.0 \times 10^{19} \\
51,000 \\
600\end{array}$ & $\begin{array}{l}17 \\
5.4 \times 10^{19} \\
50,000 \\
500\end{array}$ \\
\hline
\end{tabular}

* To May 1, 1961 .

†Design burnup for HTGR is $1.1 \times 10^{20}$ fissions $/ \mathrm{cm}^{3}$.

Irradiation Test of Capsule GA-308-2

The fuel compacts for the irradiation of Capsule GA-308-2 were right circular cylinders 1.00 in. in diameter by 1.10 in. long. Solid-solution ( $T h, U) C_{2}$ fuel particles 110 to $250 \mu$ in diameter were formed by the in situ conversion of $(\mathrm{Th}, \mathrm{U}) \mathrm{O}_{2}$. The fuel content was $3 \mathrm{wt}-\% \mathrm{U}^{235}$; the thorium content was $7 \mathrm{wt}-\%$.

During irradiation, the temperature of the graphite cans containing the fuel compacts varied from $775^{\circ}$ to $830^{\circ} \mathrm{C}$ in the region of highest flux. The fuel-compact temperatures were estimated to be $275^{\circ} \mathrm{C}$ higher than the temperature of the cans. The maximum calculated burnup was $16.7 \%$ of $\mathrm{U}^{235}$, or $48,000 \mathrm{Mw}$-days/ton, which is equivalent to $4.25 \times 10^{19}$ fissions $/ \mathrm{cm}^{3}$.

When the capsule was disassembled, it was noted that the appearance of all the fuel bodies was excellent (see Fig. 46). The dimensional measurements of the fuel bodies, which checked against the preirradiation values, are given in Table 12 . 

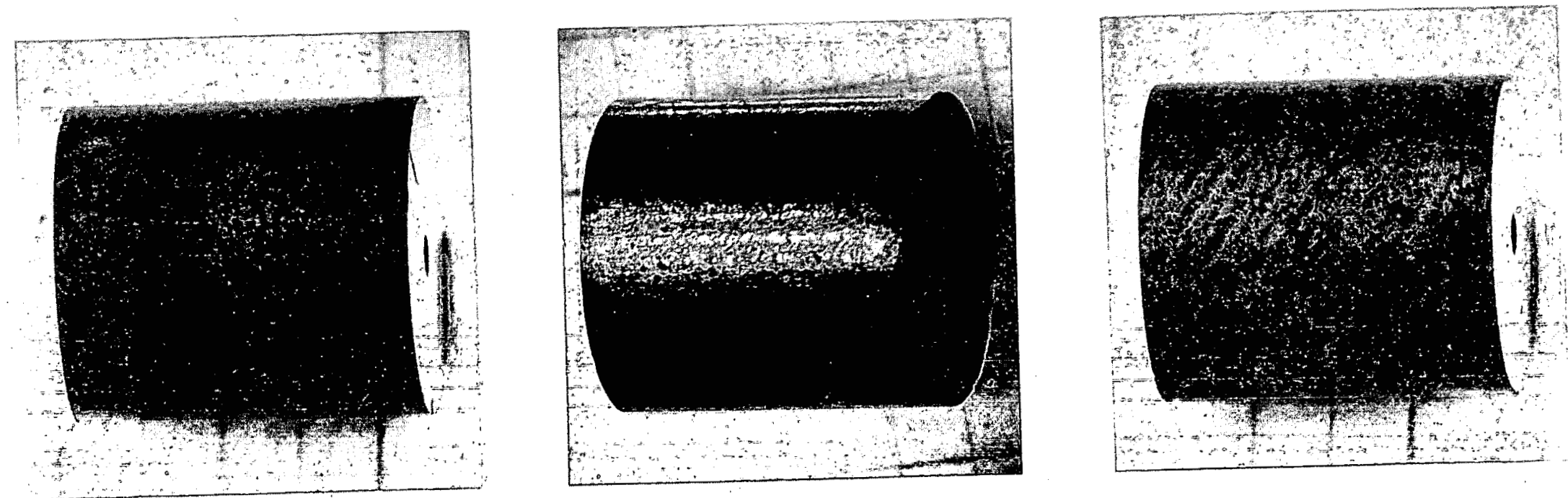

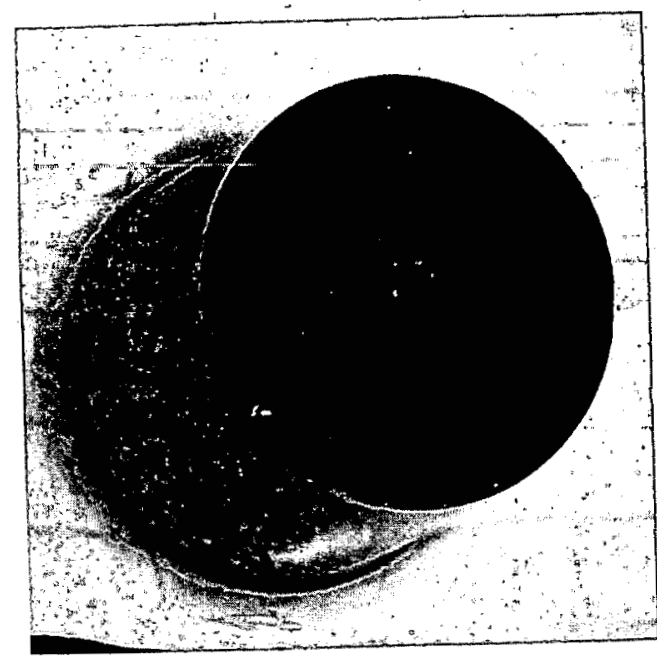

Compact No. 4

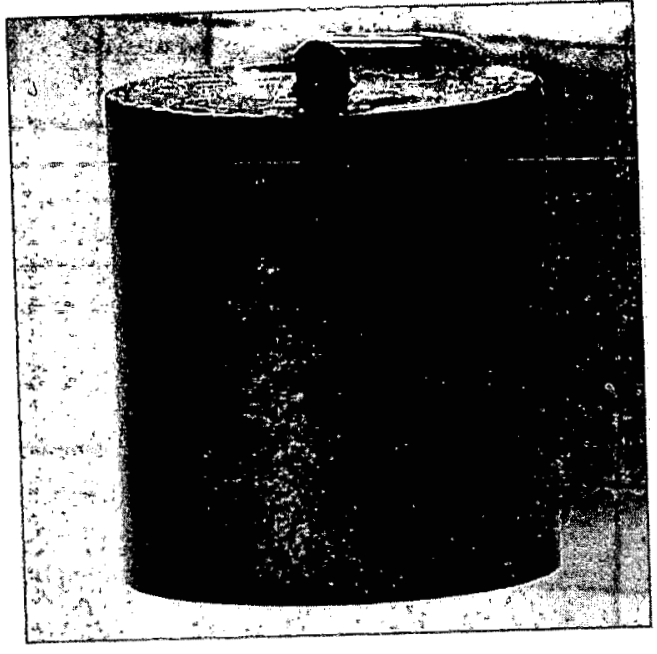

Compact No. 5

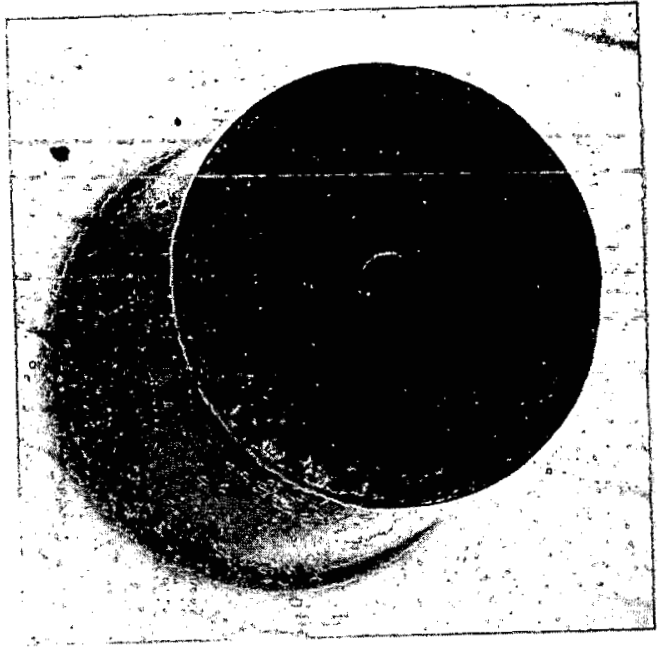

Compact No. 6

Fig. 46--Compacts from capsule GA-308-2 afterirradiation to $4.25 \times 1019$ fissions $/ \mathrm{cm}^{3}$ at $1050^{\circ}$ to $1200^{\circ} \mathrm{C}$ 
Table 12

DIMENSIONAL CHANGES OF FUEL COMPACTS

FROM IRRADIATION OF CAPSULE GA-308-2

\begin{tabular}{c|c|c|c|c}
\hline Compact & $\begin{array}{c}\text { Av. Temp. of } \\
\text { Graphite Can } \\
\left({ }^{\circ} \mathrm{C}\right)\end{array}$ & $\begin{array}{c}\text { Fuel -body } \\
\text { Centerline Temp. } \\
\text { Calc. }\left({ }^{\circ} \mathrm{C}\right)\end{array}$ & $\begin{array}{r}\text { Dimensional Changes } \\
(\%)\end{array}$ \\
\hline 4 & 820 & 1200 & $\Delta \mathrm{D}$ & $\Delta \mathrm{L}$ \\
\hline 5 & 830 & 1200 & -0.2 & 0 \\
6 & 775 & 1050 & -0.1 & -0.1 \\
\hline
\end{tabular}

Irradiation Test of Capsule GA-308-3

The fuel compacts in the irradiation test of Capsule GA-308-3 differed in three major respects from those tested in the previous irradiation. First, these compacts were of an annular design (in order to correspond more closely to the configuration of the H.TGR compact); second, the metal (Th $+U$ ) loading was increased from 10 to $22 \mathrm{wt}-\%(6.5 \% \mathrm{U}, 15.5 \% \mathrm{Th})$, corresponding to the increased fuel concentration in the HTGR occasioned by the change to annular fuel compacts; third, three different particle sizes of fuel material were used to permit comparison of radiation effects as a function of fuelparticle size. The sizes of the particles were $<50 \mu, 110$ to $250 \mu$, and 250 to $500 \mu$. Six compacts were tested, two with each size of fuel particle. The compacts were made from solid-solution ( $\mathrm{Th}, \mathrm{U}) \mathrm{O}_{2}$ particles that were converted in situ to $(\mathrm{Th}, \mathrm{U}) \mathrm{C}_{2}$ during compact fabrication. Each compact was $1.00 \mathrm{in.}$ in outside diameter, $0.50 \mathrm{in}$. in inside diameter, and $1.75 \mathrm{in}$. long, and a graphite rod was inserted in the center of each compact to simulate the unfueled region in the HTGR fuel compact.

During irradiation, the temperature of the compacts ranged from $650^{\circ}$ to $925^{\circ} \mathrm{C}$; the burnup reached was $18 \%$ of the $\mathrm{U}^{235}, 6.9 \times 10^{19}$ fission $/ \mathrm{cm}^{3}$, or $600 \mathrm{kw}-\mathrm{hr} / \mathrm{cm}^{3}$. The dimensional changes and other pertinent data are recorded in Table, 13.

The postirradiation appearance of the six fuel bodies was good. A typical fuel compact before irradiation is shown in Fig. 47, and Fig. 48 


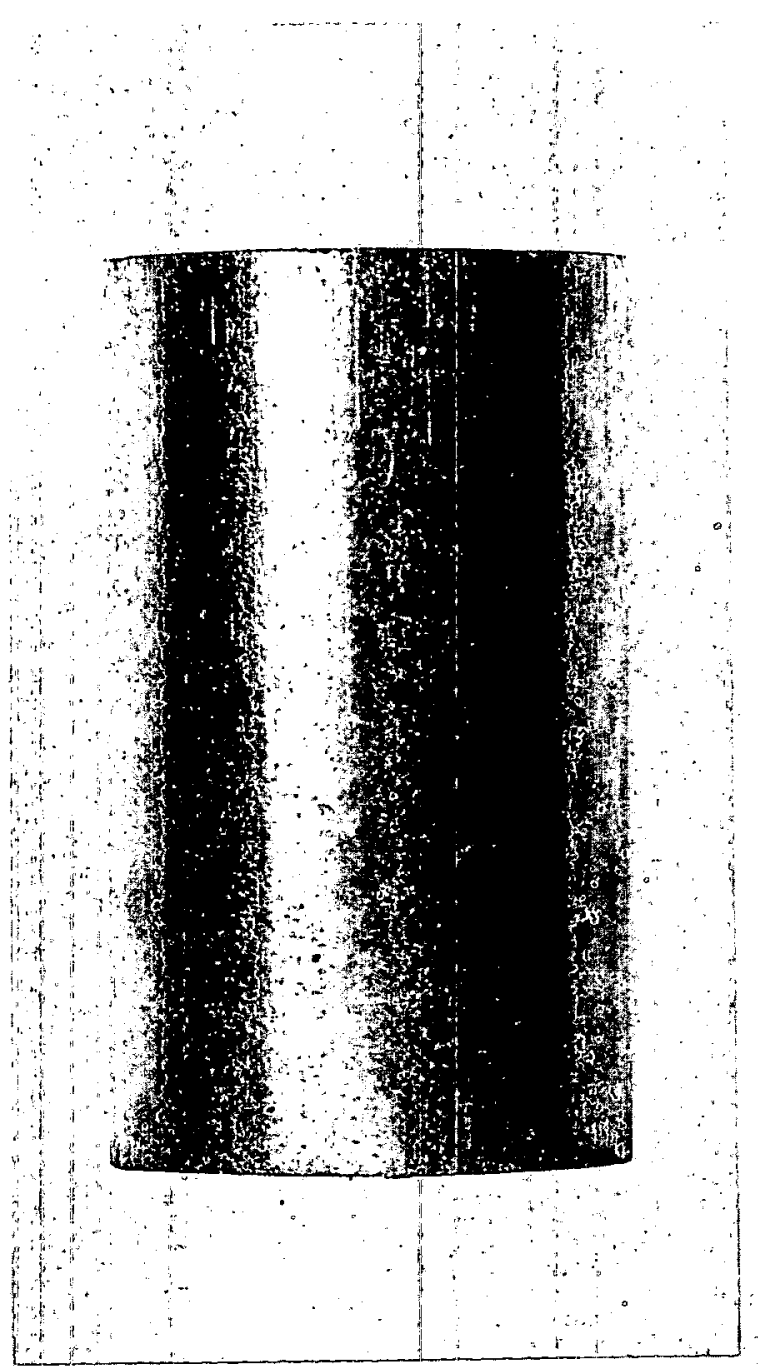

Fig: 47--Fuel compact of the type prepared for the irradiation of capsule GA-308-3 


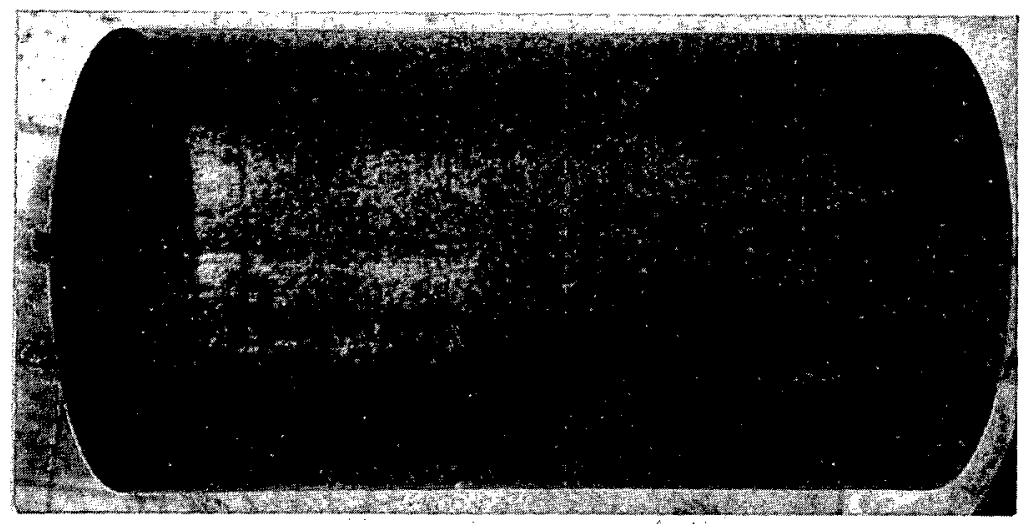

Compact No. 3; fuel particles $<50 \mu$

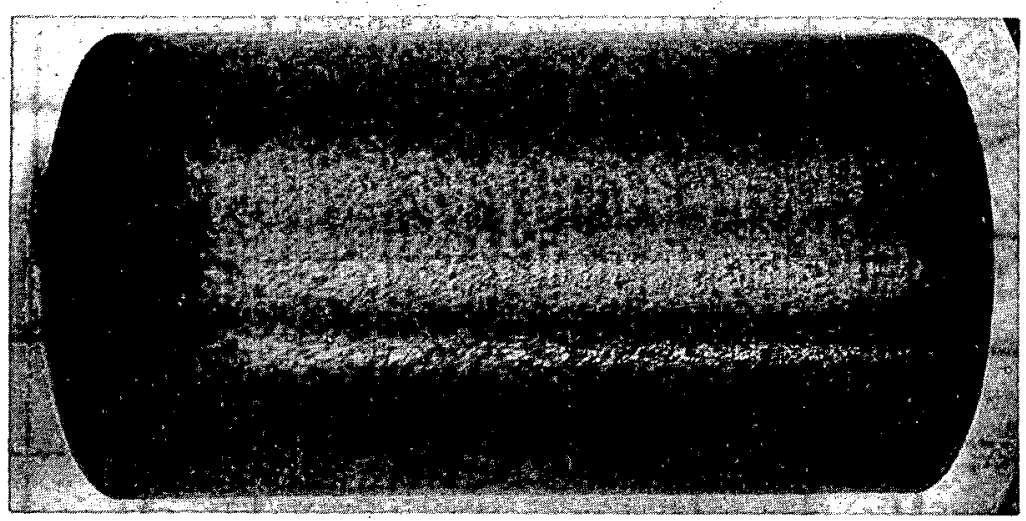

Compact No. 2; fuel particles 110-250 $\mu$

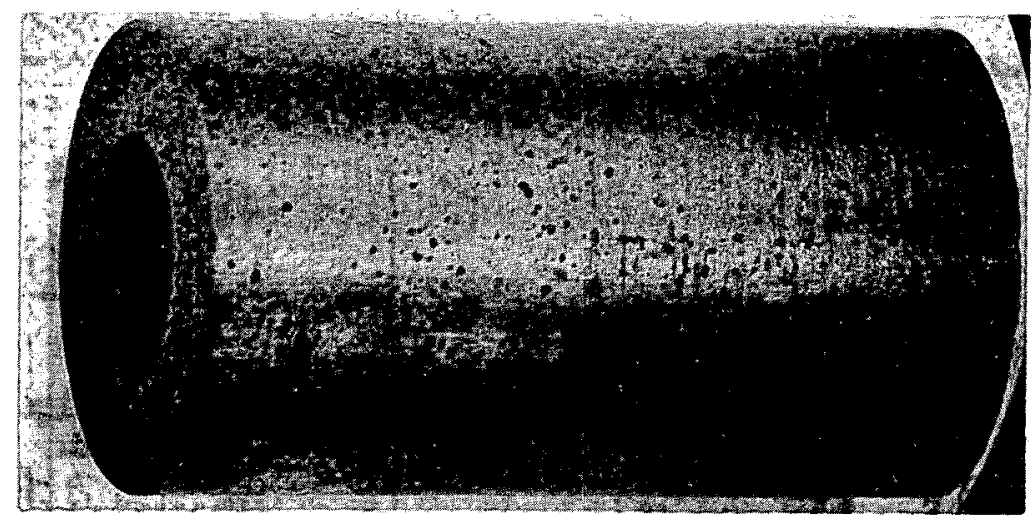

Compact No. 6; fuel particles 250-500 $\mu$

Fig. 48--Fuel compacts from capsule GA-308-3 after irradiation to $6.9 \times 10^{19}$ fissions $/ \mathrm{cm}^{3}$ at $1150^{\circ}$ to $1480^{\circ} \mathrm{C}$; surface pips are due to partial hydrolysis of carbide fuel during hotcell examination 
Table 13

\section{DIMENSIONAL CHANGES OF FUEL COMPACTS}

FROM IRRADIATION OF CAPSULE GA-308-3

\begin{tabular}{c|c|c|c|c|c}
\hline & $\begin{array}{c}\text { Fuel- } \\
\text { particle } \\
\text { Size } \\
(\mu)\end{array}$ & $\begin{array}{c}\text { Av. Temp. of } \\
\text { Graphite Can } \\
\left({ }^{\circ} \mathrm{C}\right)\end{array}$ & $\begin{array}{c}\text { Fuel-body } \\
\text { Centerline Temp. } \\
\text { Calc. }\left({ }^{\circ} \mathrm{C}\right)\end{array}$ & \multicolumn{2}{|c}{$\begin{array}{c}\text { Dimensional Changes } \\
(\%)\end{array}$} \\
\cline { 4 - 6 } & $250-500$ & $650-760$ & 1200 & $\Delta \mathrm{D}$ & $\Delta \mathrm{L}$ \\
2 & $110-250$ & $730-840$ & 1300 & -0.2 & +0.2 \\
3 & $<50$ & $840-900$ & 1400 & -1.7 & +2.2 \\
4 & $<50$ & $900-925$ & 1480 & -2.2 & +3.0 \\
5 & $110-250$ & $760-840$ & 1200 & -0.3 & $<-0.1$ \\
6 & $250-500$ & $700-790$ & 1150 & 0 & $<+0.1$ \\
\hline
\end{tabular}

shows the irradiated compacts. (The speckled surfaces on the irradiated compacts are a result of partial hydrolysis of the particles near the surface of the compact due to exposure to air during hot-cell examination.) After irradiation the compacts had approximately the same appearance as before irradiation; no spalling or cracking was evident on any of the six compacts in this capsule.

It will be noted that while the diametral change in these compacts was one of contraction, the longitudinal dimension of the bodies increased. Furthermore, the largest variations occurred in compacts with fuel particles smaller than $50 \mu$. These changes are characteristic of neutron radiation effects on unfueled graphite. However, the effect of small fuel particles is much larger than would be expected for pile-grade graphite under equivalent neutron exposure. This indicates a contribution from fission recoils, as one would expect. The smallest particle size that will produce acceptable dimensional stability in the fuel bodies lies apparently somewhere between 50 and $100 \mu$.

Irradiation Test of Capsule GA-308-4

The fuel compacts for the irradiation of Capsule GA-308-4 differed in one respect from the GA-308-3 compacts; they were prepared from thorium- 
uranium silicide $(7.4 \mathrm{wt}-\% \mathrm{Si}$ ) fuel rather than thorium-uranium oxide.

The thorium and uranium were converted to dicarbides and the silicon to $\mathrm{SiC}$ in situ during fuel-compact fabrication. Dimensions, fuel loadings, and fuel-particle size were the same as for the GA-308-3 test.

During irradiation, the centerline temperatures of these compacts ranged from $1090^{\circ}$ to $1480^{\circ} \mathrm{C}$, as determined by melt wires placed in the graphite core of each compact. Burnup was $6.0 \times 10^{19}$ fissions $/ \mathrm{cm}^{3}, 18 \%$ of the $\mathrm{U}^{235}$, or $51,000 \mathrm{kw}-\mathrm{hr} / \mathrm{cm}^{3}$. Dimensional changes are summarized in Table 14.

Table 14

DIMENSIONAL CHANGES OF FUEL COMPACTS FROM IRRADIATION OF CAPSULE GA-308-4

\begin{tabular}{c|c|c|c|c|c}
\hline & $\begin{array}{c}\text { Fuel- } \\
\text { particle } \\
\text { Size } \\
(\mu)\end{array}$ & $\begin{array}{c}\text { Av. Temp. of } \\
\text { Graphite Can } \\
\left({ }^{\circ} \mathrm{C}\right)\end{array}$ & $\begin{array}{c}\text { Fuel-body } \\
\text { Centerline Temp. } \\
\text { Calc. }\left({ }^{\circ} \mathrm{C}\right)\end{array}$ & \multicolumn{2}{|c}{$\begin{array}{c}\text { Dimensional Changes } \\
(\%)\end{array}$} \\
\hline 1 & $<50$ & $650-760$ & $1090^{*}$ & -0.9 & +3.0 \\
2 & $250-500$ & $700-790$ & 1290 & 0 & +0.3 \\
3 & $<50$ & $790-870$ & 1370 & -0.8 & +0.8 \\
4 & $110-250$ & $870-925$ & $1480 \dagger$ & -0.1 & $<+0.1$ \\
5 & $250-500$ & $790-840$ & 1230 & 0 & +0.1 \\
6 & $110-250$ & $730-815$ & 1175 & 0 & +0.1 \\
\hline
\end{tabular}

The appearance of these bodies was good, although surface roughening was noted on one fuel body. The exact cause of this condition is not known. The general appearance of the fuel compacts before irradiation was similar to that shown in Fig. 47. Except for the surface roughening of compact No. 3 and a crack in compact No. 5, the condition of the remaining compacts (see Fig. 49) in this capsule is comparable to that before irradiation.

The dimensional changes, again, indicate the importance of particle 


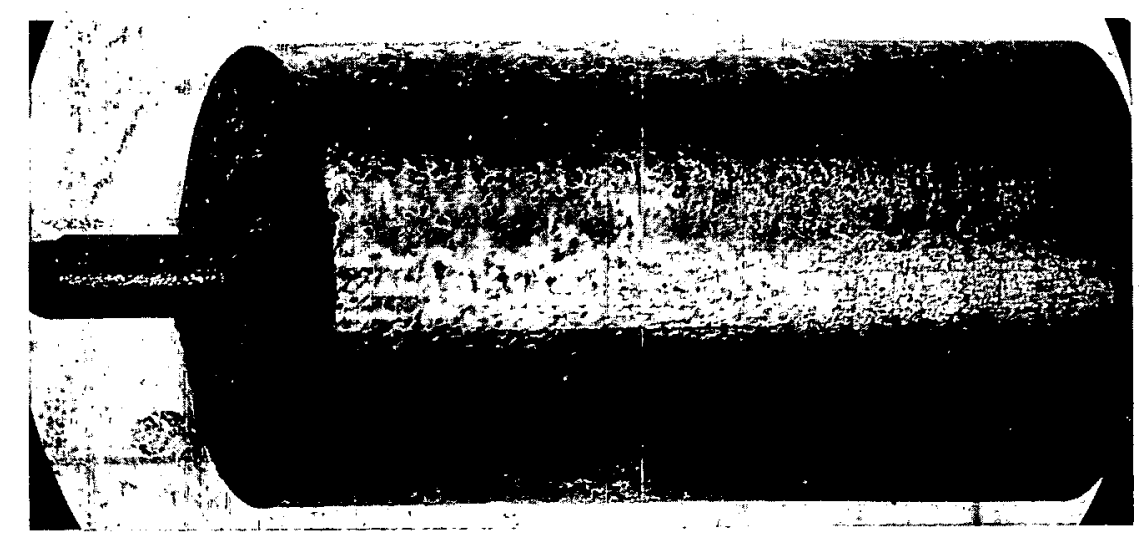

Compact No. 1; fuel particles $<50 \mu$

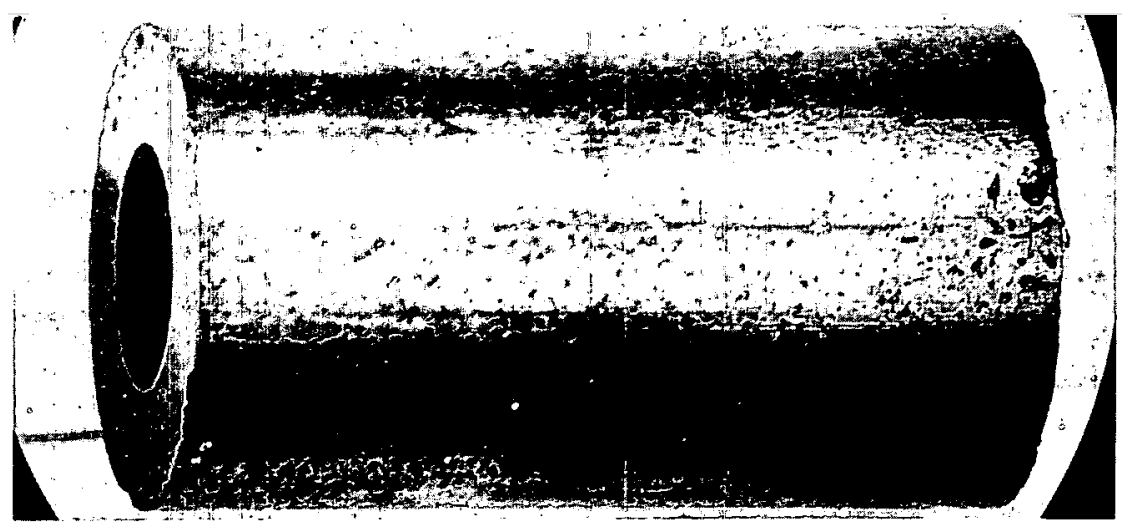

Compact No. 6; fuel particles $110-250 \mu$

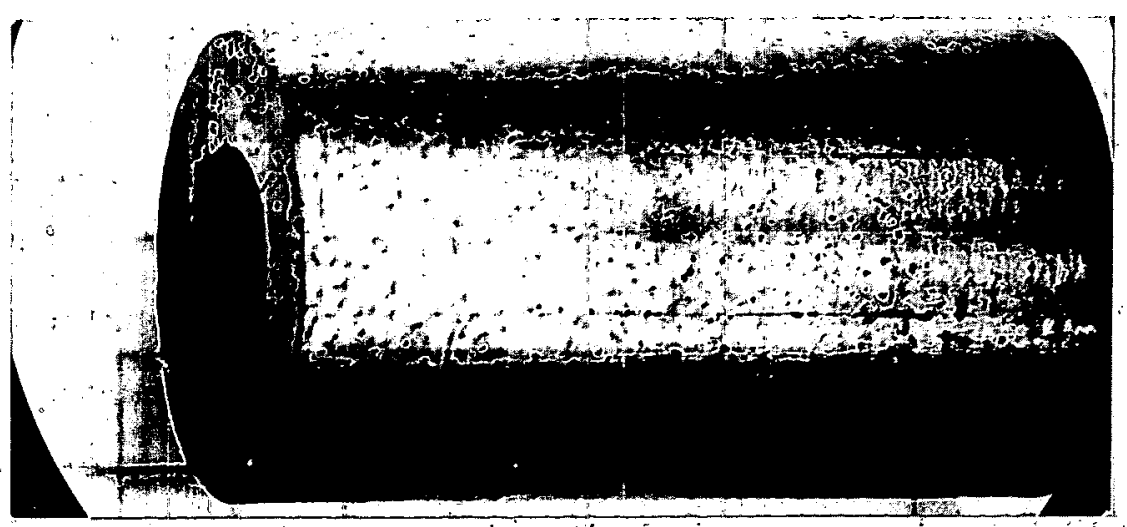

Compact No. 2; fuel particles $250-500 \mu$

Fig. 49--Fuel compacts from capsule GA-308-4 after irradiation to $6 \times 10^{19}$ fissions $/ \mathrm{cm}^{3}$ at $1090^{\circ}$ to $1480^{\circ} \mathrm{C}$; surface pips are due to partial hydrolysis of carbide fuel during hot-cell examination 
size. In this capsule one of the fuel bodies containing small particles was placed in a cold region and another in a hot region. In both cases there was a maximum contraction, indicating that the fission-recoil effect is rather insensitive in this temperature range.

The data obtained from these capsule irradiations indicate that, in general, these graphite matrix compacts are acceptable from the point of view of dimensional stability and physical integ rity at metal loadings up to 22 wt $-\%$. The dimensional stability can be affected by fuel-particle size, although it seems to be somewhat insensitive to temperature. The burnups for these capsules are $60 \%$ of that expected for the HTGR fuel. The starting material, whether oxide or silicide, performed satisfactorily.

Irradiation Test of Capsule GA-309

The irradiation test of Capsule GA-309 was designed to measure the in-pile, steady-state release of fission products from fuel compacts at elevated temperatures. In this experiment, three capsules of the type shown in Fig. 45 are irradiated in the same test hole in the reactor. From time to time the capsules are purged with helium; the released fission-product gases are then allowed to accumulate for $24 \mathrm{hr}$ and the capsule is again purged with helium. This last purge is sampled, aliquoted, and analyzed using gamma-spectrometric techniques. The disintegration rates of the fission-product nuclides $\mathrm{Xe}^{138}, \mathrm{Kr}^{87}, \mathrm{Kr}^{85 \mathrm{~m}}, \mathrm{Xe}^{135}, \mathrm{Xe}^{133}$, and $\mathrm{Kr}^{85}$ at sampling time are determined by using their known decay schemes and half lives and the known gamma-counting efficiency of the scintillation detector of the spectrometer. Fission rates for the fuel specimens are calculated from their known $U^{235}$ content, from the reactor power, and from flux as a function of reactor power and control-rod-bank setting at the position of the given capsule. The fractional steady-state release of nuclide $i\left(F_{i}\right)$ is given by

$$
F_{i}=\frac{R_{i} / y_{i}\left(1-e^{-\lambda_{i} t}\right)}{R_{f}},
$$

* See Ref. 16, p. 154. 
where $R_{f}=$ corrected fission rate $(f / s)$, $\begin{aligned} R_{i}= & \text { disintegration rates of nuclide } i \text { at sampling time in entire purge } \\ & \text { sample }(d / s),\end{aligned}$

$\lambda_{i}=$ decay constant for $i$,

$y_{i}=$ fractional fission yield of $i$,

$t=$ accumulation time (usually about $24 \mathrm{hr}$ ).

Graphite compacts containing pyrolytic-carbon-coated (Th, U) $\mathrm{C}_{2}$ particles were used for the GA-309-4, -5 , and -6 group of irradiations. Since each capsule was designed for the same power generation $(4500 \mathrm{w})$, the fuel loadings were different for each compact to compensate for the axial-flux distribution in the reactor. Table 15 gives the fuel loadings and dimensions of these compacts.

Table 15

FUEL LOADINGS AND COMPACT DIMENSIONS FOR CAPSULES GA-309-4, -5 , AND -6

\begin{tabular}{l|c|c|c}
\hline & GA-309-4 & GA-309-5 & GA-309-6 \\
\hline $\begin{array}{l}\text { Composition } \\
\text { Uranium (93\% enriched), }\end{array}$ & & & \\
wt-\% & 7.6 & 5.5 & 6.7 \\
Thorium, wt-\% & 17.4 & 12.5 & 15.3 \\
Total metal, wt-\% & 25.0 & 18.0 & 22.0 \\
Graphite, wt-\% & 75.0 & 82.0 & 78.0 \\
C:Th:U, atom ratio & $194: 2.3: 1$ & $292: 2.3: 1$ & $228: 2.3: 1$ \\
C:metal, atom ratio & $59: 1$ & $88: 1$ & $69: 1$ \\
Dimensions : & & & \\
Outside diameter, in. & 1.00 & 1.00 & 1.00 \\
Inside diameter, in. & 0.50 & 0.50 & 0.50 \\
Length, in. & 1.78 & 1.78 & 1.78 \\
\hline
\end{tabular}

The coated carbide fuel used for these compacts was some of the first material produced, and particle densities: we re low and coatings thin (Fig. 50). The size of the carbide particles was 105 to $250 \mu$, and the pyrolytic-carbon coating was $30 \mu$ thick. The fuel compacts (Fig. 51), which 


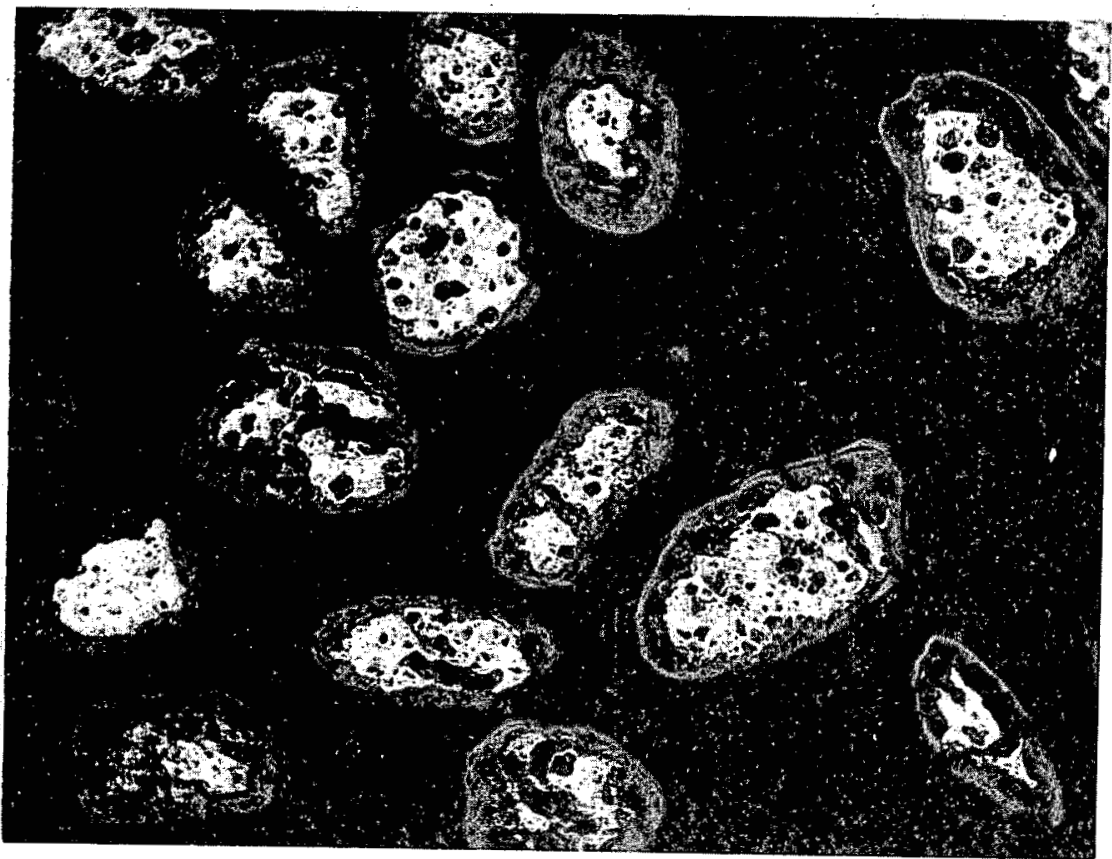

$(75 \times)$

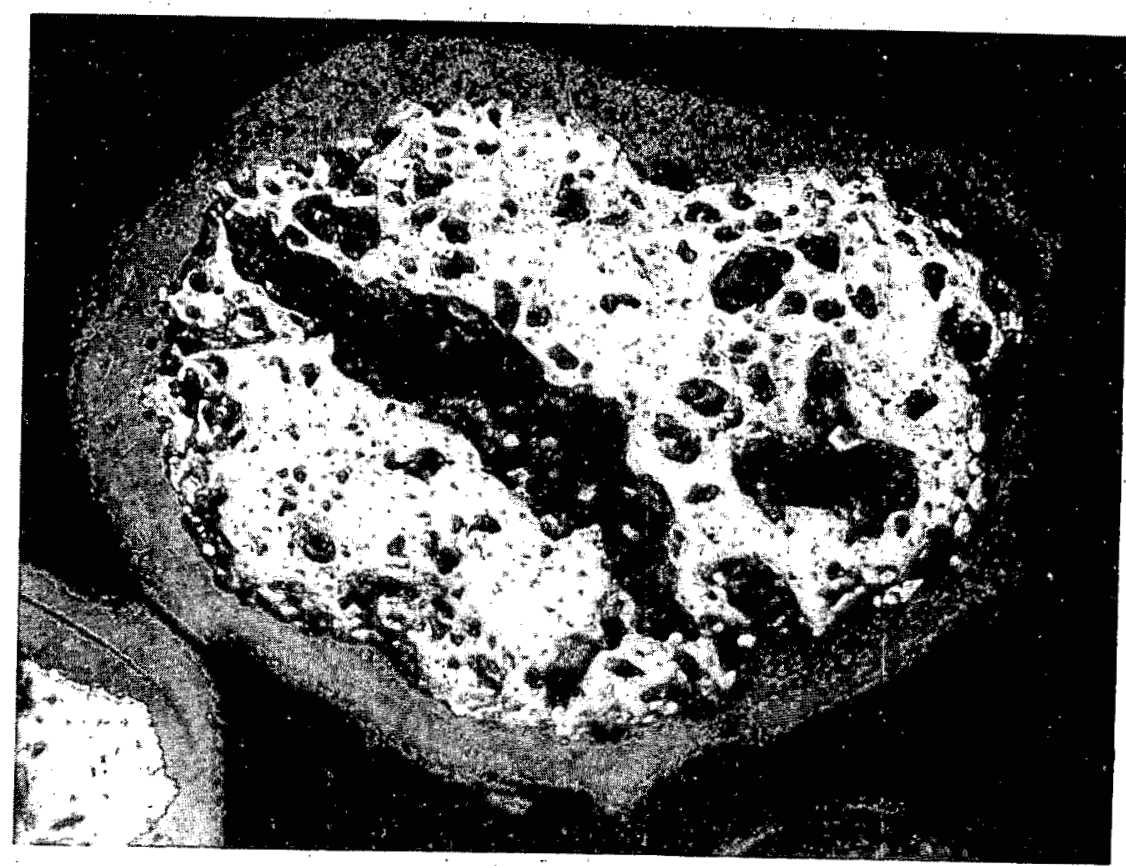

$(250 \times)$

Fig. 50--Pyrolytic-carbon-coated ( Th, U)C fuel particles prepared for GA-309-4, -5 , and -6 capsule irradiations; coatings deposited from acetylene at $1400^{\circ} \mathrm{C}$ 

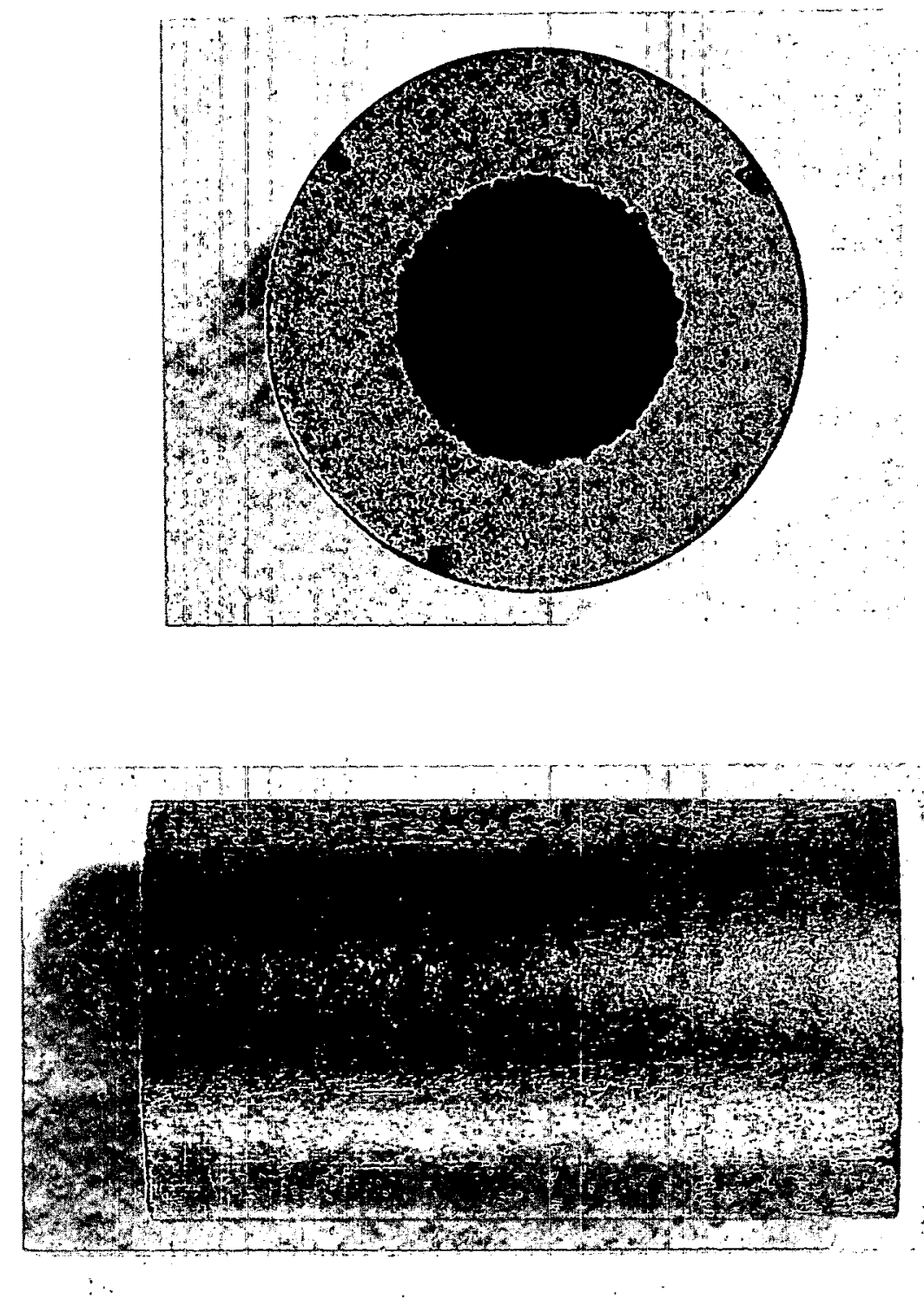

Fig. 51--Fuel compacts containing pyrolytic-carboncoated ( $\mathrm{Th}, \mathrm{U}) \mathrm{C}_{2}$ fuel particles typical of those prepared for the GA-309-4, -5 , and -6 and GA-309-7, -8 ; and -9 capsule irradiations 
were annular and were of the same dimensions as the GA-308-3 and -4 compacts, were produced by the warm-press and sinter process.

The GA-309-4, -5 , and -6 purge capsules began operating in the GETR in November, 1960, and by the end of April, 1961, they had achieved about $50 \%$ of the HTGR burnup. Tables 16,17 , and 18 give the percentage of steady-state release $\left(F_{i} \times 100\right)$ of the xenon and krypton isotopes as determined at various times since startup. The total number of megawattdays of reactor power logged as irradiation time up to the time of sampling is listed along with the date of removal from the reactor and the estimated fuel-body temperature at the time the sample was accumulated.

The data show an indication of increasing $F_{i}$ with increasing fuel-body temperature; also, $F_{i}$ shows some tendency to increase with increasing megawatt-days (MwD) of exposure in the reactor. The results indicate that the pyrolytic-carbon-coated fuel particles were largely intact and had a long characteristic diffusion time, $\gg 5$ days. However, it appears that $1 \%$ to $3 \%$ of the particles in the GA-309-5 and GA-309-6 fuel compacts $(<1 \%$ in the case of GA-309-4) were broken open and showed a steady-state krypton and xenon release behavior something like that of uncoated carbide particles. Sample series 23, 24, and 25 represent the first of a number of tests designed to determine the variation of $\mathrm{F}_{i}$ with fuel-compact temperature.

Capsules GA-309-7, -8 , and -9 have been prepared and irradiation testing was begun in May, 1961. Two of these capsules contain compacts made with denser fuel particles with thick (50 to $60 \mu$ ) pyrolytic-carbon coatings (see Figs. 52 and 53). The third capsule contains the same fuel particles but with thin (10 to $15 \mu$ ) coatings (Fig. 54) to simulate possible end-of-life conditions.

High-burnup Irradiation Test of Capsule GA-113

In order to investigate end-of-life fission-gas pressure conditions inside coated fuel particles, compacts containing a small number of coated particles, of the type used for the irradiation test of capsules GA-309-4, 
Table 16

KRYPTON AND XENON RELEASE DATA FOR CAPSULE GA-309-4

\begin{tabular}{|c|c|c|c|c|c|c|c|c|c|c|}
\hline \multirow[b]{2}{*}{$\begin{array}{l}\text { Sample } \\
\text { Series }\end{array}$} & \multirow[b]{2}{*}{$\begin{array}{c}\text { Date Removed } \\
\text { From GETR }\end{array}$} & \multirow[b]{2}{*}{$\begin{array}{c}\text { Irradiation } \\
\text { Time } \\
(M w D)\end{array}$} & \multirow[b]{2}{*}{$\begin{array}{c}\text { Fuel-compact } \\
\text { remp. } \\
\left({ }^{n} \mathrm{C}\right)\end{array}$} & \multicolumn{7}{|c|}{ Steady-state Release $\left(7_{0}\right)$} \\
\hline & & & & $\begin{array}{l}X e^{138} \\
(17 \mathrm{~m})\end{array}$ & $\begin{array}{c}\mathrm{Kr}^{87} \\
(78 \mathrm{~m})\end{array}$ & $\begin{array}{l}\mathrm{Kr}^{8 \mathrm{R}} \\
(2.8 \mathrm{~h})\end{array}$ & $\begin{array}{l}\mathrm{Kr} \mathrm{r}^{85 \mathrm{~m}} \\
(4.4 \mathrm{~h})\end{array}$ & $\begin{array}{l}\mathrm{Xe}^{135} \\
(9.1 \mathrm{~h})\end{array}$ & \begin{tabular}{|l}
$X \mathrm{e}^{133}$ \\
$(5.3 \mathrm{~d})$
\end{tabular} & $\begin{array}{c}\mathrm{Kr}^{85} \\
(10.3 \mathrm{y})\end{array}$ \\
\hline 8 & $11 / 22 / 60$ & $19 !$ & 960 & $\ldots$ & 0.002 & 0.004 & 0.006 & 0.0011 & 0.017 & 0.29 \\
\hline 11 & $12 / 9 / 60$ & 518 & 1650 & 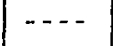 & 0.09 & 0.07 & 0.30 & 0.005 & 0.041 & 2.1 \\
\hline $12 \mathrm{~A}$ & $1 / 12 / 60$ & 764 & 1471 & $-\cdots$ & 0.13 & 0.15 & 0.23 & 0.015 & 0.12 & --- \\
\hline 14 & $1 / 18 / 61$ & 944 & 1588 & $\leq 0.06$ & $0.10^{\circ}$ & 0.19 & 0.26 & 0.028 & 0.28 & 2.4 \\
\hline 17 & $1 / 25 / 61$ & 1111 & 1427 & 0.027 & 0.057 & 0.094 & 0.12 & 0.009 & 0.078 & $-\cdots$ \\
\hline 20 & $2 / 1 / 61$ & 1321 & 1535 & --- & 0.09 & 0.15 & 0.23 & 0.014 & 0.20 & 1.9 \\
\hline 2.3 & $3 / 23 / 61$ & 1495 & $\ldots$ & $\ldots$ & 0.13 & 0.10 & 0.20 & 0.015 & 0.028 & $\ldots$ \\
\hline
\end{tabular}

* $1400 \mathrm{MwD}$ is equivalent to $\sim 9 \% \mathrm{U}^{235}$ burnup, or $26,000 \mathrm{MwD} / \mathrm{T}$, or $280 \mathrm{kw}-\mathrm{hr} / \mathrm{cm}^{3}$

Table 17

KRYPTON AND XENON RELEASE DATA FOR CAPSULE GA-309-5

\begin{tabular}{|c|c|c|c|c|c|c|c|c|c|c|}
\hline \multirow[b]{2}{*}{$\begin{array}{l}\text { Sample } \\
\text { Series }\end{array}$} & \multirow[b]{2}{*}{$\begin{array}{c}\text { Date Removed } \\
\text { From GETR }\end{array}$} & \multirow[b]{2}{*}{$\begin{array}{c}\text { Irradiation } \\
\text { T'ime } \\
\text { (MwD) }\end{array}$} & \multirow[b]{2}{*}{$\begin{array}{c}\text { Fuel-compart } \\
\text { lemp. } \\
\text { (' } \mathrm{C})\end{array}$} & \multicolumn{7}{|c|}{ Steady-state Release $(\%)$} \\
\hline & & & & $\begin{array}{l}x e^{138} \\
(17 m)\end{array}$ & $\begin{array}{l}\mathrm{Kr}^{87} \\
(78 \mathrm{~m})\end{array}$ & $\begin{array}{l}\mathrm{Kr}^{88} \\
(2.8 \mathrm{~h})\end{array}$ & $\begin{array}{l}\mathrm{Kr} \\
(4.4 \mathrm{~h})\end{array}$ & $\begin{array}{l}X e^{I 35} \\
(9.1 h)\end{array}$ & $\begin{array}{l}\mathrm{Xe}^{133} \\
(5.3 d)\end{array}$ & $\begin{array}{c}\mathrm{Kr}^{85} \\
(10,3 \mathrm{y})\end{array}$ \\
\hline 8 & $11 / 22 / 60$ & 191 & 1524 & $-\cdots$ & 0.11 & 0.19 & 0.35 & 0.028 & 0.14 & 1.0 \\
\hline 10 & $12 / 8 / 60$ & 494 & 1702 & & 0.39 & 0.65 & 0.94 & 0.0049 & 0.78 & 7.2 \\
\hline 13 & $1 / 13 / 61$ & 794 & 1760 & $-\cdots$ & 0.37 & 0.49 & 0.76 & 0.047 & 0.53 & -- \\
\hline 15 & $1 / 19 / 61$ & 974 & 1799 & - & 0.79 & 0.62 & 0.92 & 0.072 & 0.79 & -.. \\
\hline 18 & $1 / 26 / 61$ & 1141 & 1904 & 0.68 & 0.56 & 0.58 & 0.80 & 0.073 & 1.17 & 25 \\
\hline 21 & $2 / 2 / 61$ & 1351 & 1751 & --- & 0.11 & 0.19 & 0.36 & 0.016 & 0.27 & 5.4 \\
\hline 24 & $3 / 24 / 61$ & 1525 & - . - & $\ldots$ & 0.27 & 0.31 & 0.70 & 0.027 & 0.18 & $\ldots$ \\
\hline
\end{tabular}

* $1400 \mathrm{MWD}$ is equivalent to $\sim 9 \% \mathrm{U}^{235}$ birnup, or $26,000 \mathrm{MwD} / \mathrm{T}$, or $280 \mathrm{kw}-\mathrm{hr} / \mathrm{cm}^{3}$

Table 18

KRYPTON AND XENON RELEASE DATA FOR CAPSULE GA-309-6

\begin{tabular}{|c|c|c|c|c|c|c|c|c|c|c|}
\hline \multirow[b]{2}{*}{$\begin{array}{l}\text { Sample } \\
\text { Series }\end{array}$} & \multirow[b]{2}{*}{$\begin{array}{c}\text { Date Removed } \\
\text { From GETR }\end{array}$} & \multirow[b]{2}{*}{$\begin{array}{l}\text { Ir radiation } \\
\text { lime* } \\
\text { (MwD) }\end{array}$} & \multirow{2}{*}{$\begin{array}{c}\text { Fuel-compact } \\
\text { Temp. } \\
\left({ }^{\circ} \mathrm{C}\right)\end{array}$} & \multicolumn{7}{|c|}{ Steady-state Release $(\%)$} \\
\hline & & & & $\begin{array}{l}x e^{138} \\
(17 \mathrm{~m})\end{array}$ & $\begin{array}{l}K \mathrm{r}^{87} \\
(78 \mathrm{~m})\end{array}$ & $\begin{array}{l}\mathrm{Kr} \mathrm{r}^{88} \\
(2.8 \mathrm{~h})\end{array}$ & $\begin{array}{l}\mathrm{Kr} \\
85 \mathrm{~m} \\
(4.4 \mathrm{~h})\end{array}$ & $\begin{array}{l}\mathrm{x} \mathrm{e}^{135} \\
(9: 1 \mathrm{~h})\end{array}$ & $\begin{array}{l}X e^{133} \\
(5.3 d)\end{array}$ & $\begin{array}{c}\mathrm{Kr}^{85} \\
(10.3 \mathrm{y})\end{array}$ \\
\hline 8 & $11 / 22 / 60$ & $19 i$ & $1549 . .$. & $\therefore-$ & $\therefore--$ & 0.12 & 0.18 & 0.010 & 0.17 & 0.75 \\
\hline 9 & $12 / 7 / 60$ & 470 & 1865 & --- & 0.28 & 0.37 & 0.51 & 0.031 & 0.64 & 7. 0 \\
\hline 16 & $7 / 20 / 61$ & 1004 & 1616 & $--\cdots$ & 0.63 & 0.54 & 0.93 & 0.19 & 0.87 & 20 \\
\hline 19 & $1 / 27 / 61$ & 1171 & 1746 & - & 1.4 & 1.8 & 2.7 & 0.16 & 2.2 & $\cdots$ \\
\hline 22 & $2 / 3 / 61$ & 1381 & $1750^{\circ}$ & 0.34 & 0.8 & 1.2 & 2.5 & 0.13 & 2.3 & --- \\
\hline 25 & $3 / 25 / 61$ & 1555 & $\ldots-$ &.-- & 0.22 & 0.36 & 0.66 & 0.027 & 0.137 & - \\
\hline
\end{tabular}

$* 1400 \mathrm{MwD}$ is equivalent to $\sim 9 \% \mathrm{U}^{2.35}$ burnup, or $26,000 \mathrm{MwD} / \mathrm{T}$, or $280 \mathrm{kw}-\mathrm{hr} / \mathrm{cm}^{3}$

$\dagger_{\text {Estimated. }}$ 


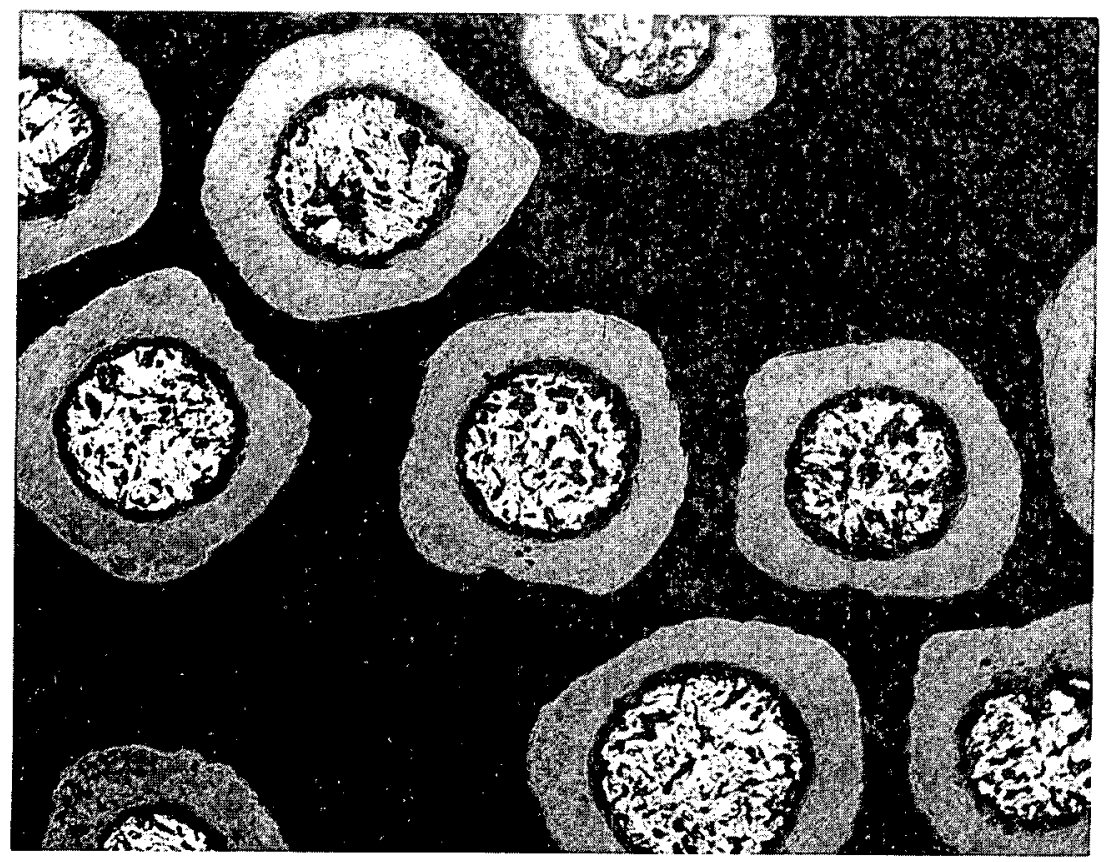

$(75 \times)$

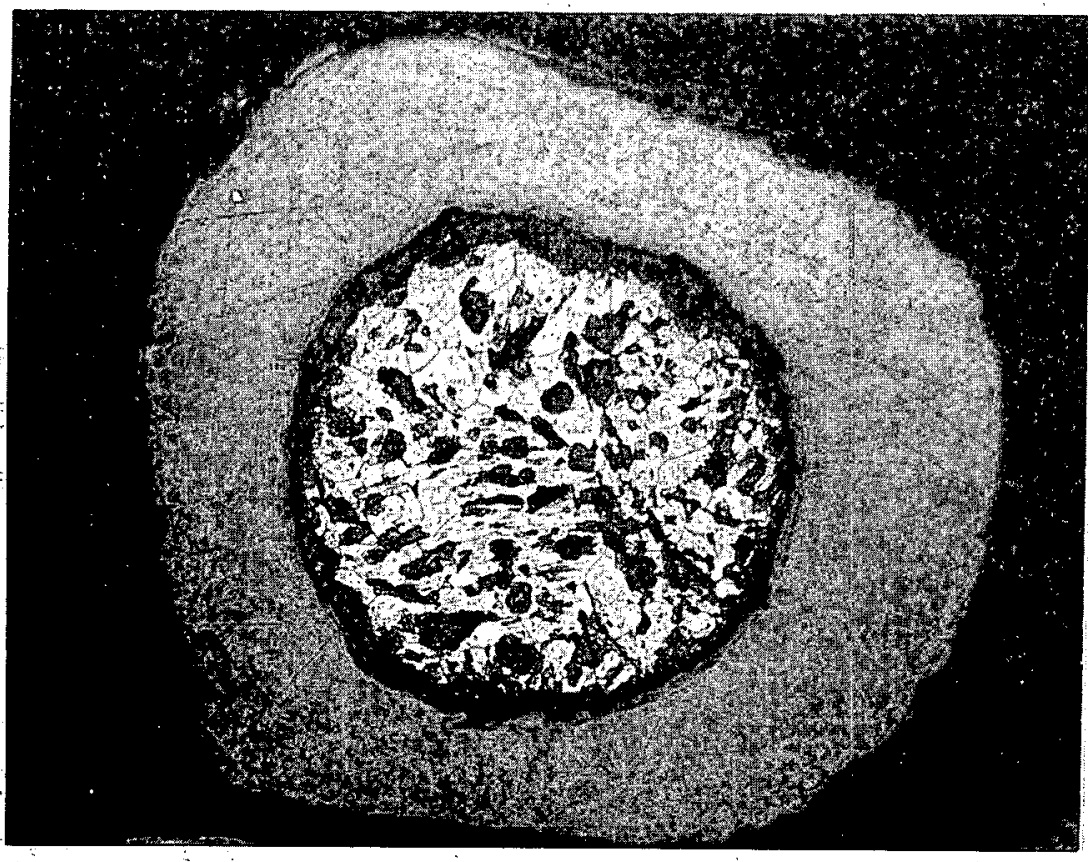

$(200 \times)$

Fig. 52--Pyrolytic-carbon-coated (Th, U) $\mathrm{C}_{2}$ fuel particles prepared for irradiation of capsule GA-309-9; coating was deposited from acetylene at $1400^{\circ} \mathrm{C}$ 


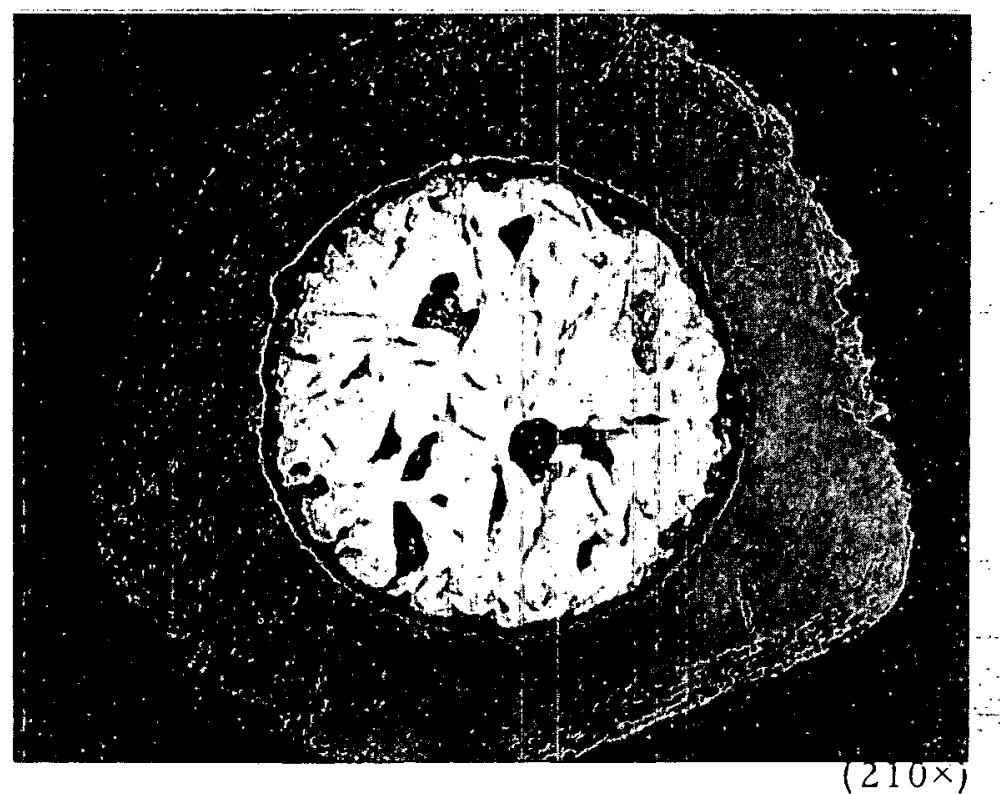

Fig. 53--Pyrolytic-carbon-coated (Th, U) $\mathrm{C}_{2}$ fuel particle typical of those prepared for irradiation of capsule GA-309-8; coating was deposited from methane at $1400^{\circ} \mathrm{C}$

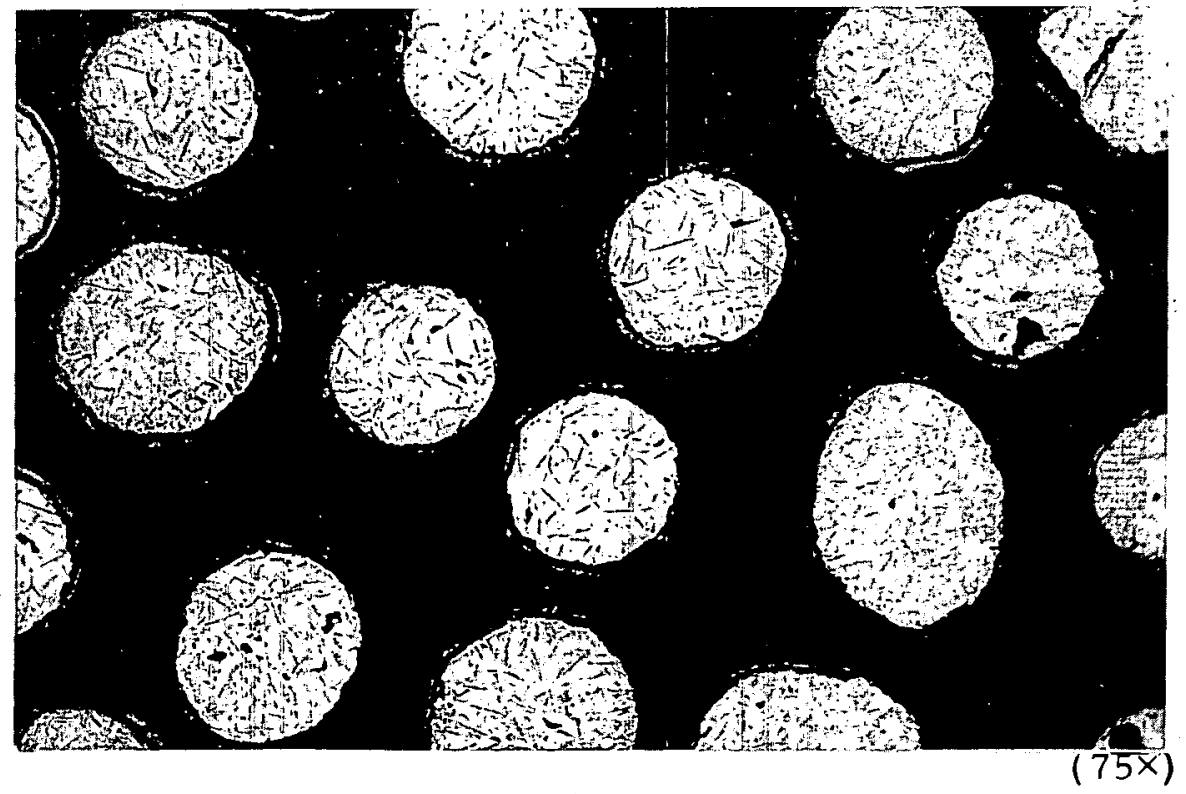

Fig. 54--Thinly coated (Th, U) $\mathrm{C}_{2}$ fuel particles prepareci for ir radiation of capsule GA-309-7; 10- $\mu$ coating deposited from acetylene at $1400^{\circ} \mathrm{C}$ 
-5, and -6 (see Fig. 50), were prepared and subjected to a full burnup irradiation at ambient temperature $\left(<100^{\circ} \mathrm{C}\right)$. The particles were then heated to high temperature in order to generate pressure within the particles, and the fission-gas release was studied.

A compact containing $1 \mathrm{mg}$ of $\mathrm{U}^{235}$ was irradiated in the GETR for one cycle. The sample was placed in the highest thermal-flux $\left(2 \times 10^{14}\right.$ neutrons $/ \mathrm{cm}^{2}-\mathrm{sec}$ ) region of the reactor. A total of $3.5 \times 10^{20}$ nvt was received by the sample, giving a burnup of $20.5 \% \mathrm{U}^{235}$. The compact was allowed to cool for one month, and was then heated to $1000^{\circ} \mathrm{C}$ for $1.5 \mathrm{hr}$ in the fission-product testing furnace. A helium purge over the compact swept the released $\mathrm{Xe}^{133}$ and $\mathrm{Kr}^{85}$ into remote liquid-nitrogen-cooled charcoal traps, where the gases were monitored. The amount of $\mathrm{Xe}^{133}$ released was $0.42 \%$. The temperature was then raised to $1700^{\circ} \mathrm{C}$ and maintained for 2. 79 days. The quantity of $\mathrm{Xe}^{133}$ released was $17.8 \%$. The release of $\mathrm{Kr}^{85}$ was evaluated in the same manner, giving a release value of $18 \%$. To reduce the error in evaluating the fractional release based on the calculated burnup, the compact was thermal-cycled ten times to $2600^{\circ} \mathrm{C}$ for complete removal of $\mathrm{Xe}^{133}$ and $\mathrm{Kr}^{85}$

In order to compare the release of a high-burnup compact with that of unirradiated material, an identical control compact containing $10 \mathrm{mg}$ $\mathrm{U}^{235}$ was irradiated in the General Atomic TRIGA reactor to $10^{13}$ fissions. This compact was then heated to $1700^{\circ} \mathrm{C}$ for $40 \mathrm{hr}$, and the $\mathrm{Xe}{ }^{133}$ release was determined to be $0.5 \%$.

These results indicate that a majority of the coated particles were still intact after the equivalent of a 100\% HTGR burnup (3-yr fuel life). The release curve for $\mathrm{Xe}^{133}$ was similar to that observed for a compact with uncoated particles, which is apparently the behavior that may be expected from particles whose coatings have broken open.

Additional tests of this type are in progress. Various (Th, U) $\mathrm{C}_{2}$ particles with varying coating thicknesses are being investigated. 
OTHER COMPACT STUDIES

$\underline{\text { Additives }}$

Metals that form stable carbides and have low neutron-absorption cross sections were added to the graphite-pitch mixture and hot-pressed at about $2000^{\circ} \mathrm{C}$. By reacting with the graphite during hot-pressing, the metals might act as sintering aids to produce denser compacts, to strengthen the compacts through formation of a network of carbides, and to decrease porosity, thereby giving greater fission-product retentivity.

Silicon, niobium, and zirconium in concentrations from 1 to $40 \mathrm{wt}-\%$ were studied; the results are shown in Table 19 and Fig. 55. Densities

Table 19

PROPERTIES OF COMPACTS PREPARED WITH SILICON, NIOBIUM, AND ZIRCONIUM ADDITIVES*

\begin{tabular}{|c|c|c|c|c|c|}
\hline \multirow[b]{2}{*}{ Additive } & \multirow{2}{*}{$\begin{array}{c}\text { Concentration } \\
(w t-\%)\end{array}$} & \multirow{2}{*}{$\begin{array}{l}\text { Density } \\
\left(\mathrm{g} / \mathrm{cm}^{3}\right)\end{array}$} & \multicolumn{2}{|c|}{ Crushing Strength (psi) } & \multirow[b]{2}{*}{ Permeability } \\
\hline & & & Transverse & Longitudinal & \\
\hline \multirow[t]{7}{*}{ Silicon } & 1 & 1.86 & 6,900 & 4,900 & $4.3 \times 10^{-3}$ \\
\hline & 5 & 1.91 & 5,950 & 6,200 & 3.8 \\
\hline & 10 & 1.97 & 3,900 & 5,400 & 3.5 \\
\hline & 20 & 2.00 & 6,000 & 10,000 & 2.5 \\
\hline & 20 & 1.95 & 8,400 & 5,150 & 7.3 \\
\hline & 30 & 1.98 & --- & --- & --- \\
\hline & 40 & 1.90 & ---- & --- & --- \\
\hline \multirow[t]{4}{*}{ Niobium } & 1 & 1.89 & 5,300 & 8,000 & $7.3 \times 10^{-3}$ \\
\hline & 5 & 2.00 & 5,900 & 5,500 & 4.8 \\
\hline & 10 & 2.07 & 3,350 & 4,500 & 6.6 \\
\hline & 20 & 2.25 & 3,200 & 2,700 & 8.4 \\
\hline \multirow[t]{4}{*}{ Zirconium } & 1 & 1.89 & 2,800 & 2,950 & $7.0 \times 10^{-3}$ \\
\hline & 5 & 1.97 & 4,500 & 3,500 & 12.2 \\
\hline & 10 & 2.04 & 3,300 & 4,000 & 13.5 \\
\hline & 20 & 2.21 & 2,200 & 2,900 & 11.1 \\
\hline None & -- & 1.94 & 5,400 & 6,000 & $5.0 \times 10^{-3}$ \\
\hline
\end{tabular}

* Metal powders added to a mixture of No. 28 graphite and pitch mixture; cold-compacted at 50,000 psi and hot-pressed at 4,500 psi at $\sim 2000^{\circ} \mathrm{C}$; compacts $1 \mathrm{in}$. in diameter by 2 in. long. 


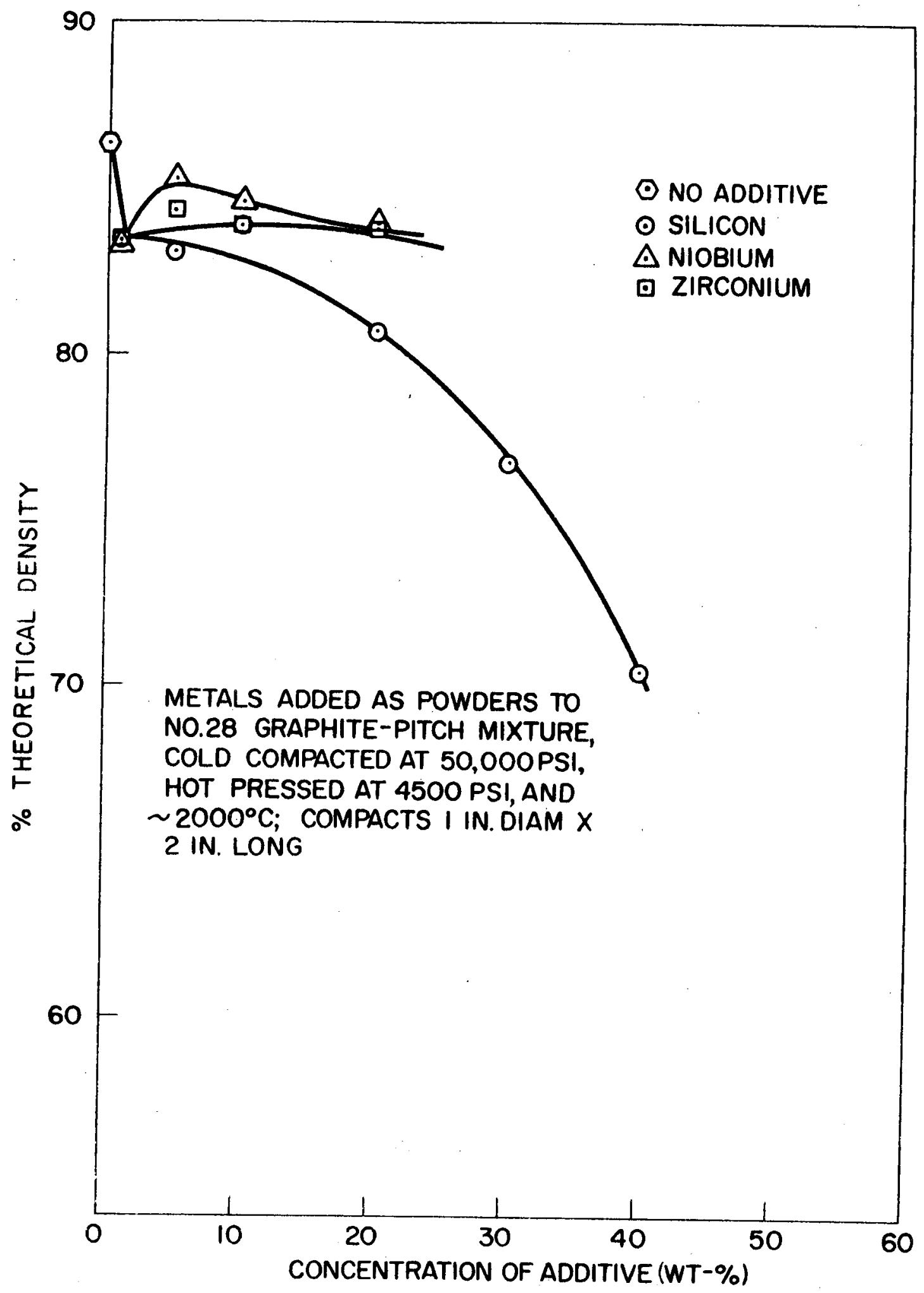

Fig. 55--Variation of compact density with concentration of metallic additive 
lower than those found in control compacts with no additives were noted as the content of each metal reached $1 \%$. The density of the silicon-containing compacts (assuming $\mathrm{SiC}$ formation). continued to decrease with increasing silicon content, but compacts containing zirconium remained about constant at $84 \%$ of theoretical density. Only niobium gave an increase in theoretical density beyond a $1 \%$ concentration, but even this metal did not permit the test compact to regain the density of the compacts without additives.

Strength and permeability data showed considerable scatter, though in two cases with silicon and one with niobium a considerable increase in compact strength was obtained. Three silicon-containing compacts showed slight decreases in permeability.

Graphite-matrix Control-rod Bodies

$\mathrm{B}_{4} \mathrm{C}$ dispersed in graphite has been selected as the control material for the HTGR, and the boron concentration required is predicted to be in the range of 20 to $40 \mathrm{wt}-\%$.

The warm-press and sinter process developed for fuel-compact fabrication was successfully adapted to the preparation of $\mathrm{B}_{4} \mathrm{C}-$ graphite fuel bodies, and compacts containing up to $44 \mathrm{wt}-\%$ boron were produced. Boron loadings and atom ratios are given in Table 20 for 1 -in. -diameter compacts that were warm-pressed at $800^{\circ} \mathrm{C}$ and sintered at $1400^{\circ} \mathrm{C}$. Similar compacts were heated in vacuo for $2 \mathrm{hr}$ at $2000^{\circ} \mathrm{C}$ with no detectable loss of boron.

Table 20

BORON LOADINGS AND ATOM RATIOS OF $\mathrm{B}_{4} \mathrm{C}$-GRAPHITE COMPACTS

\begin{tabular}{c|c|c|c}
\hline $\begin{array}{c}\text { Boron } \\
\text { Loading } \\
(\text { wt }-\%)\end{array}$ & $\begin{array}{c}\text { Compact } \\
\text { Density } \\
\left(\mathrm{g} / \mathrm{cm}^{3}\right)\end{array}$ & $\begin{array}{c}\text { Boron } \\
\text { Loading } \\
\left(\mathrm{g} / \mathrm{cm}^{3}\right)\end{array}$ & $\begin{array}{c}\text { B }_{4} \mathrm{C}: \text { Graphite } \\
\text { Atom Ratio }\end{array}$ \\
\hline 20 & 1.84 & 0.37 & 3.6 \\
30 & 1.81 & 0.55 & 2.1 \\
40 & 1.75 & 0.70 & 1.35 \\
\hline
\end{tabular}


The variation in density with boron content is shown in Fig. 56. Density decreases with increasing boron content, particularly after the boron content exceeds $20 \%$. The annular compacts are less dense than solid ones as a result of friction on the additional die surface during pressing, but higher pressures can be used to compensate for this.

Crushing strength versus boron content is shown in Fig. 57. The exceptionally high strength of the $20 \%$ - and $30 \%$-boron materials is not understood at present, and further studies are in order. (The point shown at $20 \%$ boron concentration in Fig. 57 is an average of five determinations; the points at $0 \%, 30 \%$, and $44 \%$ boron concentration are the average of two to four determinations each; and the point at $40 \%$ boron concentration is a single determination.) If boron carbide really contributes to the strength of the graphite body, this would be an interesting subject to pursue. At this point, ore may conclude that the strength of the fuel matrix graphite is not impaired by boron loading up to $30 \mathrm{wt}-\%$. Beyond this concentration, however, there appears to be a definite decrease in strength.

Four sets of compacts are currently undergoing irradiation testing in the GA-310-5 capsule series. Each capsule contains a set of three compacts, the compacts consisting of 20,30, and $40 \mathrm{wt}-\%$ boron, respectively. The first two capsules are being irradiated for two cycles in the core of the GETR (equivalent to about one-third the exposure lifetime of an HTGR control rod); one at $700^{\circ} \mathrm{F}$ and one at $1200^{\circ} \mathrm{F}$. The second two capsules are being irradiated at the same temperatures, but for six cycles (100\% exposure).

\section{ACKNOWLEDGMENTS}

The author has drawn on the work of many individuals at General Atomic in the preparation of this report. In particular, he would like to aiknowledge the valuable irradiation studies conducted by $W$. Godsin, the fission-product-retention testing of $L$. Zumwalt and E. Anderson, 


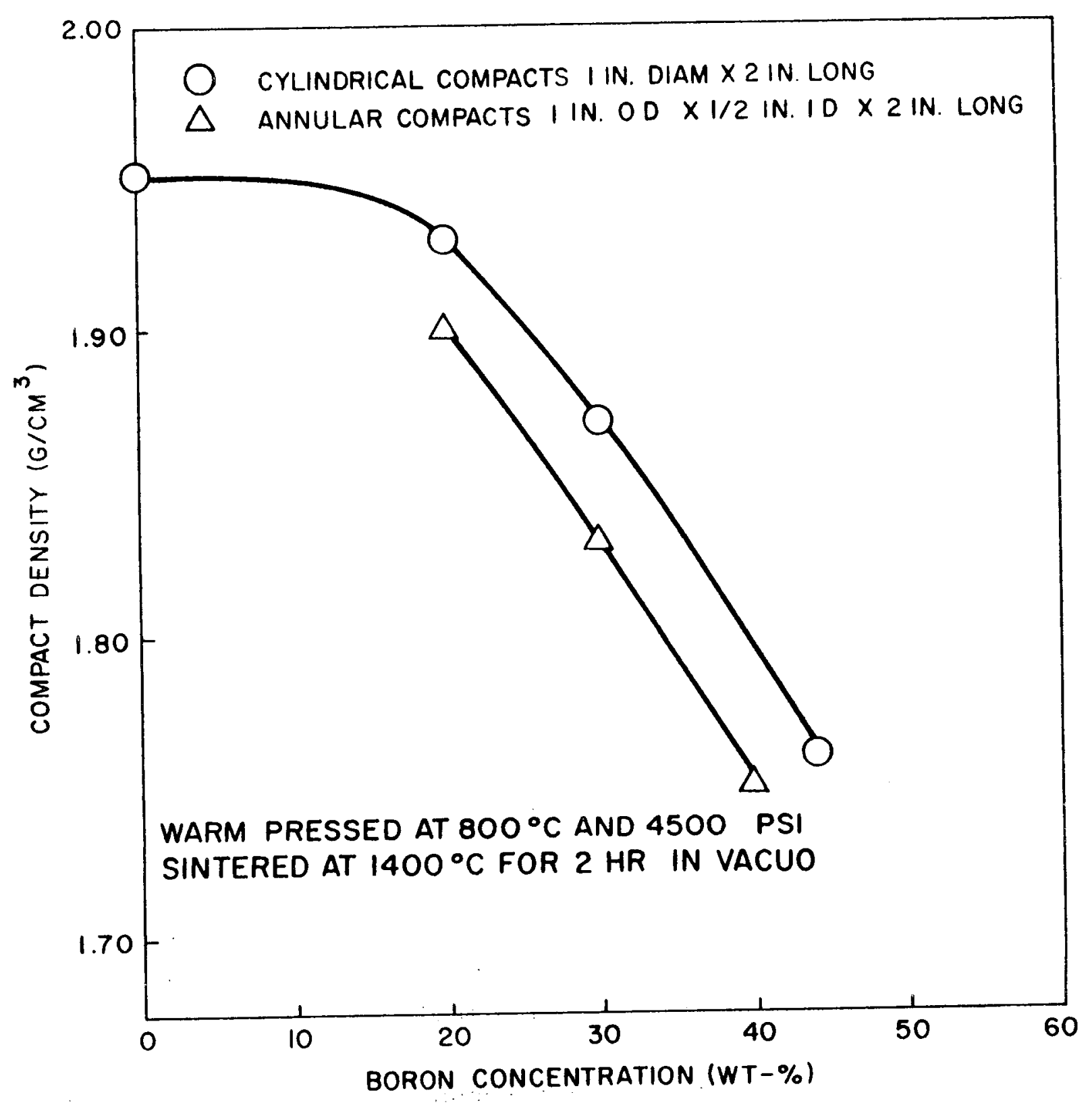

Fig. 56--Density versus boron content for $\mathrm{B}_{4} \mathrm{C}$-graphite control-rod compacts prepared by the warm-press and sinter process 


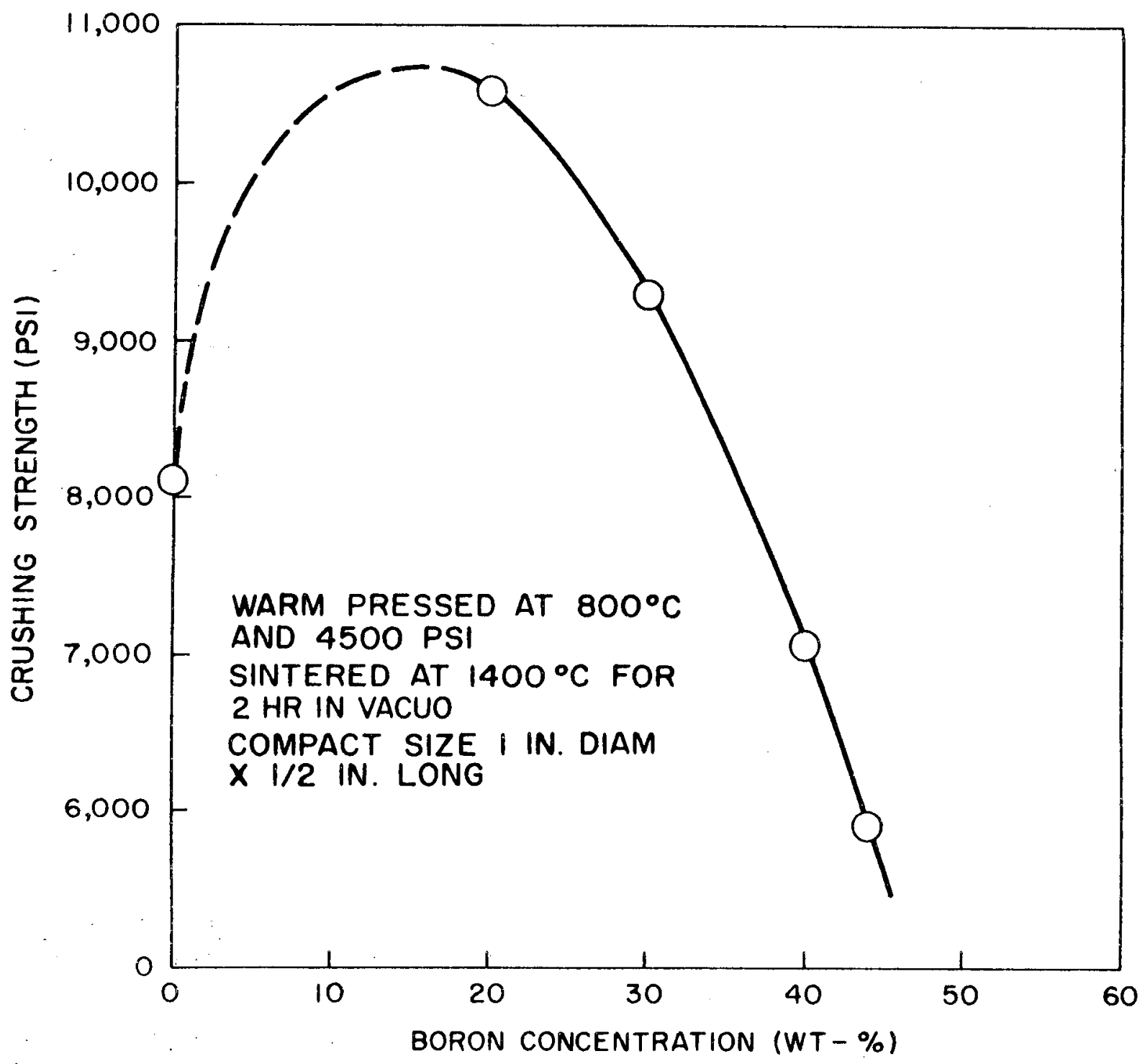

Fig. 57--Crushing strength versus boron content for $\mathrm{B}_{4} \mathrm{C}$ - graphite control-rod compacts prepared by the warm-press and sinter process 
the analytical chemistry development of $A$. Mosen, and the metallographic assistance of D. Menken. Others who contributed to these studies include F. Carpenter, G. Engle, R. Pyle, J. Pontelandolfo, and E. Shoffner.

\section{REFERENCES}

1. Fortescue, P., D. Nicoll, C. Rickard, and D. Rose, "HTGR-Underlying Principles and Design," Nucleonics, Vol. 18, January, 1960; p. 86.

2. Rose, D., The High Temperature, Gas-Cooled, Graphite-Moderated Reactor (HTGR), General Atomic, Report GA-1158, January, 1960.

3. 40-MW(E) Prototype High-temperature Gas-cooled Reactor, Research and Development Program, Quarterly Progress Report for the Period Ending December 31, 1959, General Atomic, Report GA-1235.

4. Harrison, R. J. , Effect of Particle Size on Fission Fragment Damage for Particles of Fissionable Material Dispersed in a Matrix, Battelle Memorial Institute, Report BMI-846 (Del), 1953.

5. Freeman, E. L., et al., "Preparation, Identification and Chemical Properties of the Thorium Silicides," J. Am. Chem. Soc., Vol. 78, 1956, p. 4850.

6. Bowman, M., private communication.

7. Engle, G. B., Reaction-rate Studies of Thorium-Uranium Dicarbides in Moist Air, General Atomic, Report GA-2068, April 11, 1961.

8. Progress on Ceramic Coated Fuel Particles at Battelle, Battelle Memorial Institute, Report BMI-1468, July 12, 1960.

9. Luby, C., Apparatus and Procedure for Coating Thorium-Uranium Carbides with Carbon at $1000^{\circ}$ to $1400^{\circ} \mathrm{C}$, General Atomic, Report GA-2241, May 25, 1961 .

10. Engle, G., Development of Carbon Coating Process for (Th, U) $C_{2}$ Fuel Particles, General Atomic, Report GA-2301, to be published.

11. Goeddel, W., An Apparatus for Measuring the Thermal Conductivity of Graphite at High Temperatures, General Atomic, Report GAMD-1229, January 10, 1959.

12. Goeãdel, W. V., Evaluation of Graphites for HTGR Fuel Elements, General Atomic, Report GAMD-990, October 5, 1959.

13. 40-MW(E) Prototype High-temperature Gas-cooled Reactor, Research and Development Program, Quarterly Progress Report for the Period Ending June 30, 1960, General Atomic, Report GA-1640. 
14. Ibid., Quarterly Progress Report for the Period Ending September 30 , 1960, General Atomic, Report GA-1774.

15. Ibid., Quarterly Progress Report for the Period Ending December 31 , 1960, General Atomic, Report GA-1982.

16. Ibid., Quarterly Progress Report for the Period Ending March 31, 1961, General Atomic, Report GA-2204.

17. Zumwalt, L., and E. Anderson, private communication.

18. Godsin, W. , Temperature Control of Fueled Irradiation Capsules by Variable Conductance, General Atomic, Report GA-1114, February 10, 1960 . 